\title{
WILDLIFE MITIGATION AND RESTORATION FOR GRAND COULEE DAM: BLUE CREEK PROJECT PHASE I
}

\author{
Prepared by: \\ Christopher Merker \\ Upper Columbia United Tribes
}

\author{
Prepared for: \\ U.S. Department of Energy \\ Bonneville Power Administration \\ Division of Fish and Wildlife \\ P.O. Box 3621 \\ Portland, OR 97283-362 1 \\ Project Number 9 1-062 \\ Contract Number DE-BI79-91BP20291
}

APRIL 1993 


\section{TABLE OF CONTENTS}

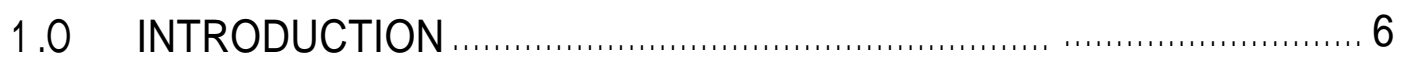

2.0 PROJECT DESCRIPTION …............................................. 9

2.1 Scope of Project ............................................................ 9

2.2 Goal of Project ........................................................... 9

2.3 Site Description........................................................... 11

3.0 METHODS …….................................................................. 12

3.1 General ......................................................................... 12

3. 2 HEP............................................................................. 12

3.3 General Site Descriptions ………………………...... 15

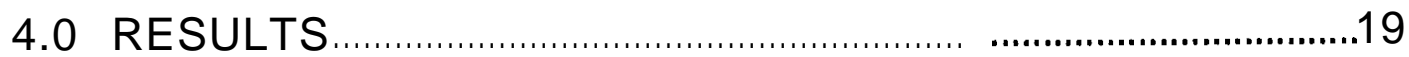

4.1 White-tailed Deer ………………………................... 19

4.2 Sharp-tailed Grouse ..................................................... 20

4.3 Beaver........................................................................ 21

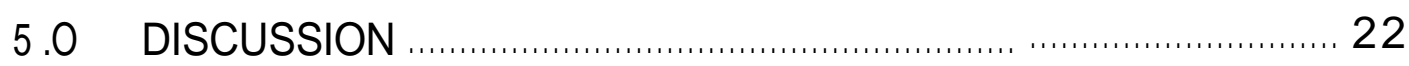

5.1 Species Habitat Management ........................................ 22

5.2 Deer ................................................................................. 22

5.2.1 Commercial Forest Types ................................... 25

5.2.1.1 Ponderosa Pine ..................................... 25

5.2.1.2 Pine-Fir Codominant ............................ 26

5.2.2 Non-Commercial Cover Types ……................... 27

5.2.3 Timing of Treatment........................................... 28

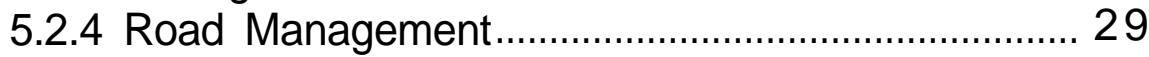

5.3 Sharp-tailed Grouse .................................................... 33

5.4 Beaver................................................................... .34

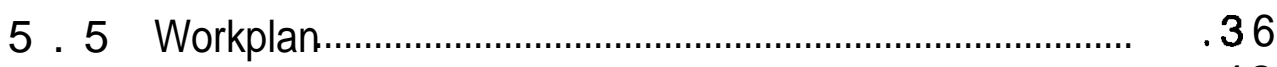

5.6 Budget............................................................................. 42

5.6.1 Trust Fund ................................................................... 43

5.6.2 Project Implementation, Monitoring, 0 \& M .45 5.6.2.1 Baseline Survey...................................... .46

5.6.2.2 Implementation \& Development costs ........................................................ 46

5.6.2.3 Monitoring ………………………....... 48

5.6.2.4 Annual Operations \& Maintenance...48

5.6.2.5 Annual Payment..................................... 48 


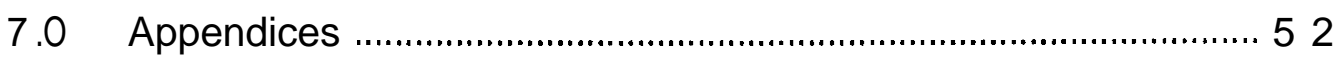

7.1 Project criteria for mitigation plans under NPPC Wildlife Mitigation Rule ..................................... 53

7.2 Spokane Tribe - General Wildlife Goals.................... 63

7.3 Public involvement process certification................65

7.4 Habitat Evaluation Procedures Manual ....................... 74

7.5 Instream habitat improvement plan for Blue Creek........................................................................ 86 


\section{LIST OF TABLES}

Table 1. Grand Coulee habitat unit losses

Table 2. Habitat evaluation team members for Blue Creek Project

Table 3. Habitat types, definitions and map symbols,

Table 4. White-tailed deer HSI by site number and habitat type.

Table 5. White-tailed deer mean $\mathrm{HSI}$ and habitat units by habitat type including estimated habitat units with management.

Table 6. Sharp-tailed grouse HSI and habitat units by habitat type including estimated habitat units with management.

Table 7. Beaver HSI by site number and habitat type

Table 8. Total current HUs and estimated HUs with management for all indicator species

Table 9. Cover types, frequency of types, and acreage used in deer management

Table 10. Spring, ponds and tanks known for Blue Creek Project area.

Table 11. Current and proposed with management road mileage by category

Table 12. Cover types, frequency of types and acreage for sharp-tailed grouse management

Table 13. Cover types, frequency of type and acreage used in beaver management.

Table 14. Payments to trust fund

Table 15. Cost by objective and by year of project 


\section{LIST OF FIGURES}

Figure 1. General location of Blue Creek Wildlife Mitigation Project.

Figure 2. Locations of HEP sites

Figure 3. Cover types on Blue Creek Project

Figure 4. Influences of slope and aspect

Figure 5. Douglas fir value to wintering deer

Figure 6. Deer and elk use response to alteration in cover-forage area ratios.

Figure 7. Impact of roads on deer use

Figure 8. Road management plan.

Figure 9. Sharp-tailed grouse habitat management area

Figure 10. Beaver habitat management area

Figure 11. Existing and proposed hardwood and spring sites 


\subsection{INTRODUCTION}

This report is a recommendation from the Spokane Tribe to the Northwest Power Planning Council (NPPC) for partial mitigation for the extensive wildlife and wildlife habitat losses on the Spokane Indian Reservation caused by the construction of Grand Coulee Dam.

NPPC's interim wildlife goal over the next 7 years for the Columbia hydropower system, is to protect, mitigate and enhance approximately $35 \%$ basin wide of the lost habitat units identified in Table 5 of the 1989 Wildlife Mitigation Rule.

Grand Coulee Dam had the greatest habitat losses of any Dams listed in Table 5 of the Wildlife Rule. Those losses were excerpted from the Wildlife Rule and are shown below. Also shown are that portion of the losses that occurred on the Spokane Indian Reservation (Washington Department of Wildlife 1986).

Table 1. Grand Coulee Habitat Unit Losses

\begin{tabular}{lccc} 
& Total Habitat Units & & Spo kane Tribe \\
\cline { 2 - 2 } Species & $\mathbf{( H . U . )}$ & & $\mathbf{( H . U . )}$ \\
\hline Sage Grouse & $-2,746$ & 0 \\
Sharp-tailed Grouse & $-32,723$ & $-2,609$ \\
Ruffed Grouse & $-16,502$ & -974 \\
Mourning Dove & $-9,316$ & -653 \\
Mule Deer & $-27,133$ & $-1,087$ \\
White-tailed Deer & $-21,362$ & $-1,180$ \\
Riparian Forest & $-1,632$ & -176 \\
Riparian Shrub & $\mathbf{- 2 7}$ & NA \\
Canada Goose Nest Sites & $\mathbf{- 7 4}$ & $\mathbf{- 2 0}$
\end{tabular}

An extensive public involvement process was followed to formulate and prioritize goals to restore this lost habitat.

(1) First, the Tribal Council, Tribal Fish and Wildlife Committee, and all members of the Spokane Tribe (via mailing questionnaires) were consulted to establish priority species and habitats.

(2) Second, the mitigation goals and plans were coordinated with the Spokane Tribes' Timber and Range Management Plans, and 1990 Integrated Resource Management Plan, via the appropriate personnel from the Bureau of Indian Affairs Spokane Agency. This will insure 
that conflicts between wildlife, timber and range management will be minimized. In fact, it has been agreed that lands, described in this proposal (to be set aside for wildlife), will be managed exclusively for wildlife.

(3) Third, we rigorously applied the criteria set forth in the Power Council's 1989 Wildlife Rule in establishing mitigation goals and designing specific projects to implement these goals. The criteria are specifically addressed in a separate section of this report (i.e., Appendix 7.1). After reading that section, we believe that Council members will agree that the mitigation proposed in this report by the Spokane Tribe complies with all of the Council's criteria. For example, this project is on tribal land, so it does not require acquisition of additional public lands. It protects one of the few remaining riparian areas left on the Spokane Reservation and benefits both resident fish and wildlife. It is in a blocked area that formerly had salmon and steelhead runs that were eliminated by a federal hydroelectric project.

(4) Fourth, we identified four goals that would mitigate for $100 \%$ of the Spokane Tribe's wildlife losses. We then conducted a cost -vbenefit analysis (See Merker and Scholz, 1990) to determine which of the goals was the least costly in terms of amount of dollars per habitat unit gained. We ranked the lowest cost per habitat unit gained as the Spokane Tribe's number 1 project. We then developed an implementation plan to achieve this number 1 goal.

(5) Fifth, we subjected the four ranked goals and implementation plan to extensive public review both on and off the reservation. Two public meetings, advertised in the newspaper, were held on the reservation, at Wellpinit (on the east end) and the Westside Community Center (on the West End). We participated with the Washington Department of Wildlife and Colville Tribe at a meeting for county and local government officials held at the Spokane International Airport where we outlined our goals and implementation plan for goal number 1. We also participated in public meetings held in Davenport, Colville and Kettle Falls, WA which were designed to allow for public comment. We accepted written comments. We took all comments received into account when writing this document. A summary of our public review process and our answers to specific comments is included in Appendix 7.3. 
(6) In April 1990 the tribe submitted a proposal for the number one goal as identified in the above process (Merker and Scholz, 1990). This proposal discussed specific goals and estimated costs. This proposal was then used to explain the projects to members of the wildlife mitigation project ranking process. This began with the Implementation Planning Process (IPP) as designed by the Columbia Basin Fish and Wildlife Authority (CBFWA) and Bonneville Power Administration (BPA). In December 1990 BPA Scoping Group (SG) ranked 27 projects submitted from three northwest states for wildlife mitigation. Blue Creek scored 32 points placing it number four in importance. BPA Policy Review Group (PRG) then reviewed and discussed the process, and ultimately accepted the SG ranking without changes. Planning money was then made available to expand the scope of project design from the 1990 proposal. This phase began in August 1991 and is detailed in this document.

The Spokane Tribe's highest priority goal is:

Protect and develop 2631 habitat units of big game winter range and riparian shrub habitats on 5400 acres of Spokane Tribal trust land, to mitigate losses resulting from reservoir inundation due to Grand Coulee Dam. Species benefitting include: white-tailed deer, mule deer, elk, Merriam's turkey, ruffed, blue and sharp-tailed grouse, white-headed woodpecker, Cooper's hawk, yellow warbler, beaver, moose, yellow-billed cuckoo, black bear, waterfowl, pine grosbeak, golden and bald eagle, and puma.

The remainder of this report is a plan to implement this top priority goal. This report is the advanced design and outlines specific objectives and tasks required to implement the goal. Scheduling of these objectives and tasks by project year, along with an annual and total budget is also reported. A funding mechanism, requiring the establishment of a trust fund, is described. It should be emphasized that this entire project is on land owned by the Spokane Tribe, and will require a lease agreement between BPA and the tribe. 


\subsection{PROJ ECT DESCRIPTION}

\subsection{Scope of Project}

The construction of Grand Coulee Dam inundated 3,900 acres of land and destroyed 6,699 wildlife units on the Spokane Indian Reservation (WDW 1986). In addition, extreme fluctuations in water levels destroyed riparian habitat and precluded the re-establishment of riparian plant communities. Also, operation of the reservoir for power generation and flood control has caused (and continues to cause) extensive sloughing (i.e., land slides). This has resulted in additional lost wildlife habitat, which is not counted in the above figures. The largest landslides reported on Lake Roosevelt occured on the Spokane Indian Reservation along 10 miles of former Spokane River. Finally, habitat loss occurred 50 years ago and cumulative wildlife losses have been extensive.

The Tribe identified four goals, which would require improvements on 10,590 acres of current reservation land, to gain back the lost habitat units (Merker and Scholz, 1990). Since existing land is relatively less suited for producing wildlife than the land that was lost, it will require habitat enhancement on greater than 3900 acres to fully mitigate the loss. An oversight committee composed of representatives of the Washington Department of Wildlife, Spokane Tribe, Colville Tribe, U.S. Fish and Wildlife Service, BOR, and PNUCC recommended that wildlife improvement on 10,590 acres would be reasonable mitigation for wildlife habitat losses on the Spokane Indian Reservation (WDW 1986). Here we propose that BPA will lease 5400 of these required acres from the Spokane Tribe, with funds to be put in a trust account. Interest from the trust would be used to (1) improve the condition of this land for wildlife, (2) operate and maintain the leased property for the benefit of wildlife, (3) monitor improvement to wildlife populations, and (4) reimburse the Spokane Tribe for foregone timber harvest on this land. Any remaining interest generated will be used to finance additional wildlife mitigation on the reservation which would be applied to the hydropower debt.

\subsection{Goal of Project}

The primary goal of this project is to increase survival and reproductive rates of white-tailed deer, a Habitat Evaluation Procedure indicator species, as well as mule deer. This will be done by improving 5,400 acres of winter range, primary for deer benefits. A total of 2,267 of deer habitat units were lost when Grand Coulee Reservoir flooded 
reservation lands. Additionally the lease would enhance habitat units for beaver and sharp tailed grouse, the other indicator species.

White-tailed deer were selected as the primary indicator species due to their historical and present importance to the tribe. They are a species of special concern to the Spokane Tribe because of their importance for subsistence. Subsistence hunting and fishing is an important supplement to family income for members of the Spokane Tribe.

According to a survey conducted by Brittingham (1986), $56 \%$ of tribal hunters did not get any deer, and the average of those who did was 1.2 deer per household for an estimated total harvest of 167 deer. In 1986, a winter helicopter survey of the Spokane Reservation estimated the deer population to be 482-964, and with an annual production of 196418 new fawns. Assuming a minimum level of annual fawn production (196 deer-year), current harvest levels (167 deer/year) are about equivalent to fawn production. A 1989 winter helicopter survey estimated 117 to 391 deer on the entire reservation, indicating a decline in the population (McLanahan et al. 1989). Each of the four mitigation goals for the Spokane Indian Reservation were designed to protect and improve the habitat types that were destroyed by the building of Grand Coulee Dam. They include enhancement of deer winter range and riparian fawning habitat. Thus, this project is important to the economic well being of the Spokane Tribe.

A second benefit of the proposed habitat enhancement is improvement in both species and habitat diversity on the reservation. We are proposing to expand an entire community (quaking aspen), enhance another (riparian), add the old growth age class to two other communities (ponderosa pine and mixed conifer) and enhance a shrub steppe community. Sharp tailed grouse suffered the highest habitat losses of any indicator species on the reservation owing to construction of Coulee Dam. Opportunities exist for sharp-tail restoration on part of the proposed lease. Ruffed grouse will benefit due to riparian and deciduous forest improvements within the conifer forest type. Salt (1957) looked at six vegetation types and associated bird biomass. He found that moist-site aspen supported three times the biomass of other habitat types. Conifer forest had lower complexity and species diversity. Not only deer but the expanding elk population will benefit. Both deer and elk prefer aspen/riparian communities over other habitats in summer and fall (DeByle 1985). Diversity in the conifer types will be increased through a program of using silviculture to increase coverage of older age classes (mature and old growth). Selective thinning is a useful tool for this, but 
it must be done with big game cover requirements in mind. Older conifer classes will benefit most all raptors including goshawk, and bald and golden eagles. Most cavity resting birds prefer older age classes. Beaver were included as the final indicator species. Management to increase their number was desirable due to their beneficial activities in the environment, such as pool creation.

\subsection{Site Description}

The Spokane Indian Reservation is in Stevens County in northeast Washington State (Figure 1). Summers are warm and dry. The average daily maximum temperature is $82^{\circ} \mathrm{F}$, and $40 \%$ of the annual precipitation of 15 inches falls from April to September. Winters are cold and snowy, with average daily minimum temperature of $21^{\circ} \mathrm{F}$. The project area is composed of two general land forms. "River Breaks Zone" as its name implies is fairly steep, with exposed basalt, scattered trees and shrub cover, formed by and above the former Spokane River at elevation 1290' MSL. "Commercial Forest Zone" is above the River Breaks. Soils here are deeper and topography is less steep resulting in dense tree cover, primarily Ponderosa Pine. This zone is just south of the Huckleberry Mountain Range. Which is thickly forested and averages 4500' MSL. These elevational differences in close proximity are one reason the project is important to wintering deer. 


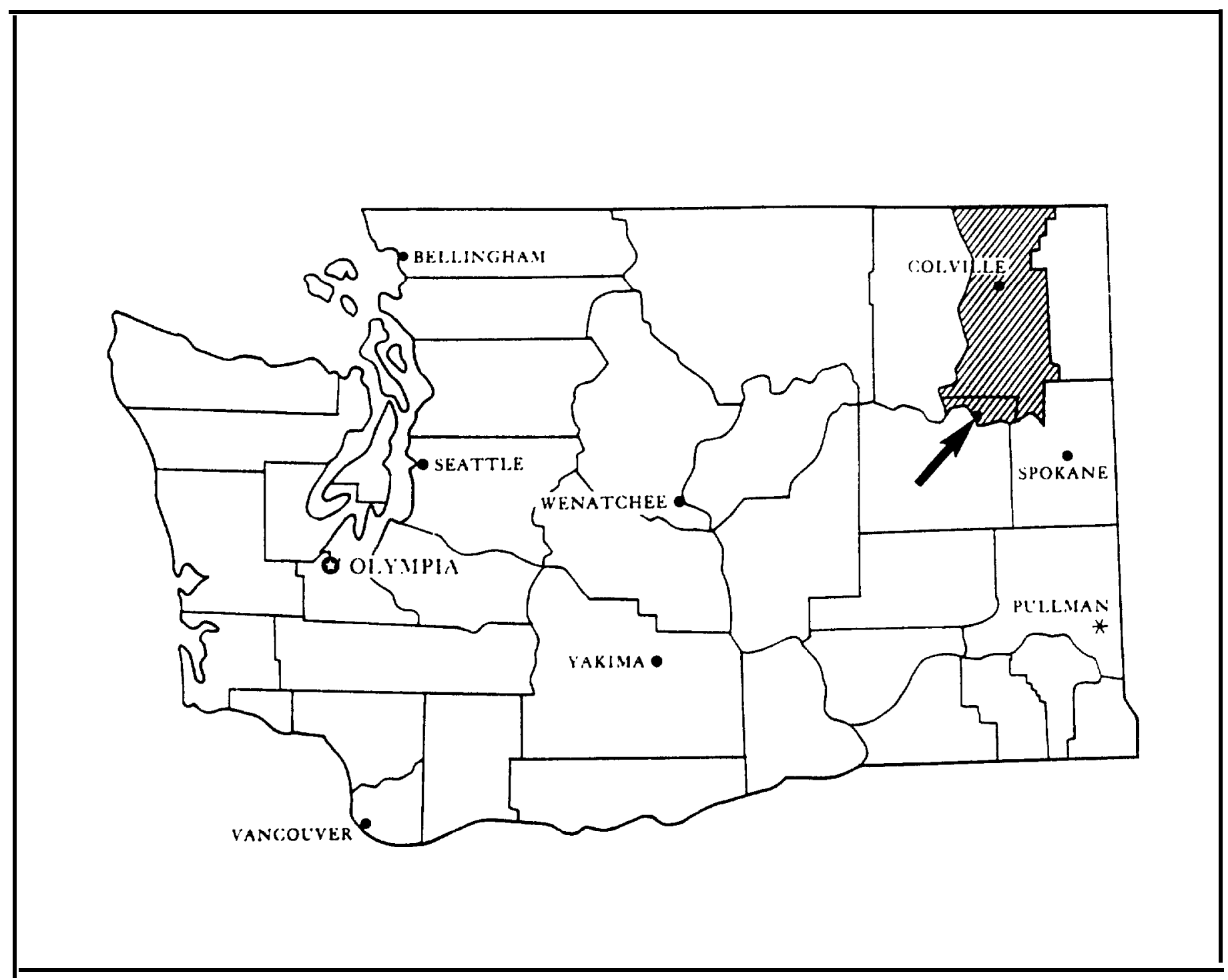

Figure 1. General location of Blue Creek Wildlife Mitigation Project 


\subsection{METHODS}

\subsection{General}

Habitat Evaluation Procedures (HEP) were applied to measure the baseline condition. HEP was the standard loss estimator in all hydro loss statements submitted to the NPPC. BPA required its use on a project specific basis for increased detail and accuracy on projects accepted into the advance design phase.

The Bureau of Indian Affairs (BPA) at Spokane Agency-Wellpinit provided Geographic Information System (GIS) maps and tabular data regarding classification of habitat types within the project boundaries. Habitats were stratified into broad associations by each of the four indicator species. This allowed the estimation of baseline Habitat Units (HUs) and was the basis of future management objectives.

Polygons smaller than 2 acres are not identified in the GIS database. During field work however we noted many "micro-habitats" that were of importance, such as spring or wetland sites and hardwood stands. We mapped all such sites and incorporated them into the management plan.

BIA Forestry Branch personnel were interviewed as to the feasibility of specific management practices. Their comments and knowledge guided management suggestions, estimates of success and costs.

A geomorphological study of the Blue Creek stream profile was conducted by Geology Department personnel at Eastern Washington University. Purpose was to identify best, most stable sites for potential pool creation. This effort was coordinated with Lake Roosevelt Rainbow Trout Habitat/Passage Improvement (BPA Project \# 90-18). Our primary emphasis was to create riparian pool habitat for wildlife, while tributary inventory purpose was to enhance lake-run salmonids. Coordination of efforts will yield dual purpose optimum fish and wildlife benefits.

\subsection{Habitat Evaluation Procedure (HEP)}

The objective of the Habitat Evaluation Procedures conducted on the Blue Creek site was to rate the quality of lands being considered for easement and management as mitigation for losses to wildlife due to damages caused by construction of Grand Coulee Dam. The product of the baseline survey will determine the number of "Habitat Units" $(1$ H.U. $=1$ 
acre of optimum habitat, or e.g. 2 acres of habitat rated at 0.5 ) currently available for individual indicator species, and the amount that will become available with management. Three indicator species were used to determine the habitat quality rating and available habitat units. They were sharp-tailed grouse, white-tailed deer, and beaver. Beaver were not an original indicator species (See WDW 1986). However, they were included here as it was felt they represented both ruffed grouse and riparian forest/shrub habitats.

An interdisciplinary evaluation team was assembled (see Table 2 below). A Habitat Evaluation Procedures Manual was created to aid the team in rating the quality of the habitat. This manual provided the team with Habitat Suitability Models which described life requisites for each indicator species (see Appendix 7.4 for models). This enabled the team to derive a number value between $0.0-1.0$ corresponding to the quality of the habitat, i.e. the habitat suitability index (HSI). The team conducted the site surveys and collected data on habitat type, quantity, quality, and wildlife use under existing conditions (Figure 2).

Table 2. Habitat Evaluation Team Members for Blue Creek Project.

\section{NAME}

Chris Merker

Ronald Peters

Peter Paquet

Paul Ashely

Ted Hensold

JoJo McCrea
AFFILIATION/REPRESENTING

Upper Columbia United Tribes/Spokane Tribe

Upper Columbia United Tribes/Spokane Tribe

Northwest Power Planning Council

Washington Department of Wildlife

Bureau of Indian Affairs/Spokane Tribe

Spokane Tribal Wildlife Committee Member

Using the BIA Forestry Branch Description of habitat types on the reservation, the following 14 types were identified within the project area. In general, all forests are considered to be unevenaged stands with at least three size classes intermixed. Table 3 and Figure 3 list and illustrate these types. 


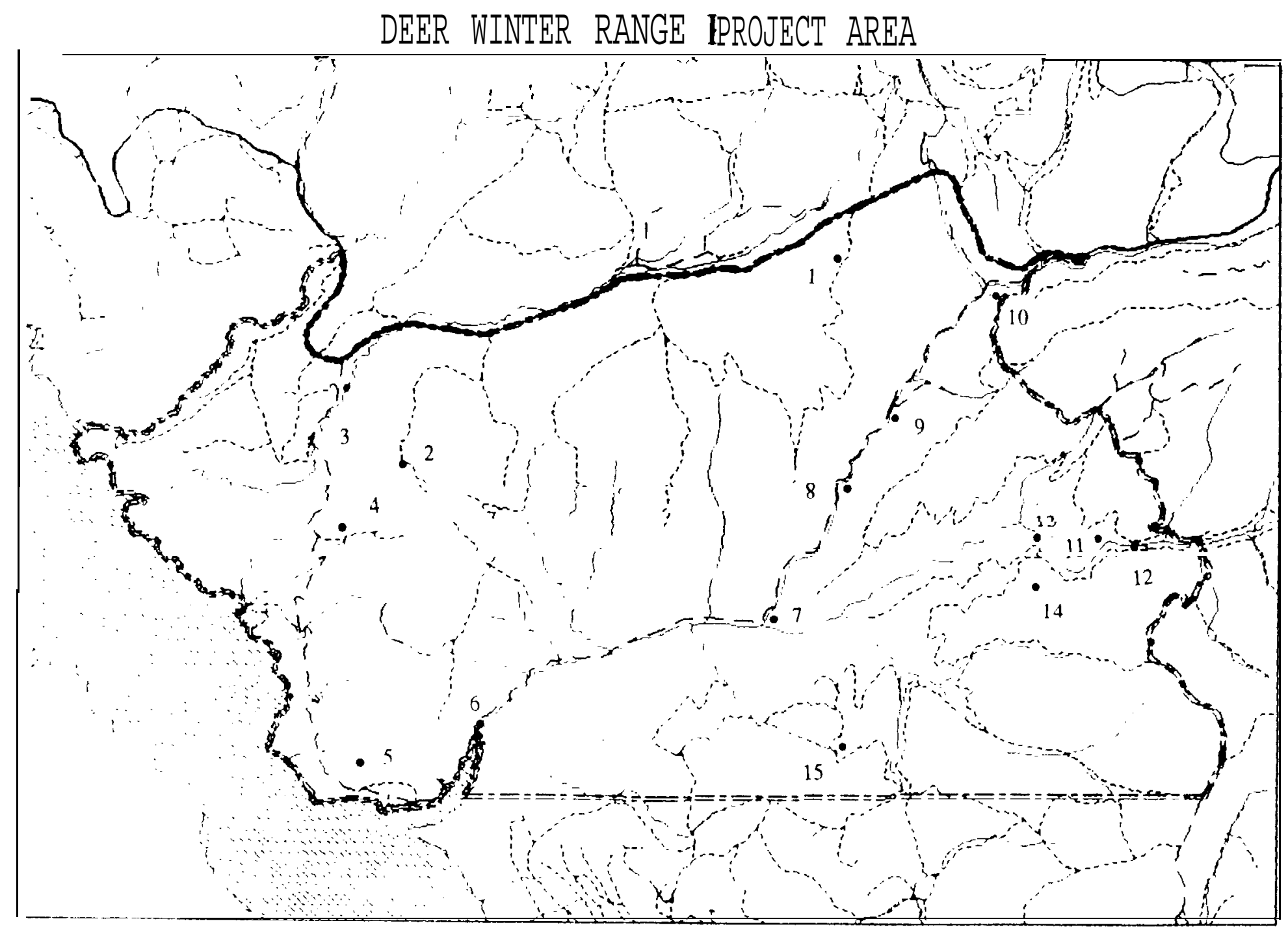

Figure 2. Locations of Blue Creek HEP sites 
DEER HINTER RANGE FOREST CONER TYPES

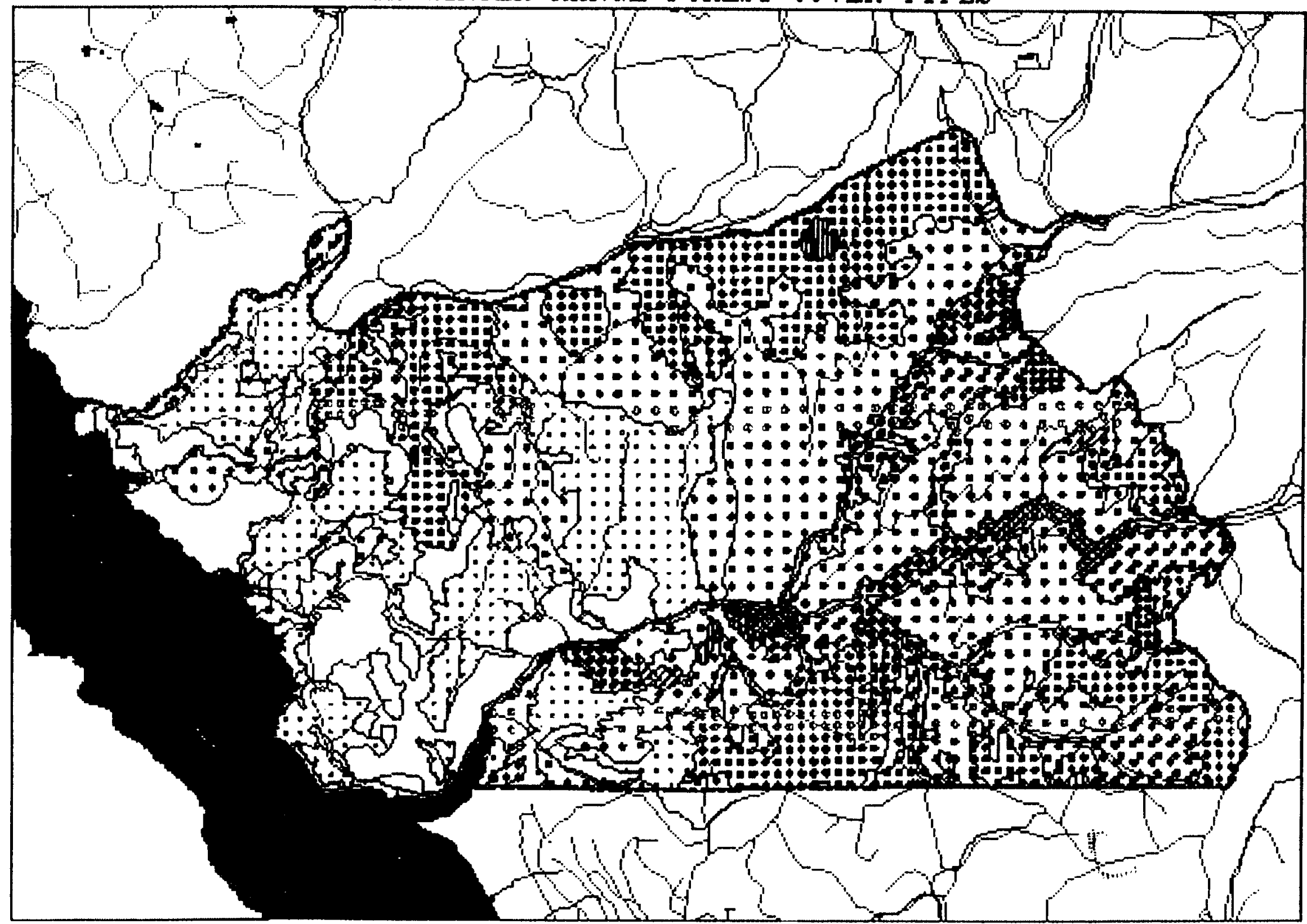

Figure 3. Cover types on Blue Creek project 
Table 3. Habitat types, definitions and map symbols, Blue Creek Project

1) (R)

RIPARIAN-Riparian vegetation composed of grass, forbs, and shrub and tree species, in conjunction with surface water or waterways.

2) $(\mathrm{H})$

HARDWOOD FOREST-Stands composed of of hardwood tree species, not necessarily in conjunction with surface water.

3) (N) NON-COMMERCIAL FOREST LAND-Conifer vegetation which has not attained commercial size or stocking due to site limitations.

4) (S) SURFACE WATER-Ponds, rivers, lakes, and reservoirs.

5) (O) OUTCROP-Rock outcrop, scree and talus.

6) (MC3) MIXED CONIFER STOCKING DENSITY MEDIUM-Forests composed of all combinations of conifers, with canopy crown closure 41 to 70 percent.

7) (PP1) PONDEROSA PINE STOCKING DENSITY SCATTERED-Forests in which ponderosa pine occupies more than $75 \%$ of the canopy area, with canopy crown closure less than 11 percent.

8) (PP2) PONDEROSA PINE STOCKING DENSITY LIGHT-Forests in which ponderosa pine occupies more than $75 \%$ of the canopy area, with canopy crown closure between 11 and 40 percent.

9) (PP3) PONDEROSA PINE STOCKING DENSITY MEDIUM-Forests in which ponderosa pine occupies more than $75 \%$ of the canopy area, with canopy crown closure between 41 and 70 percent.

10 ) (PP4) PONDEROSA PINE STOCKING DENSITY FULL-Forests in which ponderosa pine occupies more than $75 \%$ of the canopy area, with canopy crown closure between 71 and 100 percent. 
11 ) (PF1) PINE/FIR STOCKING DENSITY SCATTERED-Forests in which Douglas-fir constitutes $2575 \%$ of the canopy area and ponderosa pine the majority of the remainder, with canopy crown closure less than 11 percent.

12) (PF2)

PINE/FIR STOCKING DENSITY LIGHT-Forests in which Douglas-fir constitutes $25-75 \%$ of the canopy area and ponderosa pine the majority of the remainder, with canopy crown closure between 11 and 40 percent.

13) (PF3)

PINE/FIR STOCKING DENSITY MEDIUM-Forests in which Douglas-fir constitutes $2575 \%$ of the canopy area and ponderosa pine the majority of the remainder, with canopy crown closure between 41 and 70 percent.

14) (PF4) PINE FIR STOCKING DENSITY FULL-Forests in which Douglas-fir constitutes $25-75 \%$ of the canopy area and ponderosa pine the majority of the remainder, with canopy crown closure between 71 and 100 percent.

Following the indicator species selection in conjunction with habitat delineation as above, we selected study sites. Site selection was based on both importance to the indicator species, and the relative abundance of a given habitat type within the project area.

\subsection{Site Descriptions}

See Figure 2 for locations of sites below.

All sites were marked by affixing to trees aluminum plates reading, "UCUT HEP Site \#."

\section{Site \#1}

Site one is a PP3 habitat type. Only one HEP model, the white-tailed deer, was used at this site. It is located on a fire control road about $1 / 2$ mile from the main paved highway. This road is the first road west of the east entrance to Blue Creek. Marker plate is on a pine on the west side of the road.

\section{Site \#2.}

The general location is about one mile south on the last road before the main Blue Creek road exits the project area by Sand Creek. This site is comprised of two subsites. The first, is a open wet meadow $(\mathrm{H})$ surrounded by aspen trees. The second (PP1 habitat type), is marked by 
two ancient rock cairns approximately 200 yards south on the road and then 75 yards west. The white-tailed deer and sharp-tailed grouse models were used at the site. Marker plate is on a pine just south of the road bifurcation immediately north of the meadow.

\section{Site \#3}

Site \#3 (PP3) is on the north Blue Creek road near Sand Creek about 0.5 mile from the northwest entrance. The only model used here was the white-tailed deer model. The marker is on the east side of the road.

\section{Site \#4}

Site \#4 (PPI) is about 1 mile from site \#3 on the same road. Site \#4 is 40 paces up a skid trail south from the marker plate on the south side of the road. Two models were used here, the white-tailed deer and sharp-tailed grouse.

\section{Site \#5}

This site $(\mathrm{N}+\mathrm{O})$ is on a broad bench north of the confluence of Blue Creek and Lake Roosevelt. It is on the same road as site \#4 and about a mile farther down the road. It is predominantly shrub steppe. Only one model was used here, sharp-tailed grouse, and was applied to subsites $5 \mathrm{~A}-5 \mathrm{H}$. Marker plate is on a ponderosa pine in the middle of the bench.

\section{S i t e \#5A-\#5D}

These subsites are defined by a single transect line beginning at the aspen tree clone. Each site is 30 feet from each other in a northerly direction, toward the marker plate.

\section{Site \#5E}

Subsite $5 E$ is located approximately 100 feet from subsite $D$ in a northwesterly direction.

\section{S it e \#5F-5H}

These sites are located on the hillside approximately 200 feet from site $5 \mathrm{E}$. Site $5 \mathrm{~F}$ is found on the south facing slope on a sandy slope. Site $5 G$ is located down the hill in the middle of the draw about 100 feet from site 6 in a easterly direction. Site $5 \mathrm{H}$ is located on the north slope about 100 feet east of site seven.

\section{Site \#6}

This site is at the confluence of Blue Creek and Lake Roosevelt. Marker plate is on a large pine north of the creek and bay confluence. 


\section{Site \#6A}

This site (PP52) is at the confluence of Blue Creek and the Spokane Arm of Lake Roosevelt. It is found on the south side of the creek approximately 200 yards from the confluence on a north facing slope. The area is influenced by roads and other recreational activity. Some evidence of cattle grazing was found in the area. White-tailed Deer was the only $\mathrm{HSI}$ calculated here.

\section{Site \#6B}

This site $(\mathrm{N})$ is on the north side of the creek approximately 200 yards from the confluence on a south facing slope. The area is impacted by roads and cattle. Recreational activity may also influence the wildlife potential of the area. White-tailed deer was the only $\mathrm{HSI}$ calculated here.

\section{Site \#7}

The site contained (R) and (PF3) and is located at the confluence of Oyachen Creek and Blue Creek. It is heavily influenced by the road, which is the main cause of disturbance in the area. Some cattle activity was noted. Beaver was the model used in the riparian area. In the adjacent PF3 habitat type immediately to the south on a north aspect, white-tailed deer $\mathrm{HSI}$ was calculated. Marker was attached to an alder tree south of the road.

\section{Site \#8}

Site \#8 (R) is located northeast along the road from previous site. The HEP sample was taken on the road side of Blue Creek. The road influences the wildlife potential. A marker plate was nailed to a downed log on the creek side of the road. Beaver HSls were calculated. Some cattle activity was noted in the area.

\section{Site \#9}

This site $(R)$ is located along the Blue Creek campground road where there are a series of beaver ponds next to the road. Sightings of two beaver were noted along with noticeable construction and repair of dams, and cutting of trees and shrubs in the adjacent forest. Beaver HSI only was conducted here. Marker plate is on a pine across the creek from the road.

\section{Site \#IO}

This site (MC3) is located on Elijah Road approximately 300 yards south of Blue Creek. The aspect is north and the major cover type is mixed pine and fir. Cattle and roads may limit the wildlife potential. White- 
tailed deer $\mathrm{HSI}$ only was conducted. Marker plate is on a fir at the road turn-out.

\section{S ite \#II}

To get to site \#II (PF3) you turn just before Elijah Road goes over Oyachen Creek. Move down road approximately 0.15 miles where a skid trail follows along the creek bottom. The site is 600 feet down the skid trail. White-tailed deer HSI was calculated here. Marker is on a fir at the edge of the riparian zone.

\section{Site \#12}

Site \#IO (PF2 and R) is located at the intersection of Elijah Road and Oyachen Creek. The site is approximately 150 yards downstream from the culvert where Oyachen Creek flows under the road. Heavy grazing activity was noted at this site. The cattle had destabilized the banks of the creek and cattle feces was noted in the creek. The road influences the wildlife potential in the area, but one ruffed grouse was seen in the area. White-tailed deer and beaver HSls were calculated at this site. Marker is on a fir at confluence of road and a skid trail.

\section{Sit e \#13}

The site (PF2) is a north facing slope approximately 1.5 miles down the road that follows the upper south side of Oyachen Creek. The main cover type is pine/fir mix with a shrub_(Ceanothus) understory. Cattle and roads influence the wildlife potential of the area. White-tailed deer $\mathrm{HSI}$ only was conducted. Marker is on a conifer north of the road.

\section{Sit e \#14}

This site (PP2) is just across the road, up and over the hill from site 13 about 100 yards. It is a south facing slope comprised mainly of light density ponderosa pine and bunch grasses. Some small forbs and shrubs are available for wildlife use but in small quantities. White-tailed deer HSI only was conducted. Marker is on a large pine at the top of a rise, and faces north.

\section{Sit e \#15}

This site (PF2) was marked with a location plate on a pine on the west side of the road. It is located about 1.5 miles from site 14 on the same road which follows the southeast side of Oyachen Creek. It is a north facing slope with a pine-fir overstory and a bitterbrush understory. White-tailed deer $\mathrm{HSI}$ only was conducted. 


\subsection{RESULTS}

Following collection of field data, Habitat Suitability Indicies (HSI) were calculated from models, and multiplied by acres within habitat type be site. The resulting Habitat Units are presented by indicator species in the following tables. This is the baseline, or current, H.U.s for the project area. In addition, a projected estimate of HSI and H.U.s "with management" are presented. See Section 5.0 Discussion for detailed explanation of limiting factors that will be targeted under a management plan.

\subsection{White-tailed Deer}

According to the model the major limiting factor for white-tailed deer on the Blue Creek Project area is the average miles of roads per square mile. HSI scores are low for all habitats due to influence of roads (Table 4). The model predicts that the value of the habitat decreases dramatically after the average number of miles of road/sq. mile of habitat increases over two. The Blue Creek project area currently averages 4.8 miles of road per square mile of habitat. The current number of H.U.'s in the Blue Creek project area is 608. With road management the number of H.U.'s would increase to an estimated 3079 for a net gain of 2471 H.U.'s. (Table 5). Road management that would decrease the amount of usable roads per square mile would increase the HSl's and number of habitat units over five hundred percent.

Table 4 . White-tailed Deer HSI by site number and habitat tYPe.

\begin{tabular}{lcc}
\hline Site $\#$ & Habitat type & HSI \\
\hline 1 & (PP3) & .2 \\
2 & (PP1) & 0.1 \\
3 & (PP3) & .136 \\
4 & (PP1) & .0064 \\
$6 A$ & (PP2) & .152 \\
$6 B$ & (N+O) & .16 \\
7 & (MC3) & .128 \\
10 & (MC3) & .16 \\
11 & (PF3) & .144 \\
12 & (PF2) & .05 \\
13 & (PF2) & 0.16 \\
14 & (PP2) & .0126 \\
15 & (PF2) & .072
\end{tabular}


Table 5. White-tailed deer mean HSI and habitat units by habitat type including estimated habitat units with management.

\begin{tabular}{cccccc}
\hline Habitat Type & $\begin{array}{c}\text { Current } \\
\text { HSI }\end{array}$ & Acres & $\begin{array}{c}\text { Current } \\
\text { H.U. }\end{array}$ & Est. HSI & Est. H.U. \\
\hline (N+O) & .16 & 592 & 95.0 & .80 & 474 \\
(PP1) & .01 & 1009 & 10.0 & .04 & 40 \\
(PP2) & .10 & 1815 & 181.5 & .50 & 908 \\
(PP3) & .17 & 1220 & 207.5 & .84 & 1025 \\
(PF2) & .11 & 89 & 10.0 & .58 & 52 \\
(PF3) & .14 & 683 & 96.0 & .78 & 533 \\
(MC3) & .16 & 9 & 2.0 & 1 & 9 \\
(R) & .16 & 38 & 6.0 & 1 & 38 \\
\hline Totals & & 5455 & 608.0 & & 3079
\end{tabular}

\subsection{Sharp-tailed Grouse}

Currently there are 1153 H.U.'s available out of 1593 possible for sharp-tailed grouse. (Table 6). However, there are no sharp-tailed grouse on the reservation at this time. The HSl's for the project area are sufficiently high enough to warrant a possible reintroduction effort. Management efforts would focus on increasing the size and amount of shrub cover, while reducing conifer tree cover. This would increase the H.U.'s available for sharp-tailed grouse to 1307 for a net gain of 151 H.U.'s Since the birds are not currently inhabiting the area all H.U.'s would be considered as net gain H.U.'s following successful establishment of grouse

Table 6. Sharp-tailed Grouse HSI and habitat units by habitat type, including estimated habitat units with management.

\begin{tabular}{cccccc}
\hline Habitat Type & $\begin{array}{c}\text { Current } \\
\text { HSI }\end{array}$ & Acres & $\begin{array}{c}\text { Current } \\
\text { H.U. }\end{array}$ & Est. HSI Est. H.U. \\
\hline (PP51) & .8 & 989 & 799.2 & .85 & 849 \\
(N+O) & .6 & 589 & 353.4 & .77 & 454 \\
\hline Totals & & 1588 & 1152.6 & & 1303
\end{tabular}




\subsection{Beaver}

According to the model the habitat that is usable for beaver is in good condition (Table 7). The HSI value for site 12 is lower due to water level fluctuations. It seems that the best way to gain H.U.'s for beaver is to increase the amount of riparian habitat in the Blue Creek project area.

Table 7. Beaver HSI by site number and habitat type.

\begin{tabular}{lcccc} 
Site \# & Habitat Type & HSI & Acres & H.U. \\
\hline 7 & (R) & 1 & 27 & 27 \\
8 & (PP52) & 1 & 191 & 191 \\
9 & (PF53) & 1 & 173 & 173 \\
12 & (PF52) & .5 & 17 & 8 \\
\hline Totals & & & 408 & 399
\end{tabular}

In summary, Table 8 below presents estimated current and projected Habitat Units with management for Blue Creek.

Table 8. Total current H.U.'s and estimated H.U.'s with management for all indicator species.

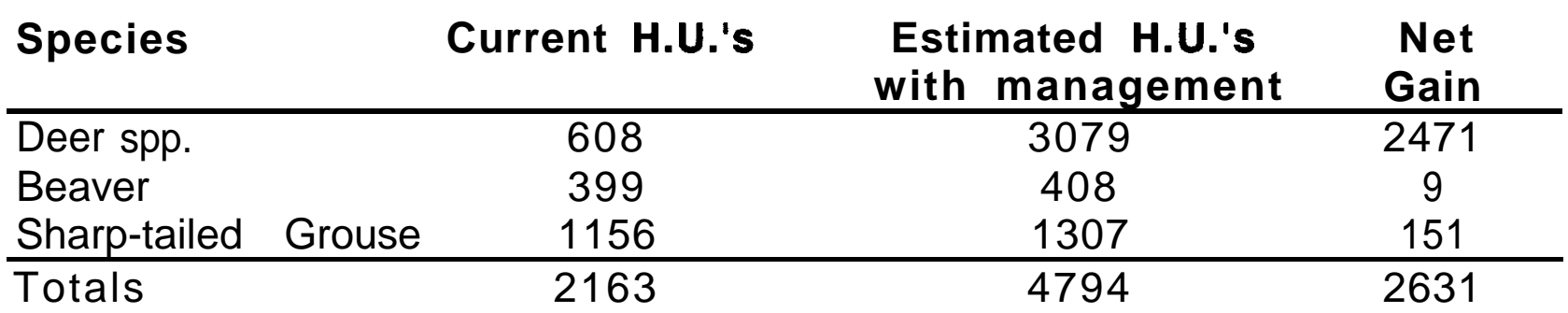




\subsection{DISCUSSION}

\subsection{Species Habitat Management}

The three indicator species were chosen to gauge the current condition of the existing habitat, as well as to set goals for future improvement. The condition of the existing habitat was measured through the HEP process discussed earlier. In this section, discussion of each species and respective habitat management tasks is by habitat type. The HEP variables are used as a basis of management. However, also included are additional management techniques not included in the model that are important to the species, as well as to increase both habitat and wildlife diversity on project.

\subsection{Deer}

The primary target species of the project are deer, both mule and white-tailed. Reasons for this are the tribes strong interest in their hunting culture, and the economic and dietary importance of deer. All habitats in the project are considered useful to deer (Table 9; Figure 3).

Management prescriptions will be given for all habitat types under winter range guidelines. These guidelines are primarily designed for mule deer. This was done for two reasons: 1) eastern Washington mule deer populations are stable or even declining, and 2) white-tailed deer are more adaptable to habitat types and changes then mule deer. Both species will benefit on project, but where possible we will manage habitat for mule deer needs. Winter range management was selected in this project area for several reasons. Helicopter surveys in winters of 1988 and 1989 showed this area to have a higher density of both species than any other area on reservation. Taking advantage of the primary south and west slope aspects we can improve the habitat types for wintering deer. We can enhance both on and off-reservation resident and transitory deer with this project. Finally, the importance of deer to the tribe has already been discussed.

Good quality winter range assists deer in maintaining their energy and health by slowing their rate of weight loss in winter. This improves chances for their own survival, as well as that of their developing fawns. Deer try to maintain energy and weight by using areas with shallow snow, adequate food and sufficient shelter. Snow depth affects ease of movement. Deep snow causes deer to use more energy as they attempt to move through it. Deeper snow also buries much food, especially in 
clearcuts and other openings. Sufficient shelter is represented by both topographic factors and vegetation. The former can strongly influence the latter (Figure 4). Snow depths are shallower on slopes than flat areas. Aspect influences snow depth, daytime temperatures and vegetation type and density.

Vegetation influences deer condition by the degree it provides shelter and food. Vegetation provides shelter by intercepting snow, moderating temperatures and offering security from harassment. At either end of the vegetation structure spectrum are clearcuts and old growth. Clear cuts provide nutritious forage but little shelter. In addition snow often buries the food. Old forests provide excellent shelter but little ground forage. However forage is provided by lichen and branch litter-fall. An older age Douglas Fir stand is a preferred winter range type in snowpack zones (Figure 5). It provides the best shelter and supports desired lichens. The preferred lichen Alectoria americana is present. As lichens grow slowly, older tree age classes are needed to support them. A current problem with fir on the project is its propensity to suffer some mortality due to root rot. From a commercial standpoint this is certainly undesirable. However, under wildlife goals this may not be such a problem. Occasional mortality results in natural openings, snag creation and downed material on the forest floor. This may more closely resemble some conditions of the old growth forest. The Blue Creek site has a generous mix of slope, aspect and vegetation types suitable for winter range enhancement. The following section discusses the specific vegetation types and their management. The BIA - Spokane Agency Forestry Branch has classified the reservation by vegetation cover type (Table 9). Cover types can be classified into 2 broad associations: commercial forest and non-commercial forest. Non-commercial forest is non-economic forest types such as hardwood stands, as well as riparian zones, rock outcrops, agriculture and water. Commercial forest types are primarily Ponderosa Pine and Douglas Fir dominated. Within these cover types the forest types only have been further classified according to both size class of the dominant size trees and stocking density. Uneven age is an exception to a single dominant size class, that is, there are at lease 3 canopy layers, or tree sizes. Uneven age is prevalent on the project area. Stocking density is a function of canopy cover, with four classes from 0 $100 \%$.

Deer management prescriptions will be discussed by each cover type within the two associations. 
INFLUENCE OF ASPECT

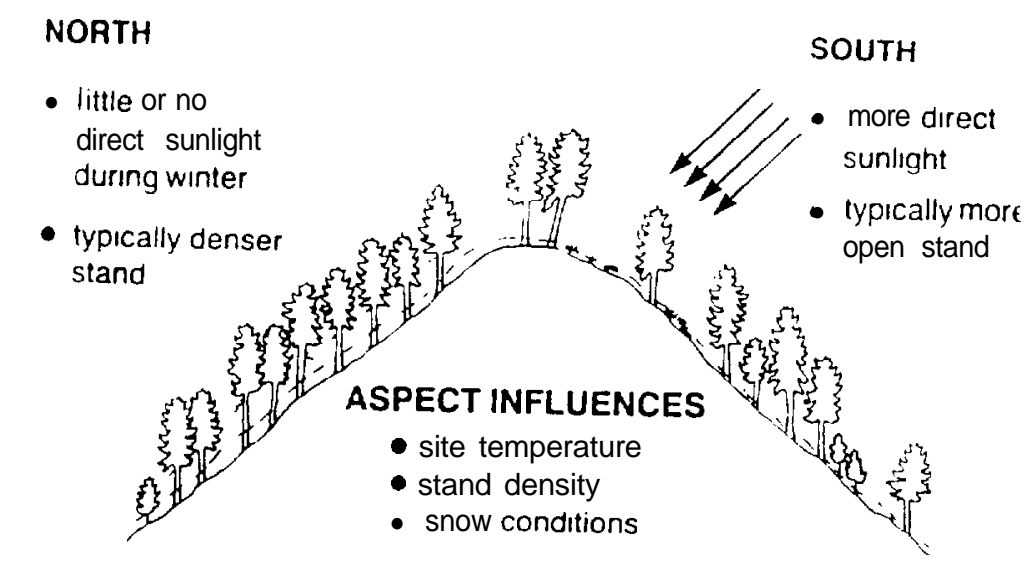

INFLUENCE OF SLOPE ON SNOW DEPTH

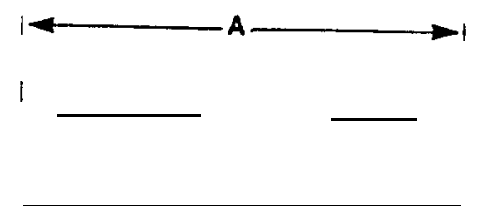

Deeper Snow Depth

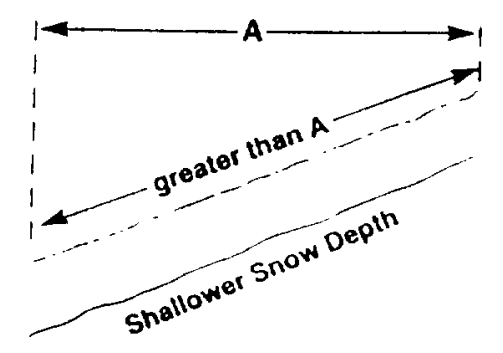

Figure 4. Influences of slope and aspect

\section{QUALITY OF DOUGLAS-FIR FORAGE \\ IS NOT UNIFORM}

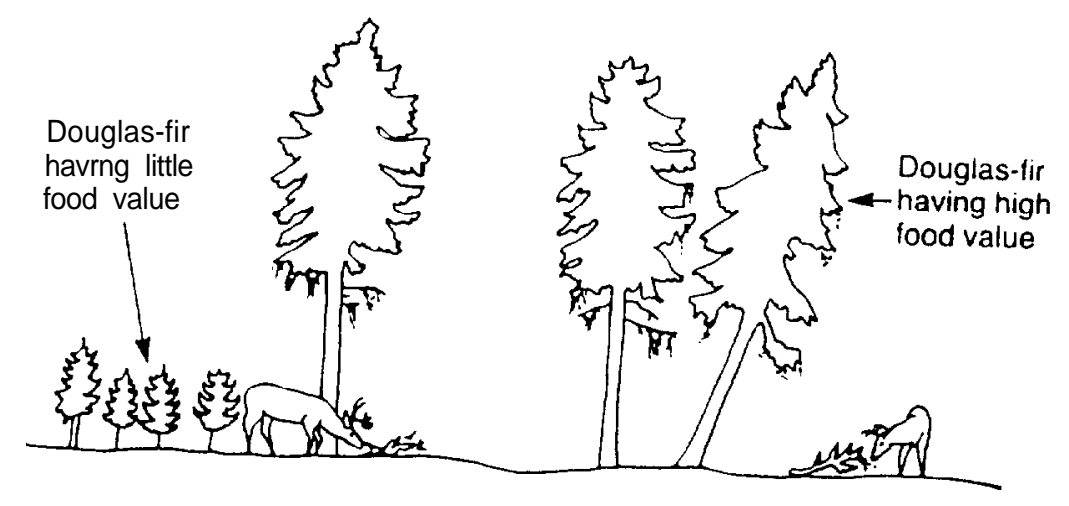

Figure 5. Douglas fir value to wintering deer 
Table 9. Cover types, frequency of types, and acreage used in deer management, Blue Creek Project.

\begin{tabular}{lcc}
$\begin{array}{l}\text { Frequency } \\
\text { of Type }\end{array}$ & Cover Type & Acres \\
\hline 1 & $\mathrm{H}$ & 3 \\
1 & MC531 & 9 \\
7 & $\mathrm{~N}$ & 415 \\
12 & 0 & 177 \\
1 & PF32/PF23 & 5 \\
1 & PF33/PF23 & 7 \\
1 & PF43/PF33 & 32 \\
1 & PF43/PF34 & 13 \\
2 & PF51 & 34 \\
4 & PF52 & 50 \\
12 & PF53 & 453 \\
5 & PF54 & 178 \\
1 & PP23 & 4 \\
1 & PP24 & 11 \\
1 & PP41/PP33 & 8 \\
9 & PP51 & 1001 \\
24 & PP52 & 1815 \\
16 & PP53 & 1172 \\
2 & PP54 & 33 \\
6 & R & 35 \\
2 & S & 10 \\
\hline
\end{tabular}

${ }^{1}$ First number in sequence is size class, second is density class.

$\begin{array}{llll}\text { Sizes: } & 1 & = & \text { seedling sapling } \\ & 2 & = & \text { poletimber } \\ & 3 & = & \text { small sawtimber }\left(9-16^{\prime \prime} \mathrm{dbh}\right) \\ & 4 & = & \text { large sawtimber }\left(>16^{\prime \prime} \mathrm{dbh}\right) \\ & 5 & = & \text { uneven aged } \\ \text { Density: } & 1 & = & \text { scattered stocking } \\ & 2 & = & \text { light stocking } \\ & 3 & = & \text { medium stocking } \\ & 4 & = & \text { full stocking }\end{array}$




\subsubsection{Commercial Forest Types}

Because no intensive site-specific deer research is available for our project area, prescriptions are based on 2 primary sources. Thomas (1979) has summarized an extensive body of knowledge for the Blue Mountains south of our project. Many habitats here are similar to Blue Creek. Recently new management prescriptions have been suggested for Douglas fir habitat in British Columbia (Armleder et al 1986). Douglas fir management will add to habitat diversity at Blue Creek project.

\subsubsection{Ponderosa Pine (PP)}

Ponderosa pine is the most common tree and dominant cover type on the project. Pine dominated types make up 4044 acres (Table 9). Most of this type is found at lower elevations and on flat or south aspect slopes as it is more drought tolerant. Due to drier conditions, stocking densities are generally lower, meaning cover is often less than desired for deer requirements. Except for two small groups (4 and 11 acres) of poletimber (cover types PP 23 and 24), and an 8 acre mix (PP 41 and PP 33) all other ponderosas pine dominated forest is uneven-aged. Uneven aged types will primarily be managed for density limitations, while maximizing all age class components.

The scattered density $(0-10 \%$ cover) ponderosa pine class (PP 51 in Table 9) comprises 1001 acres or $18.3 \%$. Due to this very low cover, in reality it is not managed as commercial forest. Ecologically it more closely resembles shrub steppe due to high shrub density, especially antelope bitterbrush. Bitterbrush is a preferred deer browse. It will be encouraged where it is found lacking, for example in burned areas. Goal of bitterbrush management is to have approximately equal percentages in each of 3 age classes: seedling, young and mature. Density from 20003000 stems per acre (20\% canopy coverage) with a mean height of less than 3 feet is desired (Roberts et al. 1989). Burning of old, decadent stands in 20-40 acre blocks will give a patchwork of age classes. BIA Fire Management will be utilized to plan and manage use of prescribed fire. Cattle grazing in this type will be restricted due to negative impacts to preferred bluebrunch wheatgrass-Idaho fescue bunchgrasses, and preference of mule deer for these types (Bodurtha et al. 1989; Griffith and Peak 1989). Following burning these grasses will be seeded at 8-10 pounds per acre. Little can be done here to improve the limiting factor of thermal cover (Figure 6A). Site conditions are too harsh for high-success tree establishment ( $T$. Hensold, pers. comm.). Bitterbrush and road management (See Section 52.5) will be primary emphasis here for deer. 


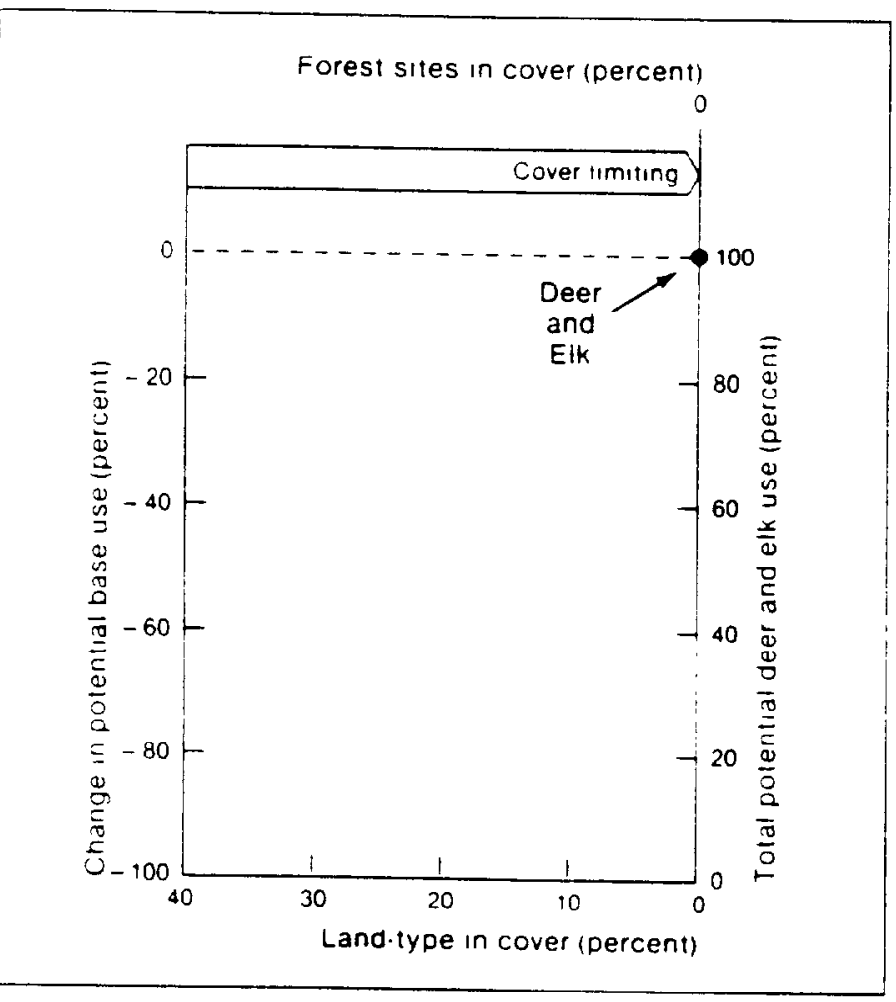

Fig. 6A

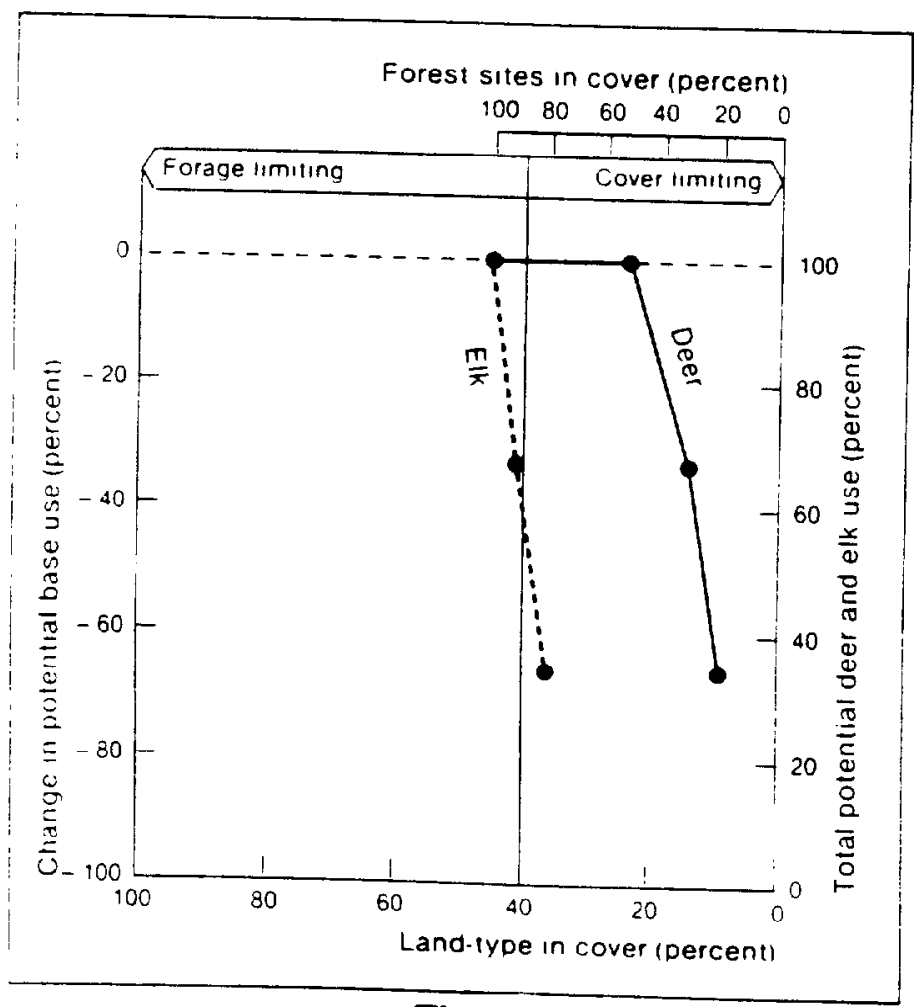

Fig. 6C

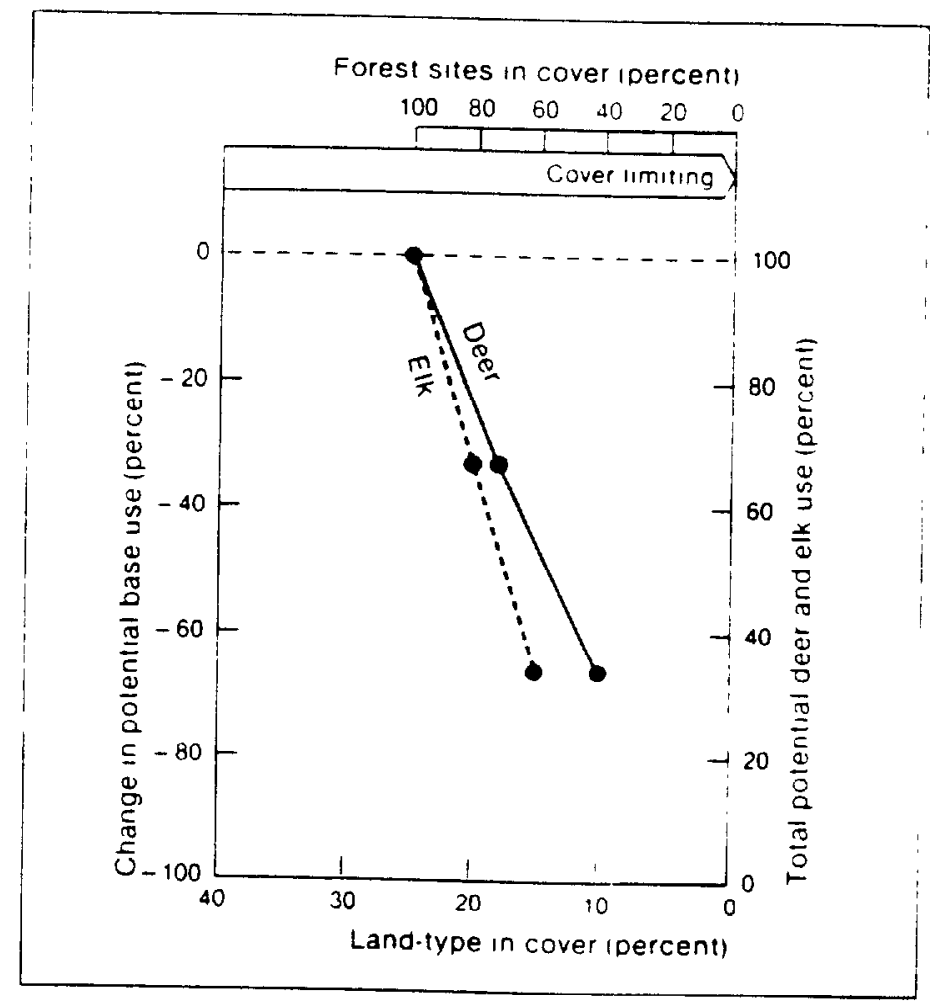

Fig. 68

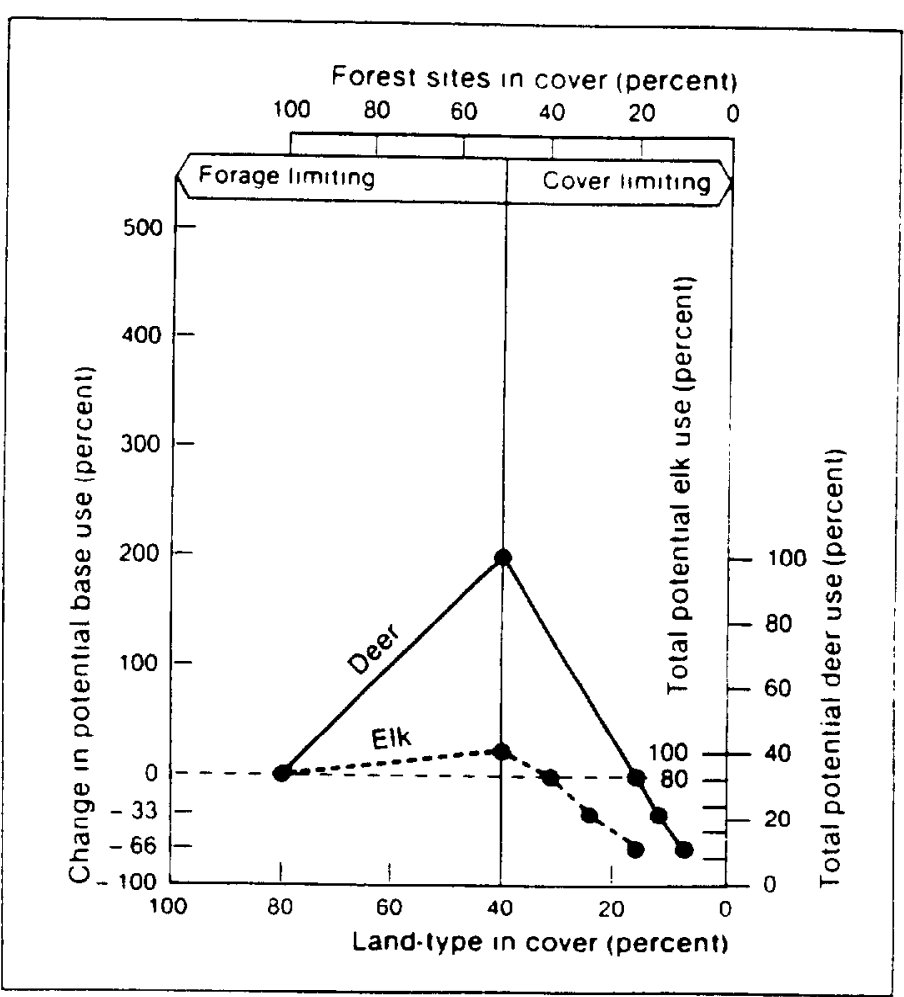

Fig. 6D

Figure 6. Deer and elk response to alteration in cover-forage area ratios (from Thomas et. al 1979). 
Uneven-aged light density (1 $1-40 \%$ cover) ponderosa pine (PP 52) makes up 1815 acres or $33 \%$ of the unit. Cover is also the most limiting factor here, until the $40 \%$ level is reached (See Figure 6B). As much of this area has the potential to naturally approach the optimum of $40 \%$ cover, we anticipate little active forest enhancement here. Goal will be to allow the area to mature undisturbed. Benefits will also accrue through road management.

Uneven-aged medium density (40-70\% cover) ponderosa pine (PP 53) makes up 1172 acres or $21.4 \%$ of the unit. Above $40 \%$ cover some timber harvest can occur without detriment (Figure 6C). However the figure does not show a benefit to harvest, only that it can occur at moderate levels. Currently most older age class trees are periodically removed through selective cutting. Under our proposed management this class would be allowed to mature and be retained. In addition a combination of group selection, road management and replanting with Douglas fir will be implemented.

Finally, full density $(71-100 \%$ cover) pine (PP 54) is present but at a low level (33 acres; 0.6\%). Figure 6D illustrates an improvement in deer benefits can be expected with a reduction in cover towards $40 \%$. Largest trees will be retained, group selection will be implemented, and Douglas fir will be underplanted at rate of 200 stems/acre.

\subsubsection{Pine-Fir Codominant (PF)}

GIS identified 27 polygons where ponderosa pine and Douglas fir were co-dominant tree species within the canopy. Most of these polygons are found on north aspect slopes or within more mesic environments of Blue, Sand and Oyachen Creeks. The great majority (631 of 772 acres or $82 \%$ of this type) is in larger size/age classes and higher stocking densities (PF 53 and 54). This is preferred, as an optimum winter range condition goal of all PF types is to favor larger size classes of Douglas fir. Pine will therefore be reduced to subdominant levels, by removing size classes 1-3. Large size class 4 will be retained for its structural value to deer as overhead cover, and to many other mature/old growthdependent wildlife species. In addition its value as a seed source will help maintain stand diversity, in the event of root rot or spruce Budworm mortality to Douglas fir.

Douglas fir is more effective than pine in intercepting snow, making it easier for deer to move and find food under the canopy. A multilayed 
stand improves body heat retention. Interlocking canopy is a goal here. Ponderosa pine and other trees will only be reduced to favor growth of fir. It is desirable to have somewhat less then $100 \%$ canopy cover for ground forage production and vertical structure diversity. Objective is to hold cover between $70-90 \%$, primarily of Douglas fir.

Spacing of regeneration is important. Deer do not extensively use dense stands of regeneration. Thinning produces faster growing trees with wider crowns. Thinning will not be so heavy that slash accumulation exceeds one foot. Slash can inhibit movement of deer.

\subsubsection{Non-Commerical Cover Types}

There are 640 acres of non-commercial forest cover types within the project.

Non-commerical forest land $(\mathrm{N})$ makes up $65 \%$ of the total in this category. It is primarily vegetated with bitterbrush, bunch grasses and forbs. Current cattle stocking is low so that this range is in good condition. However this could change with cattle prices or range demand. For example, in the early-mid 1980's cattle (and horse) densities were much higher and so range condition was poorer ( $\mathrm{M}$. Brittingham pers. comm.) Restricting cattle use to current levels, or below, is desired. However, this can represent lost economic opportunities for tribal members and so needs to be considered in costs and the mitigation lease. Bitterbrush will be managed as in Section 5.2.1.1.

Open land (0) is mostly steep rock outcrops in the Riverbreaks zone. This type of area can be important as refugia to mule deer when being harassed. It will remain undisturbed, i.e. access will not be developed. Due to its dry, rocky nature there is probably little vegetation management that can be done, except to protect it from livestock. Hardwood $(H)$, Riparian $(R)$ and Surface water (S) only make up 48 acres or less than $1 \%$ of the project area. However they can be more important than their area indicates. They are somewhat similar in vegetation type and so are pooled here for deer management. Vegetation in these more mesic sites is often dominated by deciduous trees and shrubs. This is an area of hot, dry summers and conifer-dominated habitats. Therefore deciduous trees and shrubs are disproportionally important. In the West, deer use in aspen forests for example is very important throughout the year due to nutritious forage (DeByle 1985). Deciduous growth on Blue Creek seems to occur in two situations: springs and hillside gulleys, and within Blue and Oyachen Creeks. Color infared aerial photographs were 
used to identify deciduous growth. Aerial overflights permitted stratification into tree or shrub species. Trees on hillsides were found to be aspen. Shrubs in gulleys were most commonly mountain maple, willow and cherry. Several sites were identified for development of springs as water sources (Table 10 and Figure 7). Development of these hillside springs will better distribute deer and grouse use away from the Blue Creek riparian corridor. Increased water will also allow expansion of deciduous species, including planting. We will plant aspen in clumps of 610 ten foot tall trees, and fence with 6' tall field fence. Purpose is to permanently protect the "parent clump" from deer overbrowsing. Root sprouting should rapidly follow allowing clump expansion. Conifer invasion will be controlled to prevent overtopping and water competition. Figure 11 illustrates sites for management of these cover types and developments.

Table 10. Springs, ponds and tanks known for Blue Creek Project area.

\begin{tabular}{|c|c|c|c|}
\hline SPT \# & Attribute & Use Noted & Comments \\
\hline 100 & Pond & 0 & Seasonally dry; aspen site \\
\hline 101 & Pond & 0 & Seasonally dry; aspen site \\
\hline 102 & Spring & Wildlife & Aspen site; tank potential; \\
\hline 105 & Tank & Livestock \& Wildlife & $\begin{array}{l}\text { Running water present; } \\
\text { ruffed grouse brood }\end{array}$ \\
\hline 106 & Spring & Wildlife & $\begin{array}{c}\text { Standing water-tank } \\
\text { potential }\end{array}$ \\
\hline 107 & Spring & 0 & Moist ground-tank potential \\
\hline 108 & Spring & Wildlife & Moist ground-tank potential \\
\hline 109 & Spring & 0 & Moist ground-tank potential \\
\hline 237 & Spring & Wildlife & Running water present \\
\hline 240 & Spring & Wildlife & $\begin{array}{l}\text { No running water; tank } \\
\text { potential; ruffed grouse } \\
\text { nest in aspen }\end{array}$ \\
\hline
\end{tabular}

\subsubsection{Timing of Treatment}

Timber treatment will only be conducted from September December. Purpose is two fold: harvesting at this time may provide a short-term supply of forage over winter, and slash will dry prior to bark beetle dispersion in spring and summer. To minimize Douglas fir bark 


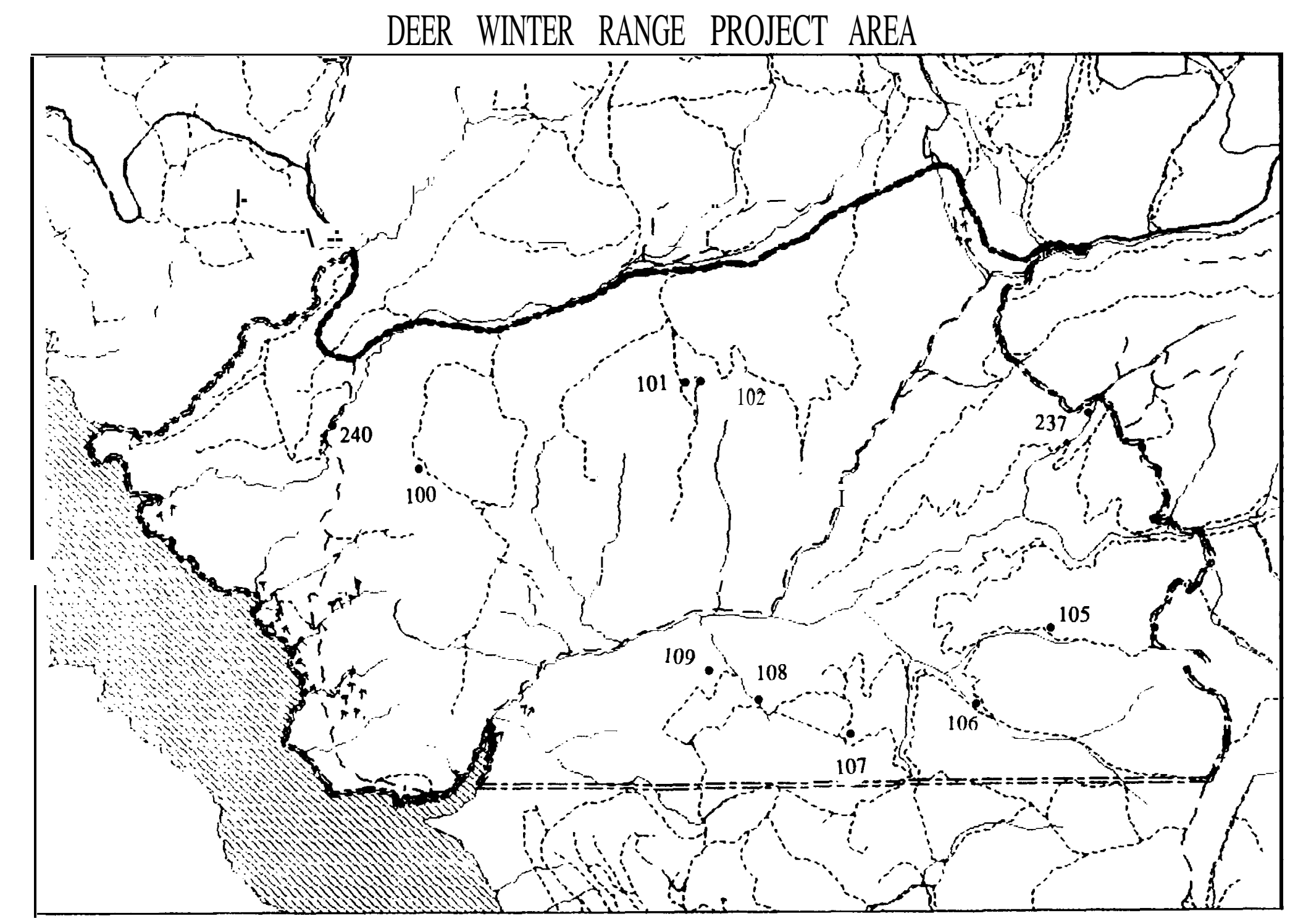

Figure 7. Existing and proposed hardwood and spring sites

$\#$ = spring/hardwood site

if = hardwood site 
beetle mortality the following guidelines from Armleder et al (1986) will be followed:

Principles for Stand Protection

Douglas-fir bark beetle is a source of mortality in mature and overmature firs stands. Each year a new brood of beetles fly and attack trees from mid-April to June, with a second smaller flight occuring in July and August. Trees weakened or damaged (including freshly felled trees) are most susceptible to attack, and poor logging practices can encourage the spread of the beetle. Because maintenance of mature and over-mature trees is of prime importance on winter range, extra care must be taken to minimize mortality from the beetle. Ways of minimizing a beetle problem are explained below.

1. Slash must not be piled against trees. Douglas-fir beetles are attracted to slash, and will also attack standing trees next to it.

2. All slash over 20 centimeters in diameter should be removed because it attracts beetles.

3. Damage to residual trees should be minimized because beetles are attracted to damaged trees.

4. Severely scarred trees (i.e., over half of the circumference of the bole) should be removed.

5. Remove beetle attacked trees.

6. Slash piles should be burned before they become breeding grounds for more beetles.

7. Logging operations should be scheduled as long before the beetle flight as possible to allow the logging debris to dry. Late summer and fall are ideal.

\subsubsection{Road Management}

(This section was written by J.B. Bright and Christopher Merker, student and research associate respectively, at Eastern Washington University.) 
Recent research has clearly shown the adverse impact of vehicle traffic to habitat use by deer and elk species (Thomas et al. 1979; Witmer and deCaleste 1985). The presence of roads open to traffic, and the density of those roads has a direct bearing on deer and elk (and presumable other wild ungulates) use of the adjacent habitat.

Because of this, road density was an important weighted component of the deer HEP model. Road management is expected to give the greatest rate of return on improvement practices for deer. The objective is not to prevent human access to the area, but to encourage more compatible types of access. For example, hunting access by foot, mountain bike or horseback is acceptable. However these uses cannot be expected to occur if they are in direct competition with unrestricted motor vehicle use. The reserving of a portion of the project area for non-motorized use will create the only area of its type on reservation.

All reference material relating to road management for big game showed that disturbances caused by people are the most important factors regulating actual use of habitat by big game. These disturbances originate from roads, both from construction and their subsequent use. The area of avoidance by big game has been reported to be one-fourth to one-half mile from the road, depending on the amount of traffic, road quality, and density of cover near the road (Lyon 1979). However, the effects of roads on big game use of habitat may be mitigated by a system of road closures (Witmer and deCalesta 1985). Road closures restricting motor vehicles can also improve the quality of the recreational experience (Beckstead 1985), thus creating multiple benefits for both the animals and people that share the habitat.

Forest roads are not inherently bad, since permanently closed and seeded roads are often preferred by big game as travel ways (Leege 1984). In addition, roads allow managers to efficiently move commercial products such as timber, firewood, and minerals, as well as allow easier control of fire and the spread of tree diseases (Beckstead 1985). Therefore, it is apparent that in some situations the controlled recreational and commercial use of roads can be a major impact on the success or decline of big game herds, and thus has become a fundamental tool in wildlife and habitat management.

Factors that a road management plan should take into consideration are road density, road type, cover type, terrain characteristics, and the big game management objectives. There are three classifications of roads that play an important role in evaluating an area. Main or primary roads 
are one and one half lanes wide or more, receive constant maintenance, are the most heavily used, and have the greatest impact on big game distribution. Secondary roads are somewhat improved with irregular maintenance and moderate use. Primitive roads are one lane unimproved, seldom maintained, with little motorized traffic, and have the least impact on big game distribution (Perry and Overly 1977).

As the density of open roads increases, the potential for harassment of big game by human use of the roads increases (Witmer and deCalesta 1985). Perry and Overly (1977), developed an open road density curve illustrating that six miles of open road per square mile allowed only 0-50 percent potential use of the habitat by deer (Fig. 8). Whereas, one mile of open road per square mile permitted about 95 percent potential use of the habitat. Similarly, in regards to cover availability, Lyon (1979), found that the area avoided by big game increased where the density of the tree cover was low. Thus, forest roads open to traffic caused available habitat to be less than fully effective.

There are several methods for closing roads which may be used, such as: tank traps (which are ditches combined with large mounds of dirt), immovable boulders, bridge removals, signs and lockable gates. Each method has shown varying degrees of success in achieving the maximum benefits. Leege (1984), determined that gates were $70 \%$ effective in reducing motorized disturbance if they allowed for a minimal level of administrative activity and some trespass. He also felt that roads closed completely with permanent barriers reduced disturbance by $90 \%$. How ever the three primary drawbacks of gates used to close roads are: vandalism, material cost of gates, and the negative "keep out" message associated with gates (Shirato and Watson 1990). Strategically placed signs and pamphlets informing the public of the reasons for and benefits. of road closures will be used to reduce the drawbacks of gates and enhance their effectiveness. Decisions for implementing each type of road closure will depend on the most appropriate and effective technique under each circumstance.

The goals of a road management plan on the project are the following:

Reduce disturbance of wildlife during critical periods

Reduce siltation of streams

Reduce poaching of fish and wildlife

Increase habitat effectiveness and big game escapement 


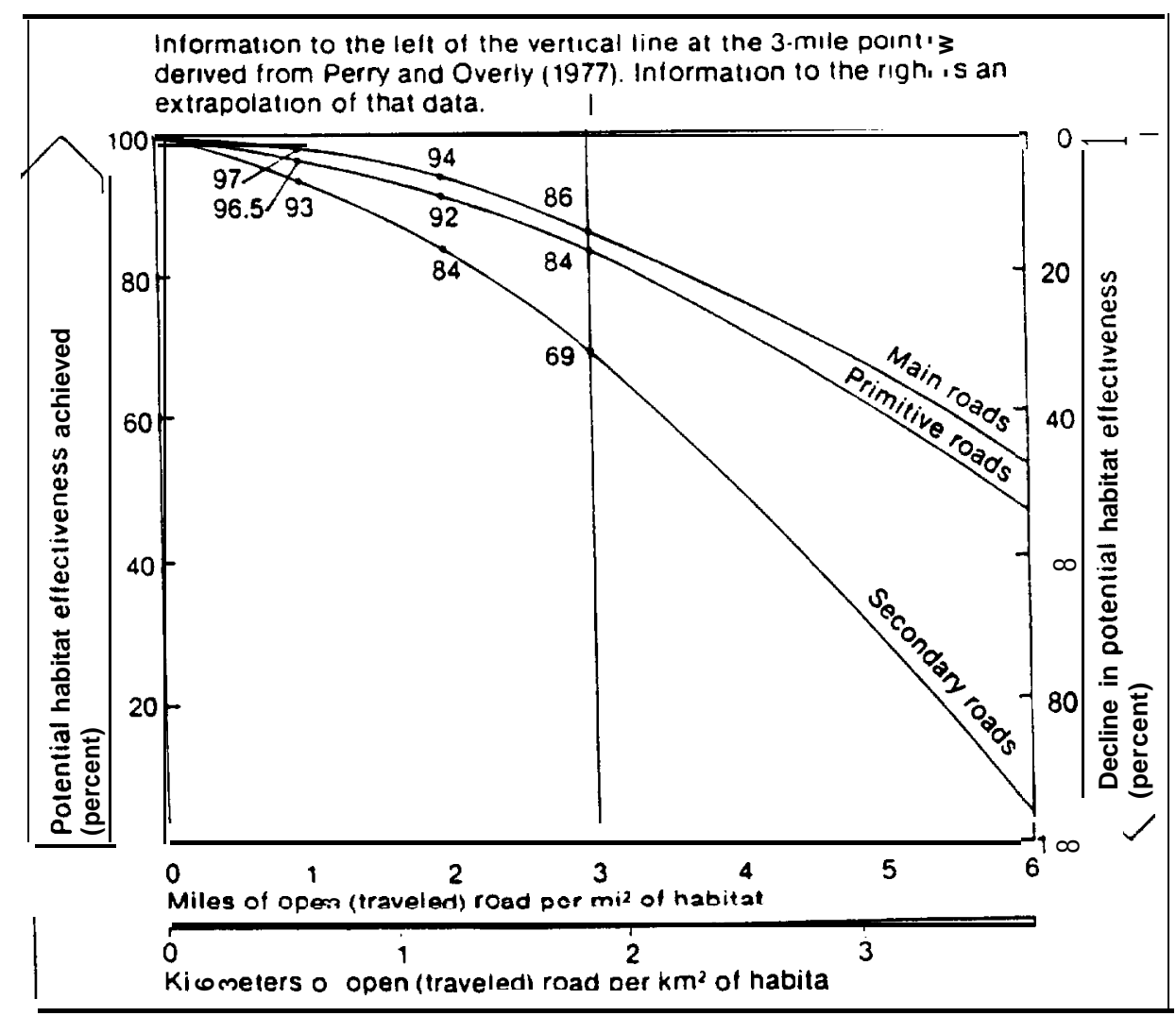

Figure 8. Impact of roads on deer use 
Provide quality fish and wildlife recreation by reducing crowding of sportsmen and other user groups

Reduce road maintenance

A Spokane Indian Reservation map was used to evaluate terrain characteristics, road type, and road density. These maps are the most recent derivatives of the 7.5 minute U.S.G.S. topographic maps, at a scale of $1: 24,000$. The determination of road type was made using the map key, which indicated a main road with a solid line and an unimproved primitive road with an intermittent line. Site visits of the area were also necessary to determine the most probable method of permanent road closure for each point of access.

Key roads were identified that would allow the best access to each area for the purpose of fire control. These key roads will be gated, while all other interconnecting roads will be barricaded using tank traps in strategic locations near access points off the open main roads.

The proper implementation of this plan requires the construction of 9 tank traps and 7 gates at specific access points (Fig. 9). Informational signs regarding the area closures will be installed at each access point with a gate.

Blue Creek loop road from the paved primary road to Lake Roosevelt and back to the paved road is considered a secondary road. It also parallels the creek. The combination of a heavily travelled secondary road, along the projects major riparian zone, makes it a top priority for closure. Gates will be used to allow maintenance. Both gates on the Blue Creek loop road will remain open seasonally from 1 April until Labor Day. This will allow fishing and camping access to Lake Roosevelt during spring and summer. Parking areas, with signs fully explaining road management purpose, will be installed in front of all gates. All other closures will have signs simply stating area is closed to motor vehicle traffic. Prior to permanent closure, roads will be ripped, then seeded with legumes preferred by deer and ruffed grouse.

Table 11 illustrates current and proposed road miles following closure per square mile of project by category.

Table 11. Current and proposed with management road mileage by category in Blue Creek Project. 


\section{DEER WINTER RANGE PROJECT AREA}

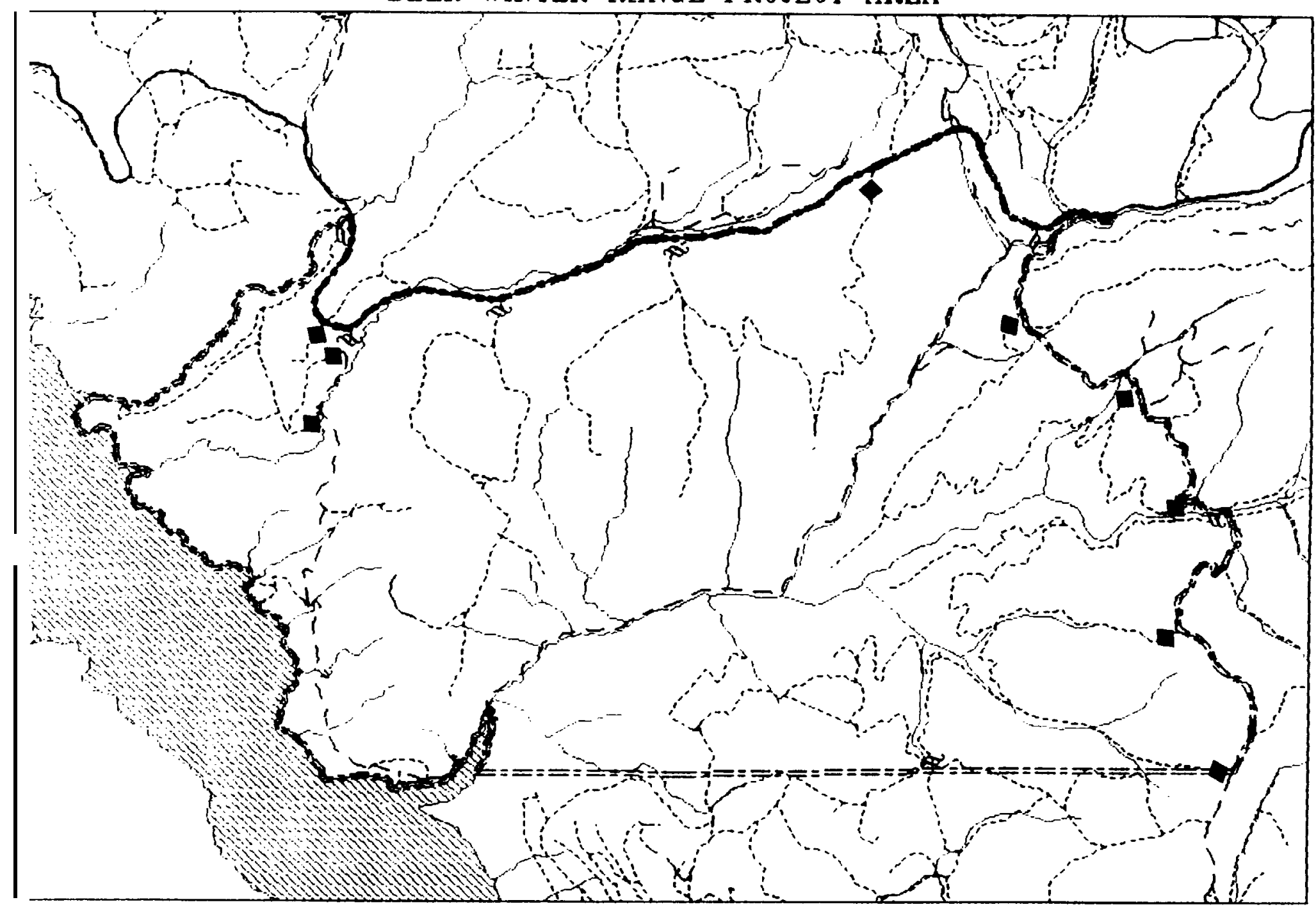

Figure 9. Road management plan 


\begin{tabular}{lcc} 
Primary & 4 & 4 \\
Secondary & 11 & $3-111$ \\
Primitive & 28 & 0 \\
\hline
\end{tabular}

1 Seasonal Closures

Lyon (1975) stated that there is no broad general rule applicable to the management of roads where elk and deer are present. Thus, each situation must be evaluated as a unique combination of terrain characteristics, cover availability, vehicular traffic and the management objectives. This fact became apparent in the evaluation of the Blue Creek area. For instance, cover ranges from densely timbered north slopes and lush creek drainages, to open grass and bitterbrush covered south slopes. Often a section of road is bordered with a good buffer strip of young ponderosa pine, but a little further down the road, adjacent cover is as sparse as foot-high grass. Consequently, standard road classification and evaluation procedures were modified. This system of closures is the most flexible means of reducing disturbances to wildlife while still allowing adequate access for fire control, vegetation management recreation, and wildlife management activities.

\subsection{Sharp-tailed Grouse}

According to the HEP results, there is currently a large area (1600 acres) of three habitat types (N,O, PP51) at a fairly high $\mathrm{HSI}$ value (mean $0.7)$ from Table 6 . Figure 10 illustrates this area. This acreage is not considered to have commercial forest value, and is mostly labelled "river break zone" in reservation zonation. Major land use is livestock grazing. Current levels of grazing do not seem to be impacting the potential habitat for sharptail. However, grazing could be expanded and could then degrade the habitat as it has done in so many other areas within the range of the grouse. The first management action will therefore be to restrict grazing to its present level. There is little published information regarding habitat use by sharp-tailed grouse in this type of habitat, i.e. riverbreaks with scattered conifer cover. They still occur in this type in Washington in Lincoln County across the river from the project (pers. obs.). Columbian sharp-tailed grouse will invade and occupy logged-over pine land in central British Columbia (D. Hancock pers. comm.). However, no published grouse and habitat correlations for this type are known. The second management action will be to selectively remove conifer trees to keep density below 10\%. Bergerud (1988) argues that tall trees are ambush points for raptors, and that predation is an important factor that can be managed in favor of grouse. However, without published data to 


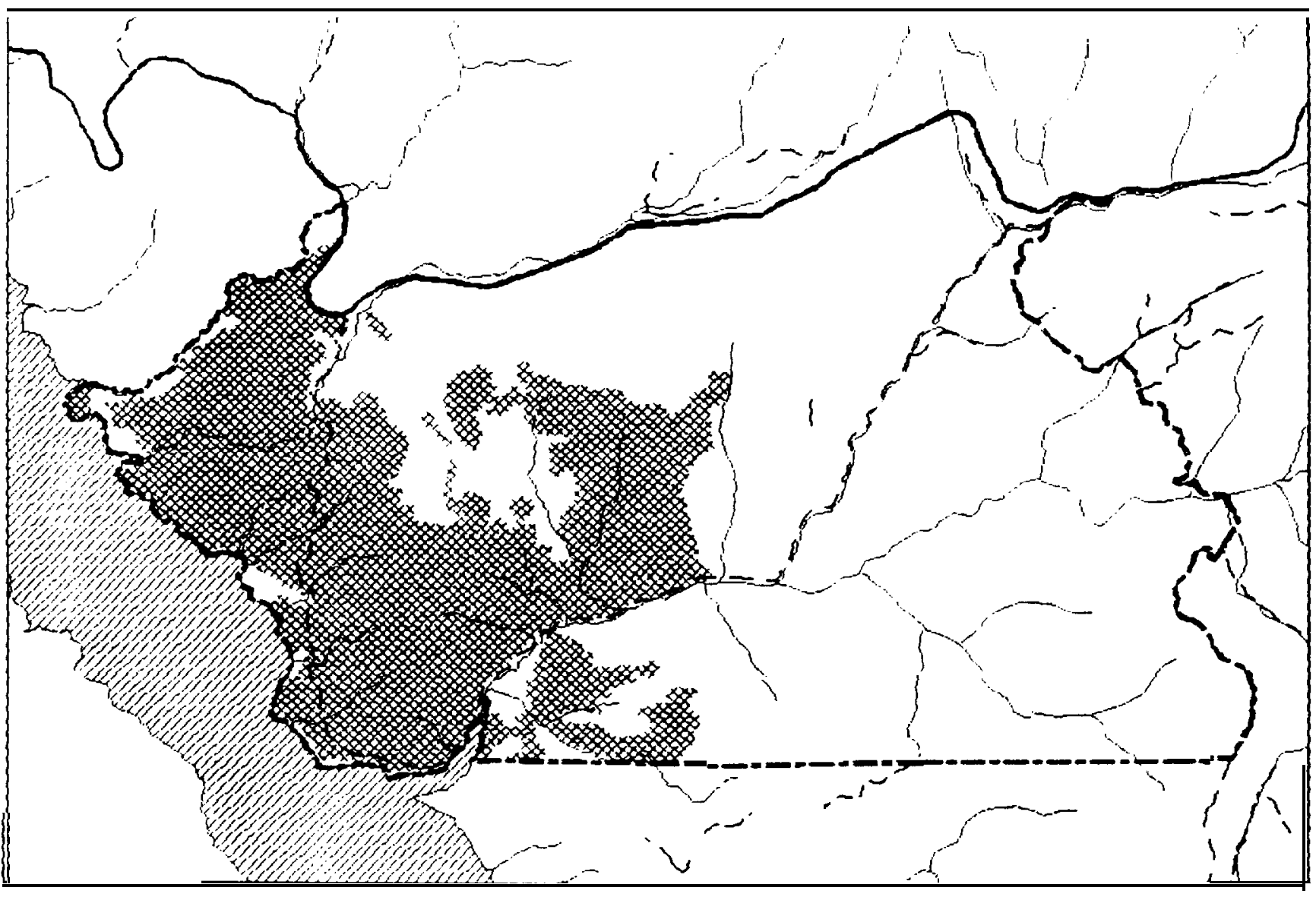

Figure 10. Sharp-tailed grouse habitat management area 
create correlative patterns, it is difficult to accurately predict changes . in HU's for sharptails.

The hardwood $(\mathrm{H})$ and riparian $(\mathrm{R})$ types amount to about 8 acres within Table 12. They can be important to birds on hot summer days due to their cooler, more moist environment. In addition, they can be of value in very severe winters as they offer deciduous budding above deep snow. . They will be managed to maintain and expand existing sites by removal of conifer competition, while establishing new sites through planting. Goal will be one hardwood stand of $1 / 4$ acre or larger per 160 acres, or 10 in the 1600 acre sharp-tailed grouse management area. There are currently 3 hardwood stands (See Figure 7).

Following habitat management, reintroduction of Columbian sharptailed grouse will follow the guidelines as suggested by Rogers (198188). Following their establishment, grouse habitat units will be credited.

Table 12. Cover types, frequency of types and acreage for sharp-tailed grouse management, Blue Creek Project.

\begin{tabular}{ccc}
\hline Cover Type & Freq. of Type & Area in Acres \\
\hline H & 1 & 3.9 \\
N & 7 & 415.7 \\
PP51 & 12 & 173.3 \\
R & 9 & 998.8 \\
\hline Total & 1 & 3.9 \\
\hline
\end{tabular}

\subsection{Beaver}

Beaver are of course heavily dependent on water for security, and adjacent uplands for food. They can travel up to 200 meters from the safety of the water to secure food in the uplands, but prefer to use an area within 100 meters. They also prefer deciduous shrub and tree species as overstory dominants. Currently the riparian corridor along Blue and Oyachen Creeks is very limited in width, and subsequently in area. There are only 27 mapped acres (Tables 7 and 13) along approximately 4 linear miles of creek. Conifers are mostly dominant in the overstory and so shade and outcompete preferred deciduous species. A generic management goal then is to remove some conifers within $100 \mathrm{~m}$ of primary use zone from the waters edge. This will be done on a selective basis. For example very steep $(>10 \%)$ gradients adjacent to the creek will not be tested. 
North aspects are cooler and moister and can be expected to support greater deciduous growth. Existing conifers $>21$ "dbh will be maintained in this zone due to their value to other wildlife species. Some habitat use by beaver can be expected from 100-200 $\mathrm{m}$ from the waters edge. However, this secondary use zone can only be expected to support 0.5 of optimum $\mathrm{HSI}$. In this area management will be more conservative to favor or enhance deciduous species where they are found. This secondary zone was not included in Table 13 and Figure 11. Figure 11 illustrates the $0-100 \mathrm{~m}$ zone as a GIS "buffer" around the permanent waters of Blue and Oyachen Creeks. The habitat within this buffer was then tabulated in Table 13.

In addition, in order to encourage more beaver use, the creation of pools is proposed on Blue and Oyachen Creek. Goal is a more permanent supply of water to mitigate seasonal variance in fluctuations. This will enhance beaver habitat as well as other wetland species such as waterfowl. Structures are planned that will also pass spawning rainbow trout from Lake Roosevelt, and provide rearing habitat for juvenile trout. To meet this goal, Eastern Washington University Geology Department created a stream morphology profile, and identified best sites and design for pool construction on Blue Creek (See Appendix 7.5). By holding more water, later into the growing season, the water table will rise and encourage riparian zone expansion. Increased riparian zone will benefit both beaver deer indicator species. This project will commence in summer 1992 as Lake Roosevelt Rainbow Trout Habitat/Passage Improvement (BPA Project \#90-1 8). It will be conducted with both fish and wildlife benefits as equal goals. For example, both deer and beaver will benefit be removing conifer competition with the deciduous riparian zone. These conifers can then be used in the construction of log weirs. Cost effective multiple benefits result. Costs to this wildlife mitigation plan are not included, as it is being funded under the above project title and number.

Pools will also be constructed within Oyachen Creek. This will be a separate effort from Blue Creek. Design will be as with Blue Creek. Costs will be included in Section 5.5 and 5.6 Workplan/Budget.

Additional habitat will be constructed on the shore of Lake Roosevelt, within the high water mark. Two five acre areas seasonally inundated by high water of the mouth of Blue creek will be planted to willow (Salix spp.). Willows withstand flooding well, and are probably the best woody vegetation for planting in the fluctuation zone of reservoirs (Haynes et al. 1988; Howells 1986). They are preferred beaver habitat, and will be credited to riparian shrub losses. 


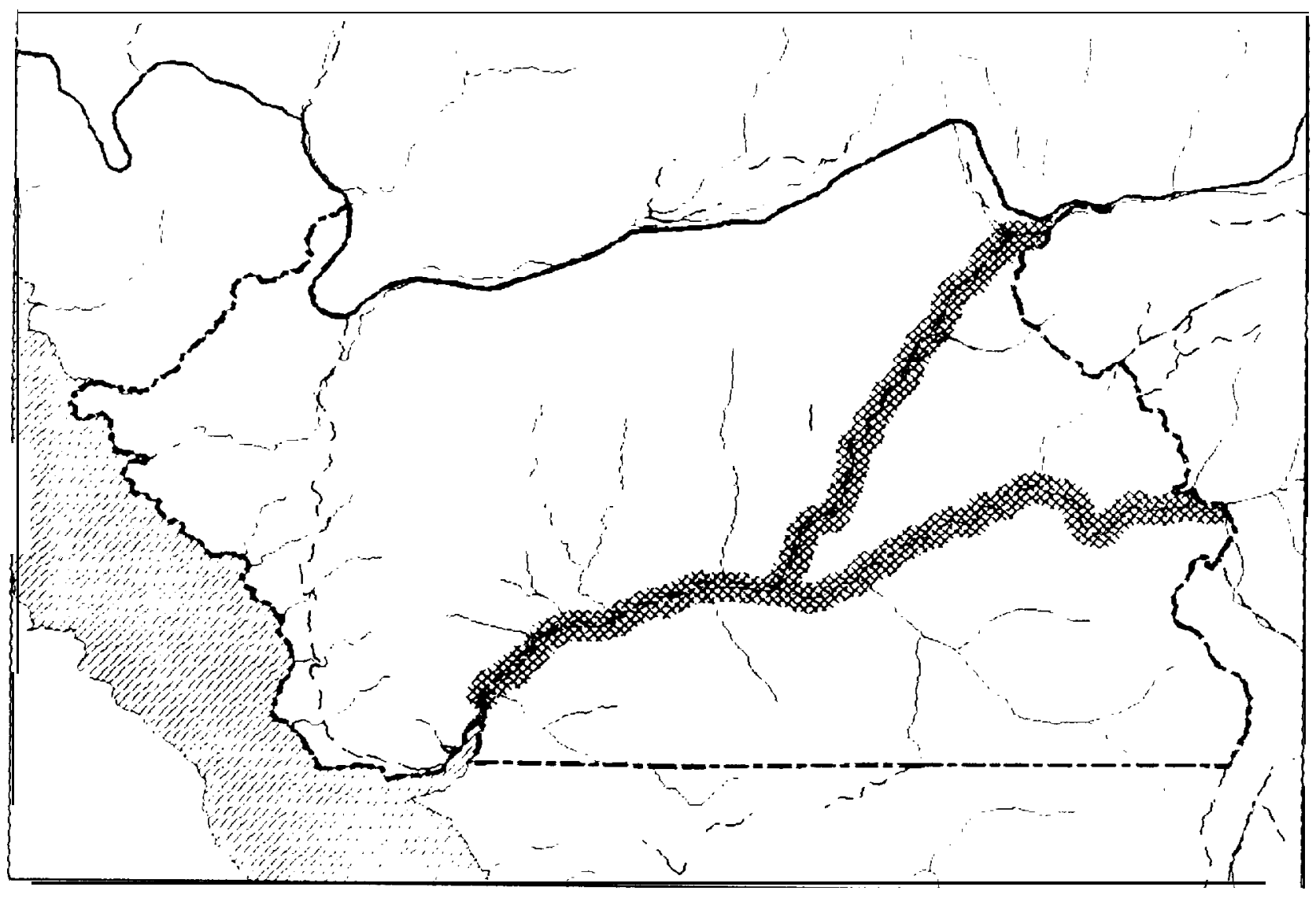

Figure 11. Beaver habitat management area 
Table 13. Cover types, frequency of type and acreage used in beaver management.*

\begin{tabular}{ccc}
\hline Cover Type & Freq. of Type & Area in Acres \\
\hline MC53 & 1 & 9.0 \\
N & 1 & 23.8 \\
PF33/PF23 & 1 & 2.8 \\
PF43/PF33 & 1 & 30.4 \\
PF43/PF34 & 1 & 7.5 \\
PF51 & 2 & 7.3 \\
PF52 & 6 & 17.2 \\
PF53 & 14 & 42.4 \\
PF54 & 4 & 73.9 \\
PP51 & 4 & 14.0 \\
PP52 & 14 & 158.9 \\
PP53 & 7 & 17.8 \\
R & 4 & 26.9 \\
S & 1 & 0.4 \\
\hline Total & 61 & 432.3 \\
\hline
\end{tabular}

${ }^{*}$ Acreage does not correspond exactly with Table 8 due to GIS breakdown of cover type detail, as well as inclusion of non-commercial forest $(\mathrm{N})$.

\subsection{Workplan (Objectives/Tasks)}

A detailed outline of each objective by task follows. The objectives can be arranged in 4 major headings:

-Conservation Lease (\#1)

@Baseline Conditions (\#2)

- Implementation (\#3-9)

*Monitoring (\#2, 10)

Objective 1. Acquire conservation leases on 5,400 acres.

Task 1.1 Appraisals on the proposed project area have been completed.

Task 1.2 Survey 5,400 acres.

Task 1.3 Draft legal language for easements/agreements between BPA and Spokane Tribe. 
Product: $\quad$ Conservation lease on 5,400 acres; Management agreements between BPA and Spokane Tribal Council; site inspected and surveyed.

Duration: One time effort.

\section{Objective 2. Baseline conditions and wildlife populations.}

Task 2.1

Aerial survey of big game annually in February.

Task 2.2

Select transects; do trail and pellet counts.

Task 2.3

Select grouse drum/hoot transects.

Task 2.4 Select riparian transect for waterfowl and furbearers.

Task 2.5 Estimate beaver populations in Blue and Oyachen Creeks.

Task 2.6 Begin photo point series at HEP sites to illustrate vegetation cover changes over time.

Product: Population estimates comparing managed and unmanaged areas over time.

Aerial Survey: 1 flight day annually in February for life of project.

Other Counts: 1 week annually in February, April, June and September for life of project.

\section{o bjective 3. Control domestic livestock.}

Task 3.1 Install one cattle guard at northwest entrance to project, one at southeast entrance, repair existing cattle guard at northeast entrance.

Task 3.2 Repair 1 mile of existing fence along north edge of Sand Creek. Build $3 \mathrm{mi}$. of new fence along south edge of Wellpinit-West End highway. Build 2 miles of new fence along east edge of project area.

Task 3.3 Move cattle and other domestic livestock off unit.

Product: $\quad$ Cattle and feral horse grazing eliminated from project area; improved range condition.

Duration: One time effort. 


\section{Objective 4. Silviculture for wildlife diversity.}

Task 4.1 Plant Douglas fir in PP53 habitat type.

Task 4.2 Harvest pine in size classes I-3 in PF habitat type to favor Douglas fir.

Task 4.3 Thin age classes I-2 in PP and PF types to increase mean true size. Treat slash.

Product: $\quad$ Presence of all forest age classes within unit; older age classes (mature, old growth) enhanced and restored.

Duration: Seasonally over life of project.

Objective 5. Enhance native grasses and restore shrub steppe.

Task 5.1 Control weed competition by applying Roundup to toad flax and knapweed in patches where it has been identified, especially along roads leading into project area (16 miles).

Task 5.2 In fall, plant native grasses and forbs.

Task 5.3 In spring, fertilize with 10N - 10K - 10P.

Task 5.4 Work with Reservation Fire Mangement and BIA Forestry to develop burn prescriptions for decadent redstem ceanothus and atelope bitterbrush.

Task 5.5 Prepare field crews for controlled burns.

Task 5.6 Burn selected areas.

Task 5.7 Collect local 1st year big sagebrush seedlings from Conservation Reserve Program plots.

Task 5.8 Grow seedlings in containers 1 year in EWU Native Plant greenhouse.

Task 5.9 Outplant in autumn/winter on west slope of mitigation site. 
Task 5.10 Collect site specific antelope bitterbrush seed.

Task 5.11 Germinate and grow in greenhouse.

Task 5.12 Outplant in winter/spring within pine habitat on project.

Product: $\quad$ Reduced weeds; enhanced native grasses; ceanothus seed scarified and prepared for germination, growth enhanced; sagebrush steppe restored to former range; bitterbrush density increased.

Duration: Annually for life of project.

\section{Objective 6. Restore and enhance hardwood and riparian habitat types to greater percent cover.}

Task 6.1 Clear existing stands of all competing conifer vegetation using Tribal forestry crews.

Task 6.2 Partially cut and/or slash burn stands to stimulate regrowth and stand expansion.

Task 6.3 Collect local root stock. In greenhouse create sucker cuttings for large scale planting stock program.

Task 6.4 In potential sites cut competing vegetation, burn slash, plant greenhouse container stock.

Task 6.5 Monitor and compare growth rates within and between treatment types.

Task 6.6 Install water collection devices at appropriate hardwood sites.

Product: Goals are to significantly increase area coverage of aspen to increase for the indicator species white-tailed deer and beaver; prepare for restoration of sharp-tailed grouse; increased water supplies.

Duration: Seasonally over 5 year term; monitoring for additional 10 years. 


\section{Objective 7. Road management.}

Task 7.1 Seed grasses and legumes on roads to be permanently closed.

Task 7.2 Close minor roads with ditching/berming.

Task 7.3 Gate main access roads into unit using reinforced metal gates.

Product: Spring/autumn transition, and winter wild ungulate range secure from undue harassment levels.

Duration: 2 months to develop; maintain for life of project

\section{Objective $8 . \quad$ Riparian pools creation.}

Task 8.1 Organize field crew and brief as to objectives and wetlands.

Task 8.2 Select pool sites.

Task 8.3 Design wiers to provide maximum pool size and stability, with unobstructed fish passage using completed geomorphological stream survey..

Task 8.4 Construct pools during dry work season.

Product: Small pools created within stream segments currently lacking this habitat. Beaver and riparian shrub habitat units as well as resident salmonid species will benefit and increase.

Duration: One time implementation in summer; 0 \& $\mathrm{M}$ and monitoring for life of project.

\section{Objective 9. Sharp-tailed grouse restoration.}

Task 9.1 Following completion of Objectives 3, 5 and 6, determine suitability of restored habitat for introduction of sharptailed grouse.

Task 9.2 Identify potential reintroduction sites. 
Task 9.3 Acquire and liberate sufficient number of grouse.

Product: $\quad$ Restoration of extirpated species suffering greatest habitat losses due to construction of Grand Coulee Dam.

Duration: 2 months in habitat assessments; 2 months each spring over minimum of 3 years to conduct grouse releases; 0 \& $\mathrm{M}$ and monitoring for life of project.

\section{Objective 10. Monitor habitat.}

Task 10.1 At HEP sites select and permanently stake 0.1 acre plots/habitat type.

Task 10.2 Collect and record data, including for example grass, shrub and tree cover, number of snags, etc.

Task 10.3 Compare project area plot data trends.

Product: $\quad$ Permanent vegetation plots for comparing managed to unmanaged sites and to compute trends in order to determine if there is improvement in habitat; i.e., if treatment is effective in increasing wildlife numbers (Obj. 2).

Duration: $\quad$ February/March, October, July and annually for life of project.

\section{Reports}

1. Prepare and submit monthly progress reports to BPA, Power Planning Council, and other interested parties.

Product: Monthly progress reports.

Level of Effort: 1 day completion of data, 1 day for writing report, 1 day typing.

Duration: Due end of each month.

2. Prepare and submit annual report to BPA, Council, and other interested parties 
Product: Annual report

Level of Effort: 1 month for compilation of data, 1 month for draft, 1 week for final, 1 week for preparation of manuscript

Duration: Draft report due October 31 each year; Final report due January 31 each year.

\subsection{Budget}

The wildlife mitigation project to replace a portion of habitat losses due to Grand Coulee Dam is budgeted below in two parts. Acquisition of leases will be through establishment of a trust fund over time. This will be the only cost to Bonneville. A discussion of this follows below under Section 5.6.1. Costs to run the program will be reimbursed from interest generated by the trust fund. Any extra funds generated from the trust account beyond those needed for operating and maintaining the lease and for monitoring progress will be used to conduct additional wildlife mitigation on the Spokane Reservation, which will then be credited to ratepayers. These costs are reported below for accounting purposes in Section 5.6.2.

A general cost summary of the two parts is listed below:

Cost to BPA

(1) Lease Cost

$\$ 3,548,100$

\section{Interest Income}

(1) Annual Trust Fund Interest Income (at year 8)

$\$ 257,342$

Cost Paid by Interest Generated by Trust Fund

(1) Baseline surveys (year 1)

(2) Implementation and development costs (years I-8)

$\$ 44,630$

(3) Operations and maintenance (annually)

$\$ 642,050$

$\$ 68,200$

(5) Foregone timber revenue harvest paid to tribe (after year 8)

$\$ 108,300$ 


\subsubsection{Trust Funding}

It is proposed that: (1) BPA pay the Spokane Tribe for a wildlife conservation easement on 5400 acres of tribal land. This will ensure that the land is managed for wildlife as opposed to other purposes; (2) the cost of the lease will be based on the potential timber harvest because the tribe will have to forego a portion of their timber revenues in order to manage the lease for wildlife rather than timber harvest. This is a least cost way of calculating the worth of the leased land. Other options include a proportion of purchase which would cost considerably more; and (3) easement costs will be used to establish a trust fund. The trust fund would generate interest that would be used to implement and develop the project and to perpetually fund (a) operation and maintenance, (b) monitoring and (c) repaying the tribe for lost timber harvest opportunities on the lease. Several benefits result.

Tribal trust lands are involved. Acquisition of land will not be necessary. The funds will therefore compensate the tribe for lost timber harvest and grazing opportunities, as well as perpetually generating funding for expenses of the mitigation project. In addition interest will accrue beyond project obligations. This will be used for reinvestment to help maintain the monetary value of the trust fund at a stable level relative to inflation. Any additional remaining funds will be applied to additional wildlife mitigation work on the reservation, which will be credited to ratepayers. Therefore, once implementation of this project is complete (estimated at 8 years), then the Spokane Tribe can begin looking at the additional losses, possibly without additional funding obligations by BPA and ratepayers. This represents a best "least cost" way to achieve the long-term biological objectives of habitat mitigation, and clearly illustrates an endpoint to funding.

Standing timber was computed by BIA forestry on 16 parcels within the project (Spokane Agency 1990). Nine parcels were considered to have commercial timber value. These are upland sites on the east and west side of the project. Microsites here are cooler and moister, favoring timber growth rates at approximately 235 board feet/acre/year. Existing timber on these parcels is estimated at 16.4 million board feet. Raw land (without timber) value was computed by BIA Realty at $\$ 100-150 /$ acre. The remaining given parcels have commercial timber present but at lower stocking densities making dollar harvest returns marginal. This land is elevationally lower, with west aspects along the river. Warmer and drier, shrub steppe and open forest/shrub habitats result. The land is classed as 
Rural acreage - Investment, at $\$ 125-450 /$ acre. It is of higher value due to its proximaty to the river.

To compute a lease value, two items need to be considered: timber and land values. Land is mostly within tribal trust. As such it is not on an open market exposed to potential development unless the tribe decides otherwise. About $8 \%$ of the area is in allotments, held in trust by the U.S. Government for individuals or families. Income also occurs through timber harvest on this land type, but to the individual/family. At this time it is uncertain if these lands would be included in the project dependant on the wishes of allottees. It is the tribes' goal to return individual allotments to trust for the benefit of all tribal members. Acquisition is only by willing seller. Two types of allotted lands are present: commercial timber land and lakeside. To prevent development incompatible with wildlife, the allottees will be offered market value for their land, including timber rights. There is 360 acres of lakeside land with an average value of $\$ 350 /$ acre, or $\$ 126,000$ worth of land. There is 160 acres of commercial timberland in allotments, at $\$ 150 /$ acre it is work $\$ 24,000$.

Timber value is the basis for the lease estimate. There are commercial volumes suitable for harvest on 9 of 16 parcels. This amounts to standing volume of $16,434,000$ board feet. The annual growth also needs to be summed with existing volume, for each year of the lease. There are 3842 acres in this category, producing $235 \mathrm{bf} / \mathrm{acre} / \mathrm{year}$, for 902,870 board feet annual increment. There will be some timber harvested for wildlife purposes through commercial thinning programs. The purpose is to enhance aspen and riparian zones, create open meadows, and enhance growth rates to speed development to mature and old growth stages. These harvest activities will rapture an estimated $20 \%$ of annual increment. Subtracting this commercial volume (903,000 bf $\times 20 \%$ ) from annual increment results in corrected annual growth addition of 722,400 $\mathrm{bf} / \mathrm{year}$.

The major commercial tree species is Ponderosa Pine. In the past two years its value per thousand board feet has varied from $\$ 150$ to $\$ 300$. This variability must be considered. to do this, the proposed trust fund will pay the tribe at the previous years timber value rate. This will be done prior to withdrawal for management needs. However, for purposes of figuring a trust fund a value of $\$ 185$ /thousand board feet is used below. 
Current value of Ponderosa pine, the major project species, is $\$ 150 /$ thousand bf (mbf). Value of existing standing and new annual growth then is:
Existing Commercial Timber: $16,434,000$
bf $\times \$ 125 / \mathrm{mbf}=\$ 3,040,290$
Annual Commercial Increment: 722,400
bf $\times \$ 185 / \mathrm{mbf}=\$ 133,644$

We propose that since the land is in tribal trust, BPA could purchase the lease over a period of years instead of at one time, which would provide BPA with some flexibility in funding. Easement payments could be in equal sums over the 8 year life of project implementation and development. The annual cost will include $\$ 380,000$ for existing Timber value plus $\$ 133,644$ for the annual commercial production increment foregone. At this point BPA obligations to the project will be terminated. Funding of the project will come from interest generated from the trust. A payment schedule is presented in Table 14 below.

Over an 8 year trust buidling period, the total cost would be $(8 \mathrm{x}$ $\$ 133,644)+\$ 3,040,290$ or $\$ 4,109,442$. Alternatively, if BPA wanted to reduce costs further, they could purchase the lease in a lump sum at a total cost of existing timber value of $\$ 3,040,290$.

\section{Table 14. Payments from Bonneville to Tribal Trust Fund by year of project, and interest generated for project operations.}

\begin{tabular}{|c|c|c|c|c|c|c|c|c|}
\hline Cumulative Standing & Year 1 & Year 2 & Year 3 & Year 4 & Year 5 & Year 6 & Year 7 & Year 8+ \\
\hline Timber Payments & 380.00 & 760,000 & $1,140,001$ & $, 520,001$ & $1,900,000$ & $2,280,000$ & $2,660,000$ & $3,040,00 \mathrm{C}$ \\
\hline $\begin{array}{l}\text { Foregone Annual } \\
\text { Production Revenues }\end{array}$ & 133,64 & 133,644 & 133,644 & 133,644 & 133,644 & 133,644 & 133,644 & 133,644 \\
\hline Cumulative Year & 513,64 & 393,644 & $1,273,644$ & $, 653,644$ & $\therefore, 033,644$ & $2,413,644$ & $2,793,644$ & $3,173,644$ \\
\hline $\begin{array}{l}\text { Interest Gener } \\
(@ 9 \%)\end{array}$ & $46.22 \varepsilon$ & 80,428 & 114,628 & 148.828 & 183,028 & 217.228 & 251,428 & 285,628 \\
\hline
\end{tabular}

1 Mean Annual Increment

\subsubsection{Project Implementation, Monitoring and 0 \& M Costs.}

Trust fund interest income will be used to pay project costs under the following five categories. 


\subsubsection{Baseline Surveys (Objective 2)}

These are initial measures of wildlife populations on the project area to be used to judge changes and trends over the project life. Air flights to count winter deer populations, pellet group counts $(2 \mathrm{x} / \mathrm{yr})$, grouse transects and total counts of furbearers and breeding waterfowl will be conducted. Also vegetation cover mapping will be conducted. Baseline data will be collected during the first two years of the project.

Salaries

Biologist (1 FTE @ 27,000/yr)

Benefits (@ 23\%)

Overhead (@32\%)

Mileage (@1000 miles x \$.28/mi)

Supplies (Binoculars, misc.)

Air Flight (@3 hrs x \$500/hr)

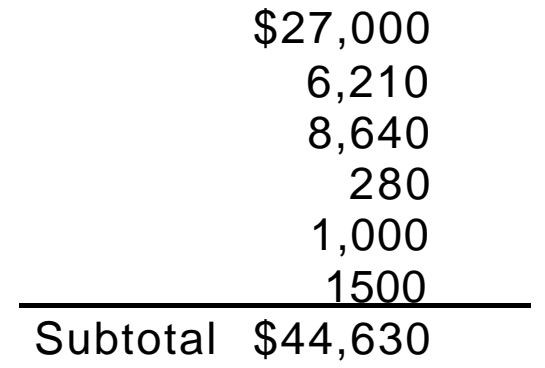

\subsubsection{Implementation and Development Costs}

Implementation is activities and costs associated with real estate, and will be completed in the first year (year 1). Specific elements and associated costs are:

Objective 1: Acquire Easement

Formal Appraisal

Survey

Title Insurance

Contracted and Legal Services
$\$ 4,500$

25,000

3,500

\section{Objective 2: Development/Inventory}

Subtotal $\$ 35,800$

Development costs are associated with land management and improvement. They will be conducted over 7 years (years 2-8). A project biologist will be needed to implement, develop and oversee all objectives.

Labor: 1 Biologist over 7 years

\begin{tabular}{lr} 
Salary - @ \$30,000/yr & $\$ 204,000$ \\
Benefits - @ 23\% & 46,690 \\
Overhead - @ 40\% & 81,200 \\
Travel - 6000 miles @ \$.28/mile & 11,760 \\
Supplies - @ \$2500/yr & 17.504 \\
\cline { 2 - 2 } & Subtotal $\$ 361,150$
\end{tabular}


Objective 3 - Livestock

Livestock Fencing: 6 miles fence @ \$5000/mile $\$ 30,000$

Cattleguards: 3 guards @ \$3,500/guard $\quad 10.500$

Objective 4 - Silviculture

Subtotal $\$ 40,500$

To be completed by Biologist and BIA Forestry within duties of project staff. It is anticipated that this item will be self-sustaining.

Objective 5 - Weed Control, grass and shrub restoration

Weed Control: 200 acres x \$20/acre \$4,000

Reseed native grasses and legumes:

50 acres/year $\times 4$ years $\times \$ 80 /$ acre $\quad 16,000$

Burn ceanothus:

100 acres/year x 6 years $\times$ \$15/acre $\quad 9,000$

Restore shrub steppe:

50 acres/year $\times 4$ years $\times$ \$500/acre 100,000

Fertilize grass, legumes, shrubs:

150 acres $\times 6$ years $\times \$ 15 /$ acre 13,500

Spring development:

10 sites $\times \$ 2,000 /$ site

20,000
Subtotal $\$ 162,500$

Objective 6 - Aspen Restoration,

Release cutting/burning:

20 acres/year $\times 5$ years $x$ \$200/acre $\$ 20,000$

Planting: 20 acres/year $\times 5$ years $\times \$ 250 /$ acre 25.000

Subtotal $\$ 45,000$

Objective 7 - Access Management

Road Gates: 10 gates x \$700/gate $\$ 7,000$

Seed Roads: 20 acres x \$80/acre 1,600

Road Barriers: 22 barriers x \$200/barrier $\quad 4,400$

Subtotal $\$ 13,000$

Objective 8 - Pool Creation

Geomorpholigical Profile of stream: no charge -0 -

Pool Construction: 10 pools

i) Oyachen Creek: x $\$ 2000 /$ pool

ii) Blue Creek: No charge - 0 -

Objective 9 - Sharp-tailed Grouse Restoration

Release: 50 birds/year x 3 years $\times \$ 150 /$ bird $\$ 22.500$ Implementation and Development Subtotal: $\$ 642,050$ 


\subsubsection{Monitoring (Objective 10)}

Monitoring of population and habitat changes will begin in year three and continue throughout the project as part of project biologist duties. At the completion of habitat development in year 8, a full assessment of results will be made. Objective responsibilities and costs will be included in Project Biologist duties (Objective 2).

\subsubsection{Annual Operations and Maintenance}

Beginning in year 9 and all outlying years, operations and maintenance will need to be funded. This will allow benefits to be maintained, and adjusted due to results of monitoring. A part time manager will be needed to conduct 0 \& $M$ with input from the biologist conducting monitoring.

Labor: 1.0 Manager @ \$27,000/yr

Benefits@23\%

$\$ 27,000$

Overhead@ @0\%

2,990

5,200

1,600

Travel: 5,000 miles@ @ \$.32/mile

9,000

Supplies: $\$ 9,000 / y r$

Equipment Leases and Rentals + 300 hrs @ \$50/hr

15.000

Subtotal

$\$ 60,790$

\subsubsection{Annual repayment to Spokane Tribe for lost timber harvest (after year 8)}

Annual Payment Cost (after year 8)

$\$ 133.644$

Subtotal \$133,644


TABLE 15. COST BY AND OBJ ECTIVE BY YEAR OF PROJ ECT.

\begin{tabular}{|c|c|c|c|c|c|c|c|c|c|}
\hline \multicolumn{10}{|c|}{ Cost by Year } \\
\hline Objective & 1 & 2 & 3 & 4 & 5 & 6 & 7 & 8 & $9+$ \\
\hline Implement & & & & & & & & & \\
\hline real estate & 35,800 & & & & & & & & \\
\hline Development/ & & & & & & & & & \\
\hline inventory & 51,093 & 51,593 & 51,593 & 51,593 & 51,593 & 51,593 & 51,593 & 51,593 & 51,593 \\
\hline Livestock & & 17,500 & 10,500 & 12,500 & & & & & \\
\hline Silviculture & & Antic & pate costs & $s=$ Reven & ues, i.e. $\mathrm{s}$ & elf-sustain & ing & & \\
\hline Weed control & & & 2,000 & 2,000 & & & & & \\
\hline Reseed grass/forbs & & & 4,000 & 4.000 & 4,000 & 4,000 & & & \\
\hline Burn & & & 1,500 & 1,500 & 1,500 & 1,500 & 1,500 & 1,500 & \\
\hline Restore shrub steppe & & & 20,000 & 25,000 & 25,000 & 25,000 & 5,000 & & \\
\hline Fertilize & & & 2.250 & 2.250 & 2,250 & 2,250 & 2,250 & 2,250 & \\
\hline Spring development & & 10,000 & 2.000 & 2,000 & 2.000 & 2,000 & 2,000 & & \\
\hline Aspen management & & 9.000 & 9,000 & 9,000 & 9,000 & 9,000 & & & \\
\hline Access management & & 7,000 & 4,400 & 1,600 & & & & & \\
\hline Pool creation & & & & 20,000 & & & & & \\
\hline Sharptail restoration & & & & & & 7,500 & 7,500 & 7.500 & \\
\hline 10: Annually monitor & & & Costs in & cluded in & Dbjective 2 & above. & & & \\
\hline Annual O \& M & & & & & 60,790 & 60,790 & 60,790 & 60,790 & 60.790 \\
\hline $\begin{array}{l}\text { Repayment to Tribe for } \\
\text { foregone timber revenue }\end{array}$ & & & & & & & & & 133,644 \\
\hline Total by Year & 86,893 & 95,093 & 107,243 & 131,443 & 156.133 & 163,633 & 130,633 & 123,633 & 246,027 \\
\hline
\end{tabular}




\subsection{SOURCES}

\subsection{LITERATURE}

Armleder, H.M.; Dawson, R.J. and Thomson, R.N. 1986. Handbood for timber and mule deer management coordination on winter ranges in the Cariboo Forest Region. B.C. Ministry of Forests, Victoria.

Beckstead, M. 1985. Roads vs wildlife. Washington Wildlife. 37:4-8.

Bergerud, A.T. 1988. Increasing the numbers of grouse. Ch. 16 in Adaptive strategies and population ecology of northern grouse. Univ. of Minnesota Press, Minneapolis.

Bodurtha, T.S.; Peek, J.M. and Lauer, J.L. 1989. Mule deer habitat use related to succession in a bunchgrass community J.. Wildl. Manage $53(2): 314.319$.

Brittingham, M.C. 1986 Spokane Indian Reservation Wildlife Questionnaire. Upper Columbia United Tribes, East. Wash. Univ., Cheney.

DeByle, N.V. 1985. Wildlife. Pgs. 135-152 in DeByle, N.V. and Winekur, R.P. eds. Aspen: Ecology and Management in the Western United States. USDA For, Serv. Tech. Rep. RM-119.

Griffith, B. and Peek, J.M. 1989. Mule deer use of aerial stage and habitat type in bitterbrush communities. J. Wildl. Manage 53(3):636-642.

Howells, R.G. 1986. Guide to techniques for establishing woody and herbaceous vegetation in the fluctuation zones of Texas reservoirs. Texas Parks and Wildlife Dept., Austin.

Leege, T.A. 1984. Guidelines for evaluating and managing summer elk habitat in northern Idaho. Id. Fish and Game Dept., Coeur d'Alene, 38 $\mathrm{pp}$.

Lyon, L.J. 1975. Coordinating forestry and elk management in Montana: Initial recommendations. Trans. N. Amer. Wildl. Conf. 40:193-201.

1979. Habitat effectiveness for elk as influenced by roads and cover. J. For. 77: 658-660. 
$198 \quad 3$. Road density models describing habitat effectiveness for elk. J. For. 81(9):592-593.

McLanahan, E.; Peone, T.; Brown, D.; Chess, D.; and Scholz, A. 1989. Aerial survey of deer populations on the Spokane Indian Reservation February 1989. Upper Col. United Tribes, East. Wash. Univ., Cheney.

Merker, C. and Scholz, A. 1990. Spokane Tribe of Indians wildlife mitigation and restoration for Grand Coulee Dam. UCUT Tech. Rep. \#4. East. Wash. Univ., Cheney.

Nichols, R., Nellis, C.H. and Kuck, L. 1986. It's time to manage elk and people. Idaho Wildlife. 6: 4-7.

Perry, C., and Overly, R. 1977. Impacts of roads on big game distribution in portions of the Blue Mountains of Washington, 1972-1973. Appl. Res. Sect. Bulletin \#11, Washington Game Dept., Olympia, WA. 39 p.

Roberts, R.F.; Kelemon, B.S.; Zamora, B.A. 1989. Evenage bitterbrush through prescribed fire: a management philosophy prescribed fire in the Intermountain Region: forest site preparation and range improvement: symposium proceedings Washington State University Cooperative Extension, Pullman, Wa. pp. 147-I 49.

Rogers, R. Restoration of sharp-tailed grouse in western Kansas. Kansas Department of Wildlife and Parks. Unpublished annual reports 198188.

Salt, G.W. 1957. An analysis of avifaunus in the Teton Mountains and Jackson Hole, Wyoming. The Condor 59(6): 373-393.

Shirato, M. and Watson K. 1990. The green dot road closure method: Evaluation and recommendation. Washington Department of Wildlife, Olympia.

Spokane Agency. Realty Branch Consultation to C. Merker memorandum dated 3/5/90.

Thomas, J.W. ed. 1979. Wildlife habitats in managed forests -the Blue Mountains of Oregon and Washington USDA Forest Service Ag. Handbook No. 553. 
Washington Department of Wildlife 1986. Wildlife protection, mitigation and enhancement planning for Grand Coulee Dam, Olympia, WA.

Witmer, G.W., and deCalesta, D.S. 1985. Effect of forest roads on habitat use by Roosevelt elk. Northwest Science. 59: 122-I 25.

\subsection{PERSONAL COMMUNICATION}

Brittingham, M.C. Wildlife Biologist. Pennsylvania State University. University Park, PA.

Hancock, D. Hancock House Publishers, Sarrey, B.C., Canada. pers. communication.

Hensold, T. Forester, Bureau of Indian Affairs, Spokane Agency, Wellpinit, Washington. 
7.0 APPENDICES 


\subsection{APPENDIX}

\subsection{Criteria required to be addressed in Mitigation Plans under NPPC's Wildlife Mitigation Rule}

\section{(A) Must complement the activities of the region's state and federal wildlife agencies and Indian tribes, and in particular how the plans would complement agency or tribal policies or programs to protect or enhance natural ecosystems and species diversity over the long term.}

The Spokane Tribe of Indians has a long history of wildlife use in the Upper Columbia River watershed. An archaeological site on the Spokane Reservation was recently discovered at the site of the Galbraith Springs Kokanee Hatchery and was radio carbon-dated at 2310 years before present (1950 as base year) (Galm, pers somm.). Therefore, the site was active at least as for back as 360 B.C. Use and permanent settlement of the area, and dependence on fish and wildlife is clear and proven. Defo (1883), a cadasteral surveyor who surveyed the boundary of the Spokane Reservation along the south bank of the Spokane River in 1883, reported that, "[the river] abounds with salmon...and trout are abundant...Game is plentiful along the river."

Anadromous fish and once abundant big game resources created a subsistence economy were use for ceremonial purposes. Anadromous fish are now extirpated. Big game, while still present, are much reduced due in part to habitat losses through reservoir flooding. In order to maintain and ultimately increase all wildlife species, including the big game resource base for the economic and cultural uses by the tribe, a Tribal Wildlife Committee was formed. Composed of tribal members, its purpose is to assure that wildlife is truly considered in governmental land use policies. Wildlife on the Spokane Reservation is accorded equal or top priority in the decision process for any land use decision. Wildlife is not simply allotted "by-product" status. The importance of wildlife to the general members was illustrated in the recently completed Integrated Resource Management Plan. Of 34 priority issues identified by tribal members, wildlife was a primary concern in ten. Wise use of all natural resources, including fish, timber, wildlife, and agriculture were primary concerns in 24 of 34 issues.

Loss of deer winter range is of great concern throughout the western states. However, losses in Washington may be especially great due to 
higher human population densities with associated development. In Eastern Washington it is considered a "critical wildlife habitat" under the state's Timber/Fish/Wildlife Agreement. Deer are a species of special concern to the tribe because they are hunted for subsistence. The unemployment rate on the Reservation is $64 \%$, and the average family income is only $50 \%$ of the average personal income off-reservation (L. Goodrow, pers. comm.). Thus subsistence use of deer and other big game is a very important economic consideration to the tribe. Yet a population survey and harvest estimate clearly shows a shortage of supply versus demand (McLanahan and Scholz 1989). A survey by Brittingham (1986) indicated $70 \%$ of tribal families have at least 1 member who hunts, as compared to the general population of about $7-10 \%$ (Brad Wood,WDW pers. comm.). Only $44 \%$ of tribal members were successful in killing a deer in 1986.

Much of the proposed easement has an overstory cover of scattered Ponderosa Pine, and a dense understory of bitterbrush, a preferred deer winter food source. The riparian habitat along the creek is welldeveloped and has even greater potential. By improving these types, deer populations can be expected to increase for at least two reasons: more deer will survive until spring, and those does using the unit can be expected to be more reproductively fit and productive.

\section{(B) Are the least costly way to achieve a biological objective (expressed in habitat units protected, mitigated, or enhanced)}

The entire proposed easement is on tribal land and so within tribal trust. Costs associated with acquisition (negotiation, title searches, and legal fees) will therefore be minimized.

An advance design management plan has been drafted. No special funding is needed for Advanced Design. Management costs are expected to be minimal. Fencing will be a primary tool to control free-ranging livestock. Timber harvest will be used only to meet wildlife objectives. Some forage (grasses and shrubs) planting will occur. An aspen management plan will be implemented to enhance this desirable species. Sagebrush will be planted in a portion of the area to enhance sharp-tail grouse.

The management of 4,400 acres of the 10,590 needed for full mitigation, will meet $41.5 \%$ of the Spokane Tribal goal. Expressed as 
Habitat Units replaced (3321) versus full mitigation (6670), this project will replace $49.7 \%$ of the Spokane's losses.

\section{HABITAT UNIT TYPE}

Ruffed Grouse

White-tailed Deer

Riparian Shrub

Total HU's
NOW
PRESENT

779

793

47
WITH
IMPROVEMENT

1,558

3,170

212

\section{NET INCREASE}

779

2,377

$\frac{165}{3301}$

We compared implementation costs per habitat unit between the four projects proposed for the Spokane Reservation to compensate for losses on the Spokane Reservation caused by Grand Coulee Dam mitigation objectives. The four projects in order of priority were:

Project 1: Protect and develop $3301 \mathrm{HU}$ 's of winter range, shrub steppe and riparian shrub.

Project 2: Protect or replace, and rehabilitate 1565 HU's of agricultural/shrub-steppe.

Project 3: Protect and develop $991 \mathrm{HU}$ 's of shrub steppe and transition forest.

Project 4: Protect and develop $768 \mathrm{HU}$ 's of forested riparian/wetland habitat.

A fifth project, riverine nesting islands, was not included as Habitat Units were not used as the accounting measure. Estimates are in 1990 dollars.

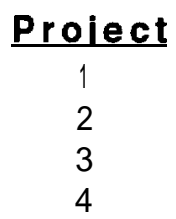

$\underline{\text { cost }}$

$\$ 2,573,420-\$ 3,548,100$
$\$ 1,780,000-\$ 2,250,000$
$\$ 1,910,000-\$ 2,110,830$
$\$ 1,371,190-\$ 1,606,180$

$\underline{\mathrm{HU}}$

3,301

1,565

991

768
Dollars/HU

$\$ 774-\$ 1,068$

$\$ 1,137-\$ 1,421^{\star}$

$\$ 1,927-\$ 2,130^{\star}$

$\$ 1,785-\$ 2,091$

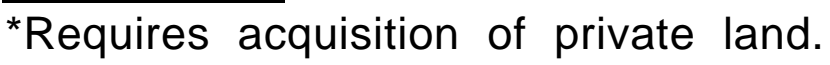

As can be seen, project 1, ( the proposed project) is cheaper per Habitat Unit than all others and did not require acquisition of private land.

To further reduce costs a trust fund will be established using easement fees (See 3.2 Trust Fund). This trust fund will allow perpetual operation and maintenance of the project without any further BPA funding. All three of the other proposed projects would require annual 0 \& $M$ 
funding. In addition it will allow the Spokane Tribe to begin mitigating Habitat Units beyond the NPPC IO-year interim goal, again without further BPA funding, which will be credited to ratepayers.

\section{(C) Protect or enhance special habitat or species that would not be available unless prompt action is taken.}

Proposed mitigation lands are in tribal trust so are not imminently threatened with land conversion development. However, without mitigation the lands will be included in the Forest Planning process. Logging may then result in the next 5 years which would compromise wildlife potential. Livestock grazing will continue to degrade the habitat. Expansion of deer, elk, and moose populations will be curtailed. Losses to wildlife suffered by the tribe over the past 50 years would continue.

Deer are a species of special concern to the Tribe for economic and cultural purposes. Failure to implement the project will prevent recovery of the two deer species. The proposed shrub steppe restoration, if not implemented, will preclude opportunities for sharp-tailed grouse reintroduction. The grouse is classified as a Sensitive Species by U.S. Fish and Wildlife Service (1982) due to great declines in habitat and population. Enhancement of both bald and golden eagles will be foreclosed as logging will continue to prevent the maturation of the forest. Eagles are federally classified as threatened. The opportunity to greatly enhance the wild resident trout on the Spokane Arm of FDR Reservoir will also be foreclosed.

\section{(D) Encourage the formation of partnerships with other persons or entities, which would reduce project costs, increase benefits and/or eliminate duplicative activities.}

The mitigation project would be cooperative effort among agencies, entities and individuals. The Bureau of Indian Affairs forest planner and forestry crew will be involved in all planning efforts, implementation and $0 \& M$ activities. They will assist with layout, timber cruising, and impact analysis. through the life of the project. BIA resource specialists will assist in designing and implementing livestock management goals. The Spokane Tribal Forestry crew will assist with custom cutting, shrub and tree planting, and road management. The Spokane Tribal Wildlife Committee and Spokane Tribal Council will review and give direction to the entire process. The UCUT wildlife biologist will assist a tribal biologist in the initial implementation phases. Since the UCUT biologist 
is funded through a federal appropriation, there will be no cost to hydroelectric ratepayers for this service.

In addition, students who are tribal members at Eastern Washington University, Department of Biology, will assist in culturing planting stock. Within the greenhouse in the new science wing, students will acquire, grow in containers, and outplant within the mitigation project, shrub and tree species. They will also assist in implementing the monitoring program. Costs will therefore be further minimized. We also plan to involve Indian high school students from Wellpinit and Hunters High Schools in this project.

(E) Have measurable objectives, such as the restoration of a given number of habitat units as represented in Table 5 of the rule;

The Grand Coulee losses were accepted by the NPPC as basis for initial mitigation efforts in the Columbia River Basin. Within those accepted losses, are 6679 Habitat Units within Spokane Tribal jurisdiction. These losses are summarized by indicator species in the table below from WDW (1986), and reported in total in Table 5 of the Mitigation Rule.

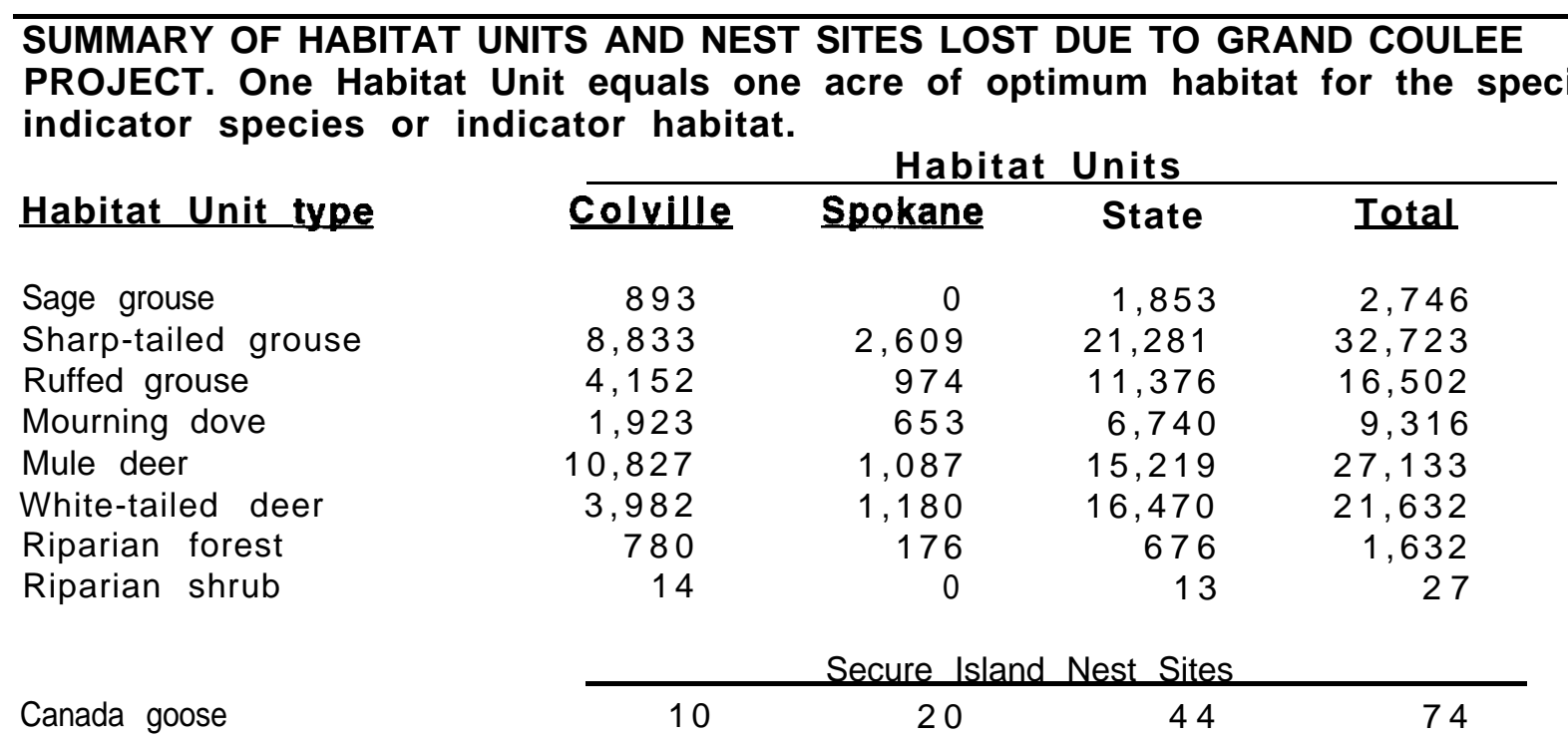

We are proposing to replace 3,321 of the 6,679 lost habitat units on the Spokane Indian Reservation. 


\section{(F) Not impose on Bonneville the funding responsibilities of others, as prohibited by section $4(h)(10)(A)$ of the Northwest Power Act.}

This plan imposes no funding responsibilities on Bonneville, except that as required under the Northwest Power Act. The wildlife losses resulted from construction of a federal dam in the Columbia River hydroelectric system i.e., Grand Coulee Dam, which caused the highest wildlife losses in the entire system. At Grand Coulee, hydropower revenue is repaying $92 \%$ of the project. The mitigation project is designed to replace $50 \%$ of the habitat losses over the 10 year interim period. Although this is somewhat higher than the Council's $35 \%$ goal basin wide, we believe it is a reasonable expectation for the tribe since the tribe has received no mitigation for lost wildlife habitat owing to Grand Coulee Dam, whereas the states have already received considerable compensation for wildlife losses for several of the federal dams on the system.

\section{(G) Address special wildlife losses in areas that formerly had salmon and steelhead runs that were eliminated by hydroelectric projects (for example, societal and tribal wildlife losses)}

The presence of the Spokane Indian people at the location which is now their reservation is not merely a coincidence. The tribe repeatedly declined the U.S. governments attempts to relocate them on reservations in Montana and Idaho, arguing that the Spokane and Columbia Rivers were their principle hunting and fishing grounds. Reservation boundaries on the south bank of the Spokane River and the west bank of the Columbia, were specifically established to allow the tribe to maintain control of their historic and highly valued fisheries on these rivers.

With the building of Grand Coulee Dam and the subsequent elimination of the saimonid runs to the Upper Columbia and Spokane Rivers and all associated tributary streams, wildlife has become even more important to the Spokane way of life.

Completion of Grand Coulee Dam totally blocked Upper Columbia River anadromous fishes in 1939. Riparian and adjacent upland wildlife habitat losses were extensive as inundation occurred through 1941. BPA fish and "wildlife" mitigation to date in the Columbia system has been almost totally targeted towards lower river anadromous fish. Little resident fish and wildlife mitigation has occurred, especially in the Upper basin. Although a kokanee hatchery for the Spokane Reservation is 
currently in the Council's program, construction has not yet started, and that hatchery will not remotely mitigate the tribe for economic losses suffered as a result of loss of fish and wildlife resources owing to hydroelectric development (i.e., cumulative loss of approximate $\$ 1.5$ billion as of 1989). The Spokane Tribe has therefore suffered for almost 50 years without any mitigation benefits.

\section{(H) Protect high quality, native, or other habitat or species of special concern, whether at the project site or not, including endangered, threatened, or sensitive species.}

The perennial creek within the project is the best remaining wild rainbow spawning tributary to Lake Roosevelt on the Reservation. Potential to enhance this population through riparian zone management is great.

The project unit is high quality deer winter range that is important to a disproportionate percentage of the reservation deer herd. Aerial winter counts have identified the proposed leased lands as one of two most important wintering areas on the Reservation (McLanahan et al. 1989 and Brittingham and Scholz 1986). Results suggest that the numbers of mule deer are remaining relatively stable or slightly lower (173 in 1989 compared to 196 in 1986). Conversely, the population of white-tailed deer appears to have declined sharply from 768 in 1986 to 213 in 1989. Total deer counts were therefore down $60-76 \%$ in 1989. Even at the higher indicated population levels of 1986, hunter success levels were only $44 \%$, i.e. $56 \%$ of hunters were unsuccessful in this priority tribal activity.

Deer populations are certainly of special concern to the Spokane Tribe. As compared to the general population of the state where $7-10 \%$ of the general population hunts, a larger percentage of tribal members engage in hunting with $70 \%$ of families having at least one hunter (B. Wood, WDW, pers. comm; Brittingham 1986). Deer hunting as a subsistence activity was rated the number one wildlife priority by tribal members (Brittingham 1986).

Other big game species of importance are resident black bear, and increasing moose and Rocky Mountain elk populations. The former is a shy species, quite susceptible to harassment without access management. Moose and elk populations will not reach their potential unless proposed management is implemented. Expanded deciduous habitat management, primarily aspen and riparian zones, will help their populations. 
Shrub-steppe restoration and management is proposed for the western, lower and drier, portion of the unit will benefit sharp-tail grouse, which is listed as a sensitive species. Bitterbrush/sagebrush/riparian draw restoration is proposed. Washington has lost $60 \%$ of this habitat type (B. Rodrick, WDW, pers. comm.). Declines in associated wildlife populations have also been great. Bald eagle and golden eagle will benefit from the planned timber management on the proposed lease. Both species are listed on the $\mathrm{T}$ and $\mathrm{E}$ list.

\section{(1) Provide riparian or other habitat that may benefit both fish and wildlife}

The Creek within the unit is perennial and supports wild resident rainbow trout. it also is the most important spawning tributary for wild Lake Roosevelt-run rainbow on the Reservation. Though it has a narrow riparian zone, sitka alder is well-developed. Pools will be constructed to encourage beaver. Beaver activity will help modify the zone in a positive way for both wildlife and fish. Creative riparian zone management will encourage a host of upland, riparian and wetland dependant species over a wide area of the unit.

Within the 1987 Columbia River Basin Fish and Wildlife Program, under Section 903 (g)(I)(D) Lake Roosevelt Resident Fish Substitution is addressed; specifically, tributary stream spawning and rearing habitat for rainbow trout. The proposed mitigation project will enhance the efforts of the tribe to meet this measure. The wildlife mitigation project will reduce or eliminate the need for BPA to finance this work. Currently as part of the Tribal Fisheries Program, the tribe is conducting its own hydrogeological survey of potential habitat improvements in this tributary at no cost to BPA ratepayers.

\section{(J) Address concerns over additions to public land ownership and impacts on local communities, such as reduction or loss of local government tax base, special district tax base, or the local economic base; or consistency with local governments' comprehensive plans;}

Ninety-two percent of the land within the unit is owned and managed by the Spokane Tribe, with the remainder managed by the tribe for allottees. There is no private land, so acquisition will not be necessary. The land is within tribal trust and is managed for tribal benefits. The primary use at this time is income from timber harvest. The area is 
within two forest compartments. Livestock grazing also occurs and generates some tribal funding through grazing leases. These twb income generating activities would be subservient to a wildlife mitigation plan. This lost income would need to be replaced. This would be done through lease or easement payments.

The lands would remain in timber management zones as they are currently zoned in the tribal comprehensive plan. However, they would be removed from the timber base upon which allowable cut is determined. Cutting levels would therefore not increase outside the unit, following mitigation implementation.

(K) Use publicly-owned land for mitigation, or management agreements on private land, in preference to acquisition of private land, while providing permanent protection or enhancement of wildlife habitat in the most cost-effective manner

Land within the unit is currently in the tribal trust. No fee title acquisition is necessary. About $8 \%$ is allotted land managed in trust for named tribal members. Timber and grazing management occurs in allotted lands in the same manner as on trust lands. Income simple accrues to individuals rather than the tribe. Under a wildlife mitigation plan, lease income may replace resource-based income to individuals or the tribe. There would be no negative financial impacts to the individuals or the tribe under this system. There is no county taxable land here. Land within the unit would be dedicated to wildlife mitigation for 20400 years, as determined by the Tribal Council and Bonneville.

(L) Mitigate losses in-place, in-kind, where practical. When a wildlife measure is not directly related to a hydroelectric-caused loss, the habitat units protected, mitigated or enhanced by that measure will be credited against mitigation due for one or more hydroelectric projects, including power-related storage or regulatory dams.

This project mitigates losses in-place and in-kind. It is directly related to a federal hydroelectric project - - the Grand Coulee Dam. It should be credited against Grand Coulee Dam.

There are many references to the abundance of, and tribal dependance upon, the former wildlife populations along and adjacent to 
the Spokane River (reviewed by McLanahan et al. 1989). Deer were common in the former riparian bottomlands. This habitat is now gone. The mitigation project is designed to replace some of the winter range values lost in the reservoir flooding, with south-facing, bitterbrush hillsides immediately adjacent to, and overlooking, the impounded Spokane River. Mitigation would therefore be in-place. In would be in-kind for deer and other associated big game as well as some riparian forest losses. It would be in-kind for riparian habitat-type losses only to a small degree, as there are no longer opportunities to create or protect extensive riparian, riverine bottomlands. However the riparian habitat involved is the best that is remaining on the Reservation.

\section{(M) Help protect or enhance natural ecosystems and species diversity over the long term.}

The project is designed to assure protection by making timber harvest activities subservient to wildlife over the 20-100 year term. It is also designed to enhance habitat, thereby increasing species and habitat diversity and richness.

The unit has the potential to host a great diversity of habitats and species. The dry, west-facing river terrace slopes can support shrub steppe restoration. Bluebirds, shrikes, mule deer, and bald and golden eagles will benefit there. This habitat restoration will create favorable conditions for reintroduction of the extirpated Columbian sharp-tailed grouse. The middle uplands are primarily Ponderosa pine/shrub and bunchgrass. Establishment of scattered aspen stands will create an aspen mosaic of conifer and deciduous habitat. The aspen is expected to be disproportionately important to non-game birds, mule and white-tailed deer, elk, and ruffed grouse. Turkey will likely invade from the recent Washington Department of Wildlife introduction south of the river. The north slopes currently support dense Douglas fir-shrub conditions. Management here will encourage formation of large aspen stands, and rejuvenated red stem ceanothus. Benefits to all big game species including moose and black bear will occur. Riparian zone enhancement will benefit furbearers, ruffed grouse, forest waterfowl and resident salmonids.

\section{(N) Are based on, and supported by, the best available scientific knowledge}

The project is based upon the losses and mitigation needs as identified in: [Washington Department of Wildlife. 1986. Wildlife 
protection, mitigation and enhancement planning for Grand Coulee Dam, Olympia, WA. Final report submitted to: U.S. Department of Energy, Bonneville Power Administration. Contract No. DE-Al79-86BP60445. Project No. 86-74 August 1986]. The specific project area has been identified as one of the two most important deer winter range areas on the Spokane Reservation (Brittingham and Scholz 1986; McLanahan et al. 1989), and the most important tributary on the Spokane Reservation for producing wild resident rainbow trout that migrate into Lake Roosevelt (Upper Columbia United Tribes Fisheries Center, internal reports).

\subsection{SPOKANE TRIBE - GENERAL WILDLIFE GOALS}

Mitigation policy and management goals are presently being developed by the tribe. The general philosophy of the tribe is to:

1) Protect existing wildlife habitat and maintain maximum diversity of species.

2) Increase, through direct management or habitat protection using principles of adaptive management, the abundance of species which has been adversely affected by development, including hydropower facility construction and operation.

3) increase species which can be used by tribal members for subsistence hunting.

4) Maintain and manage species of important religious, cultural and economic significance to the Tribe.

5) Maintain viable populations of species which are currently threatened or endangered.

6) Coordinate wildlife goals with tribal range, forestry, fisheries, environmental quality and economic development plans, and the Integrated Resource Management Plan.

7) Reflect goals of tribal members as identified in 1986 wildlife questionnaire. 


\subsection{PUBLIC INVOLVEMENT PROCESS CERTIFICATION}

Tom Trulove, Chairman

Northwest Power Planning Council

851 SW Sixth, Suite 1100

Portland, OR 97204

Subject: Certification of Grand Coulee Dam mitigation public review process

Dear Chairman Trulove:

The Upper Columbia United Tribes, of which the Spokane Tribe is a member, has completed a public review process for the proposed Grand Coulee Dam wildlife mitigation. I believe we have met the obligations and objectives of the Northwest Power Planning Council's Wildlife Mitigation Rule.

Of the 111,711 wildlife habitat units lost owing to construction of Grand Coulee Dam, 6,679 were lost to the Spokane Indian Reservation. We have finalized goals as they apply to the tribe for losses of wildlife habitat on the Spokane Indian Reservation. Our goals are designed around conditions and opportunities as seen by the Tribe on its remaining land base.

In addition we have formulated a specific project to address the top goal of the Spokane Tribe. This project was discussed with the Tribal Council and all other groups that reviewed the goals. A review of the project was also conducted by the Columbia Basin Fish and Wildlife Authority (CBFWA) Wildlife Committee. It has been included as a CBFWA priority project for FY 1991. The projects' purpose is to replace winter range and riparian habitat units lost due to reservoir inundation. Increased habitat diversity, and habitat and sensitive species restorations are project goals. The project analysis showed it to be the most beneficial in terms of both benefit/cost ratio, and in terms of accrued habitat units. We have already completed an advance design for the project. It is enclosed for your review. The tribe is currently conducting a hydrogeology survey of the prennial creek on site. Our original purpose in conducting the hydrogeology survey was to identity habitat enhancement opportunities for wild rainbow trout that migrate between this tributary and Lake Roosevelt. We will now include wildlife habitat objectives within our hydrogeology parameters. 
Both the advance design and the hydrogeology survey have been, and will be completed by us at no cost to BPA. We hope you will recognize our commitment to the mitigation process and our desire to get started.

A public review document was created and is enclosed for your review. This document included a background of the Council's role and intent regarding wildlife mitigation, the methods used to identify losses at Grand Coulee, a summary of habitat impacts on the Spokane Reservation, a list of specific goals regarding Grand Coulee, and a list of both Tribal and Council standards and criteria by which to evaluate the specific mitigation goals.

This public review document was mailed to tribal officials, Bureau of Indian Affairs personnel, Lincoln and Stevens county commissioners. It was made available at the two public meetings held on the reservation. It was also available for discussion at a government consultation at the Spokane Airport, and two public review meetings in Davenport and Kettle Falls. The government consultation and latter two meetings were conducted by WDW with assistance by the Spokane and Colville Tribes. At the two public meetings on the Reservation, the government consultation in Spokane, and public review meetings in Davenport and Kettle Falls, the Spokane Tribe outlined not only its goals but also our top priority project to meet these goals.

Comments to the goals and project were accepted both verbally and in writing. A "Response to Comments" was developed and is included for your inspection.

Notification of tribal public hearings were advertised in the Spokane Spokesman Review newspaper. The advertisements were run in both Saturday and Sunday papers, as we believed that a greater audience would be reached on those days. A copy is included for your perusal.

Final tribal goals reflect tribal social and cultural needs and opportunities for habit restoration with the limited tribal trust land base on the reservation. Examples include: shrub steppe restoration, and protection and enhancement of riparian and deciduous forest habitat types. We believe this will lead to increased species diversity and ecosystem complexity. 
After reviewing the steps taken by UCUT and the Spokane Tribe I certify that we have completed the activities required by Council to fully allow public input and review of our goals and project.

For 50 years the Spokane Tribe has suffered significant social and cultural impacts associated with the loss of wildlife due to Grand Coulee habitat destruction. We are encouraged by the positive steps that you have taken to attempt restoration through your adoption of the Rule and an interim wildlife mitigation goal. It is now time to move forward with on-the-ground mitigation.

\author{
Sincerely, \\ Joe Flett \\ Spokane Tribal Chairman
}

Enclosures 


\title{
SPOKANE TRIBE OF INDIANS
}

\section{Response to Comments received during Formal \\ Public Review Process}

\author{
30 March 1990
}

INTRODUCTION

The Northwest Power Planning Council (NPPC) finalized the Wildlife Mitigation Rule in October 1989. It included preliminary identification of loses resulting from Grand Coulee Dam. The inundation of over 70,000 acres and loss of 151 miies of freeflowing river caused an estimated total loss of 111,711 habitat units of valuable wildlife habitat. The Spokane Tribe suffered a loss of 6,679 habitat units. The Spokane tribe developed generic wildlife and habitat goals to replace these losses. The criteria in Section 1003 (4)(B) calls for public involvement to discuss the appropriateness of these goals. The public involvement process required consultation with local government, public meetings to explain the process and goals, solicitation of comments regarding the goals, and responses to comments.

The Spokane Tribe has conducted the first. three steps of the public review process. Included below are responses to comments received during the review period. A list of public meetings in which the tribe participated, is included. Finally an attendance list from the on-Reservation meetings is also presented.

A package explaining the process, history of activities, estimate of habitat losses identified by the NPPC, prioritized tribal goal statements and mitigation plans was mailed, and discussed at public meetings (see enclosure). Public comments were requested.

All comments made and received by tribal members, both oral and written, recognized habitat losses as being real and negative to wildlife. One commentator stated:

"Our eider people of the tribe tell stories of how great the hunting and fishing was prior to construction of Grand Coulee. The Spokane tribal people have always been active hunters and fishermen who have depended on the wildlife as a way of subsistence. I would like 
to see habitat and wildlife populations returned to the way it used to be in the past so that my children can once again enjoy the pleasures of a prosperous hunting trip or fishing trip that their fathers and grandfathers we once used to."

Other commentators also referenced a desire to improve the area for their childrens benefit. The cultural importance of wildlife usage was mentioned as an important incentive.

Comment: Two commentators thought that the pacing of the goal, i.e., the $35 \%$ limitation to wildlife mitigation, was limited and too slow over the 10 year period. They thought that, as losses have accrued over 50 years, a mitigation goal of $50 \%$ or better of identified losses was more reasonable.

Response: NPPC set a 10 year interim goal to replace $35 \%$ of the identified habitat losses. This goal is a basin wide target. This can mean that more than $35 \%$ of losses can be mitigated at a specific hydro project. It is called an interim goal so as to measure progress and success of mitigation over the 10 year period. At the end of 10 years an opportunity to evaluate the results of the program, and to determine further needs will be made. In addition, NPPC stated that areas blocked to the upstream movement of anadromous fish should be addressed as special losses, so it is conceivable that more than $35 \%$ of the Grand Coulee losses would be mitigated for. below.

Comments from off-reservation, non-tribal people follow

Comment: One commentator (PNUCC) believed that the Spokane Tribe received compensation for inundated reservation lands. A one-time monetary payment, wildlife management rights on adjacent shoreline and fishing rights on Lake Roosevelt were cited as evidence of wildlife mitigation.

Response: In an act dated June 29, 1940 (54 stat 703), $16 \mathrm{U}$. S. C. sec. 8354 Congress required the Secretary of the Interior to designate Indian lands taken for Grand Coulee project, and granted itself rights, title and interest to those lands. No reference was made to monetary compensation. The Spokane Tribe never received any monetary payment as compensation for land condemnation due to reservoir flooding. More specifically, the Spokane Tribe never 
received any monetary payment for wildlife values lost on the inundated acres, which is a separate issue altogether.

As regards wildlife management rights on the reestablished shorelines, the executive order establishing the reservation, and the Act authorizing Grand Coulee Dam are very clear. The tribe had uncontested wildlife rights within the exterior reservation boundaries long prior to the reservoir flooding. Removing the productive riparian zone from tribal use, then claiming compensation is served by reconveying rights to the tribe on lessproductive hillsides, rights that were never "lost", is irrelevant to the Wildlife Mitigation Rule.

The same comments apply to fishing rights. "Regranting" fishing rights where they already existed has no bearing on wildlife mitigation.

Comment: Two references were made regarding tribal offreservation hunting, and hunting "all year round", especially for deer.

Response: This comment does not apply to the Spokane Tribe. The Spokane Tribe does not hunt off-reservation.

The Spokane Tribe has set seasons for all big game on reservation. The most liberal season are for buck deer and blackbear, which are 6 months. Elk season was recently closed for at least 2 years to allow a transplanted population time to settle and grow. Moose season is limited to bulls only.

Civil penalties for game law violations can be stringent. Revocation of hunting privileges are often enforced for violations.

in the proposed tribal mitigation lands access management will be implemented. Road closures, and seasonal refuges will be used to create undisturbed security zones for wildlife.

Comment: concern was expressed that in most cases when land is acquired for wildlife, subsequently, because of inadequate operation and maintenance funding, the land is poorly managed allowing for infiltration of noxious weeds such as knappweed, which reduce wildlife values. 
Response: We have suggested a mechanism for permanent 0 and $M$ funding by generating interest from a Trust account. Part of our management plan is aggressive control of noxious weeds. 


\section{SPOKANE TRIBE}

\section{Grand Coulee Wildlife Mitigation Meetings}

Following the acceptance of the Wildlife Mitigation Rule by the Northwest Power Planning Council in October 1989, the Spokane Tribe conducted and/or assisted with a series of meetings. We contacted resource agencies, local governments and the general public regarding the mitigation process and the Tribe's goals. A list of the meetings follows.

\begin{tabular}{|c|c|c|}
\hline Date & Place & Participants \\
\hline $10 / 30 / 89$ & Davenport & $\begin{array}{l}\text { Consultation with Senator Scott } \\
\text { Barr, Lincoln County Government } \\
\text { and public, Lake Roosevelt } \\
\text { Forum. }\end{array}$ \\
\hline $11 / 30 / 89$ & Spokane & $\begin{array}{l}\text { Brief of Rule with Spokane } \\
\text { Tribal Chairman. }\end{array}$ \\
\hline $12 / 12 / 89$ & Wellpinit & $\begin{array}{l}\text { Brief of Rule with Spokane } \\
\text { Tribal Council, Tribal Wildlife } \\
\text { Committee members: requested } \\
\text { input as to appropriateness of } \\
\text { goals. }\end{array}$ \\
\hline $12 / 27 / 89$ & Wellpinit & $\begin{array}{l}\text { Received input from Spokane } \\
\text { Tribal Wildlife Committee. }\end{array}$ \\
\hline $01 / 10 / 90$ & Wellpinit & $\begin{array}{l}\text { Tribal Council discussion and } \\
\text { ranking of goals. }\end{array}$ \\
\hline $01 / 13 / 90$ & Colville & $\begin{array}{l}\text { Consultation with state and } \\
\text { local government leaders and } \\
\text { interested citizens. }\end{array}$ \\
\hline $02 / 07 / 90$ & Spokane & $\begin{array}{l}\text { Local advisory consultation with } \\
\text { state and local government, } \\
\text { resource agencies and citizen } \\
\text { groups. }\end{array}$ \\
\hline $02 / 12 / 90$ & Davenport & Public Involvement Process. \\
\hline
\end{tabular}




\begin{tabular}{l|c|l} 
Date & Place & \multicolumn{1}{c}{ Participants } \\
\hline $02 / 13 / 90$ & Kettle Falls & Public Involvement Process. \\
$02 / 14 / 90$ & $\begin{array}{r}\text { Wellpinit, } \\
\text { West End } \\
\begin{array}{c}\text { Community } \\
\text { Center }\end{array}\end{array}$ & $\begin{array}{l}\text { Public involvement Process - 2 } \\
\text { meetings held on Spokane } \\
\text { Reservation. }\end{array}$ \\
$03 / 22 / 90$ & Davenport & $\begin{array}{l}\text { Local advisory consultation with } \\
\text { state and local government, } \\
\text { resource agencies and citizen } \\
\text { groups. }\end{array}$
\end{tabular}




\title{
BLUE CREEK RANGE \\ GRAND COULEE DAM WILDLIFE MITIGATION
}

\author{
HABITAT EVALUTION PROCEDURES
}

\author{
Modified Habitat Evaluation Procedures Workbook \\ Blue Creek Range \\ by: \\ Ronald L. Peters \\ Christopher Merker \\ Upper Columbia United Tribes \\ Fisheries \& Wildlife Research Center
}

Project Number 9 1-062 


\title{
HABITAT EVALUATION PROCEDURES BRIEFING PAMPHLET
}

\author{
BLUE CREEK RANGE \\ GRAND COULEE DAM WILDLIFE MITIGATION \\ Sept. 24,1991
}

PROJECT SCOPE

Conduct a baseline analysis of wildlife habitat values using the Habitat Evaluation Procedures(HEP).

\section{OBJECTIVES}

The objective is to rate the quality of the habitat for lands being considered for acquisition or management as mitigation for losses to wildlife due to damages caused by construction of Grand Coulee Dam.

\section{PROCEDURES}

1.) An interdisciplinary evaluation team will be assembled to conduct a site survey and collect data on habitat type, quantity, quality, and wildlife use under existing conditions.

2.) A "habitat suitability model" for each indicator species and a composite model will be provided. Each model will provide information and descriptions of key "life requisites" and graphs illustrating the relationships between these requisites(variables) and habitat quality.

3.) Based on this information, personal knowledge, professional judgment, and group discussion each member will rate the habitat as it relates to the given variables.

4.) Team members will discuss their ratings for the habitat variables. If they are widely different then the team member should discuss his/her rational for that decision.

5.) The teams rating for each variable shall be from the consensus all team members. If no consensus value can be agreed upon the value will be deferred to the team expert or a simple average of the teams ratings will be used. 


\section{INTRODUCTION}

The following habitat evaluation procedures models have been modified for the Blue Creek Winter Range wildlife mitigation project on the Spokane Indian Reservation. The target species considered in this manual are White-tailed Deer (Odocoileus virginiana), Sharp-tailed Grouse (Tympanuchus phasianellus columbianus), and beaver (Castor canadensis).

The white-tailed deer model focuses on two life requisites, food and cover. Both of the life requisites are divided into a set of three variables. The first three variables focus on different types of cover and the second three focus on different types of food and its availability. Either of these two life requisites can be limiting thus, the model is driven by the outcome of either set of variables.

In our sharptail model production drives the population, so nesting and brooding cover are most important. In the shrub steppe this means grass/forb (herbaceous) and shrub cover is of primary importance. We believe winter food is of secondary importance, while shrub and tall herbaceous plants will provide winter cover.

In our beaver model water and food drive the population. Cover and reproductive needs are assumed to be identical with water requirements. If any of the two life requisites are void the habitat is considered unsuitable for beaver. The model predicts that either of the two sets of variables can be considered limiting if they are not satisfied to a certain degree.

The models described in this manual are for all cover types found within the range of the individual species.

The object of this manual is to give you an opportunity to work with the models we are going to use, and to get an idea of what we are going to do in the field on September 24, 1991. I hope this is adequate for your needs at this time. I will be happy to answer any questions regarding the model format and variable descriptions. If you have questions or comments you may call me (Ron Peters) at 509-359-7049 between the hours of $10 \mathrm{am}$. and $5 \mathrm{pm}$. Monday Friday. 


\section{V1 HORIZONTAL CONCEALMENT}

Horizontal concealment (hiding cover) is considered to be optimim when $90 \%$ of an adult standing deer is hidden at distances equal to or less than 200 feet. The variable will be defined as the amount of a standing deer that is covered at 200 feet. If $80 \%$ or better is covered this will be considered optimum.

\section{V2 OVERSTORY CANOPY COVER}

Overstory or thermal cover is considered to be vegetation used by deer to help maintain comfortable body temperatures with minimal energy expenditure (Jagernan, 1984). Overstory canopy cover (thermal cover) is considered optimum if canopy closure is greater than $\mathbf{6 0 \%}$.The literature describes mean canopy closure of $70 \%$ to be optimum for areas in Northern Idaho, but values ranging from $50-70 \%$ for different areas have been reported.

\section{V3 WIDTH OF COVER}

If large openings or agricultural fields are in the habitat area the width of cover between the various openings or fields becomes important. An SI value of 1 is placed on this variable if the width of cover is greater than 400 feet. If the width of cover is less the value to white-tailed deer decreases (Kaumheimer, personnal comm.).

\section{V4 SHRUB CANOPY COVER}

Shrub cover refers to the \% coverage of shrubs, forbs, and grasses. This essentially determines the foraging potential for the deer. It has been reported that by fall deer were subsisting entirely on browse (Roberts, 1956; Jageman, 1984).

\section{V5 SHRUB COMPOSITION}

Shrub composition describes the type of browse present in an area. If an area is comprised of preferred browse species then it will receive a high rating. However, this does not have a lot of impact on the overall model equation because deer can survive on several different species of browse in any one location.

\section{V6 SHRUB DIVERSITY}

Shrub diversity is an important component to deer survival. Diversity will allow some food to be available in any situation. This is important for survival in the odd winter with exceptional amounts of snow, or extremly cold temperatures.

\section{V7 DENSITY OF OPEN ROAD PER SQ. MILE}

The relationship between miles of open road and potential deer use is such that O-1 mile/ sq. mile receives an SI value of $1.0,1-2$ miles $=0.8,2-3=0.6,3-4=0.4,4-6=0.2$, and anything equal to or greater than $6=0.0$.

\section{EQUATIONS}

The equations are based on certain life requisites. They are 1.) Food, and 2.) Cover. V1, V2, and V3 are cover variables. V4,V5, and V6 are food variables. V7 is a special road disturbance variable and is the only variable which can be limiting. The equation for determining the suitability index is as follows:

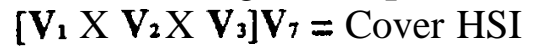

$$
\left[\left[2\left(V_{4}+V_{6}\right)+V_{5}\right] / 5\right] V_{7}=\text { Food HSI }
$$

The HSI rating for the individual cover types will be determined by figuring the equations (food vs cover) and whichever one is the lowest will be considered the limiting factor and will be the overall HSI. 
WHITE-TAILED DEER MODEL
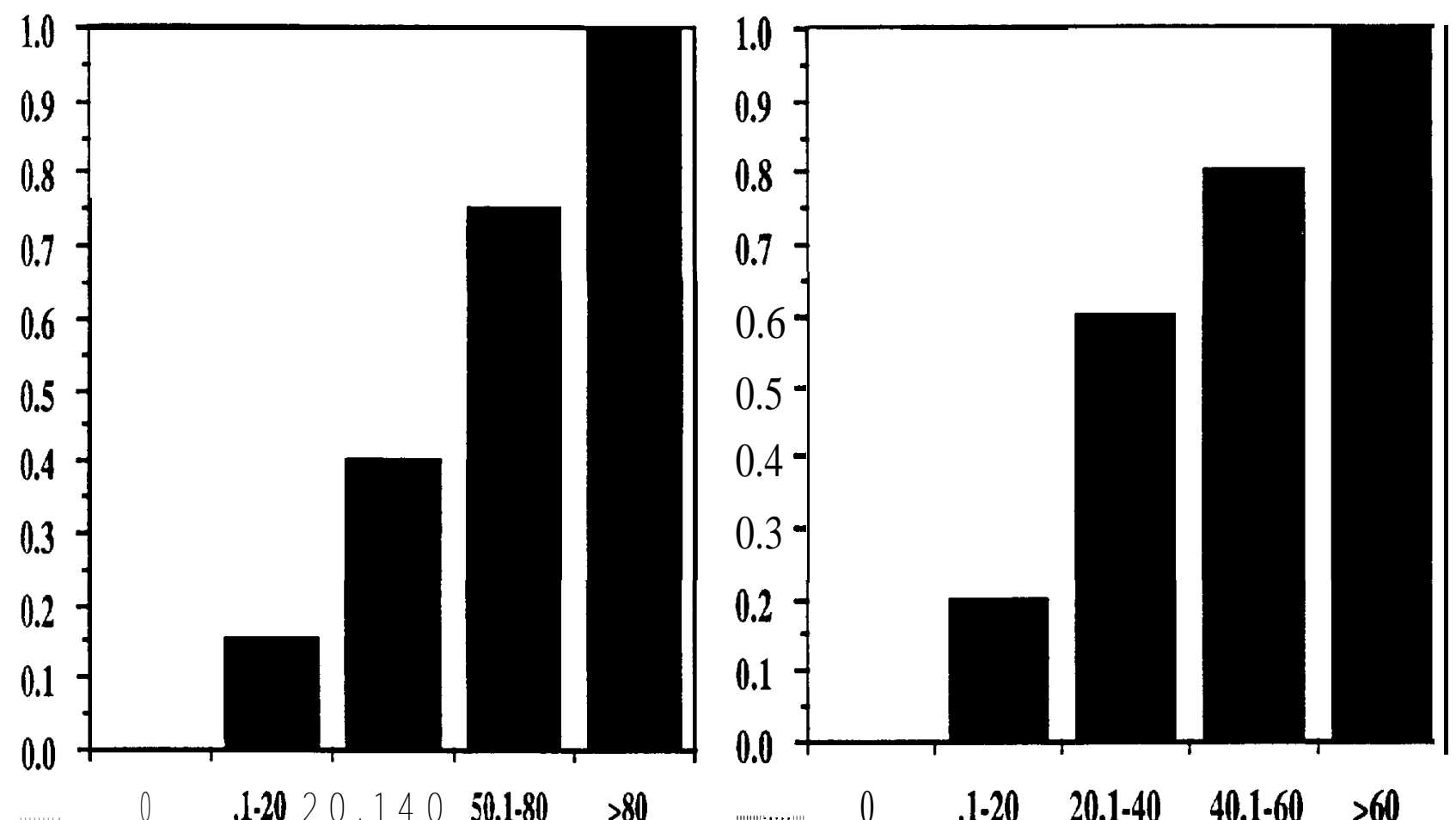

VI HORIZONTAL CONCEALMENT (\%)

$\begin{array}{lllll}0 & 1.20 & 20.1-40 & 40.1-60 & >60\end{array}$ OVERSTORY CANOPY COVER (\%)
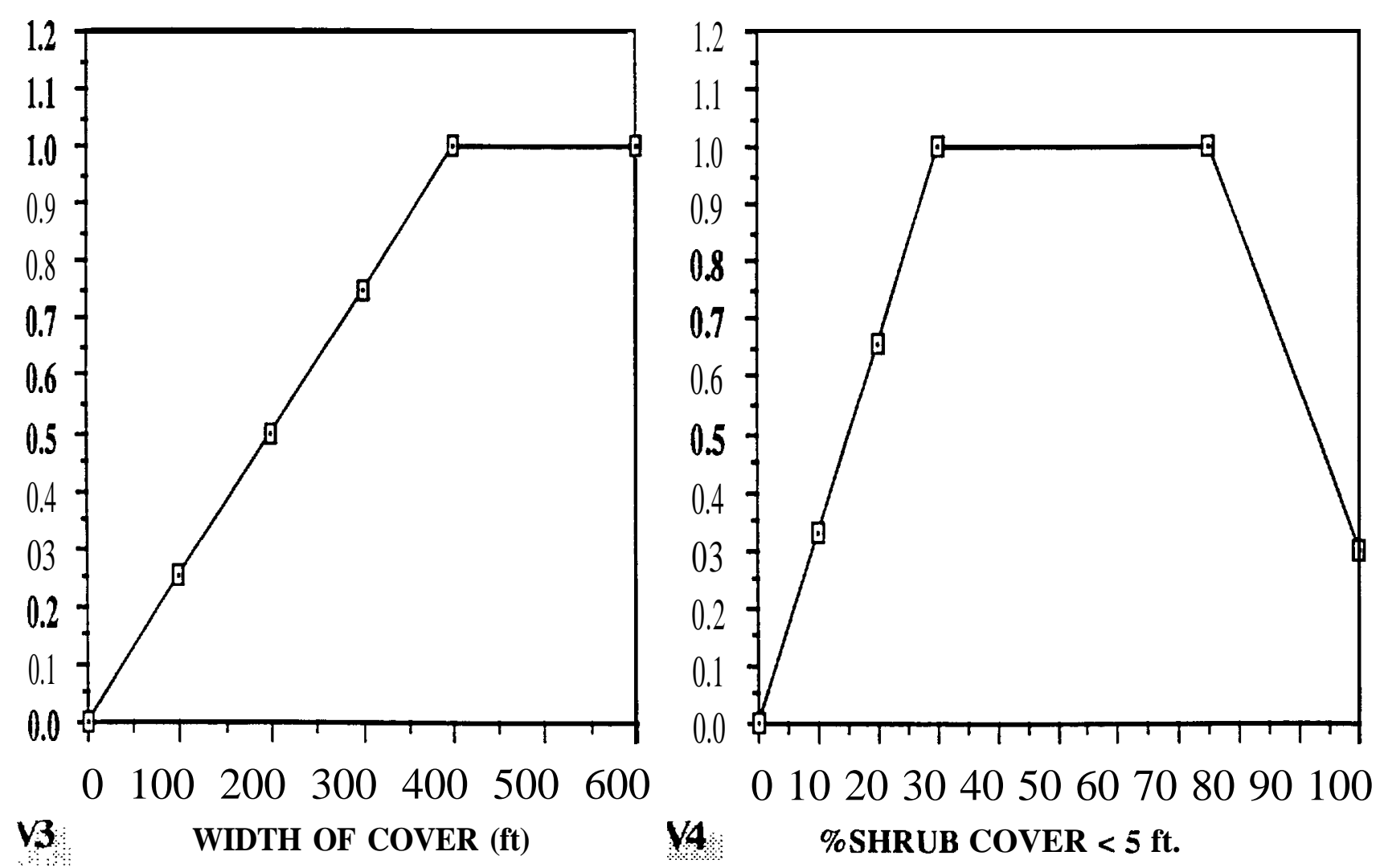
WHITE-TAILED DEER MODEL

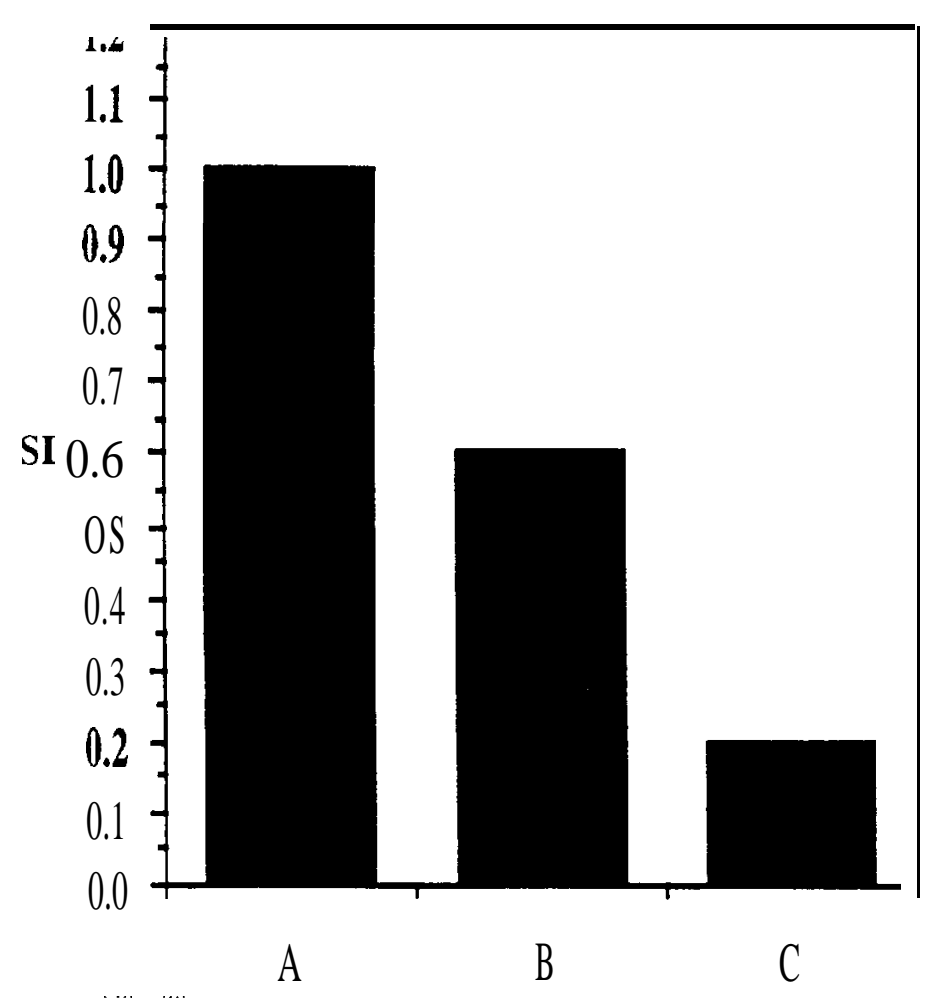

SHRUB COMPOSITION

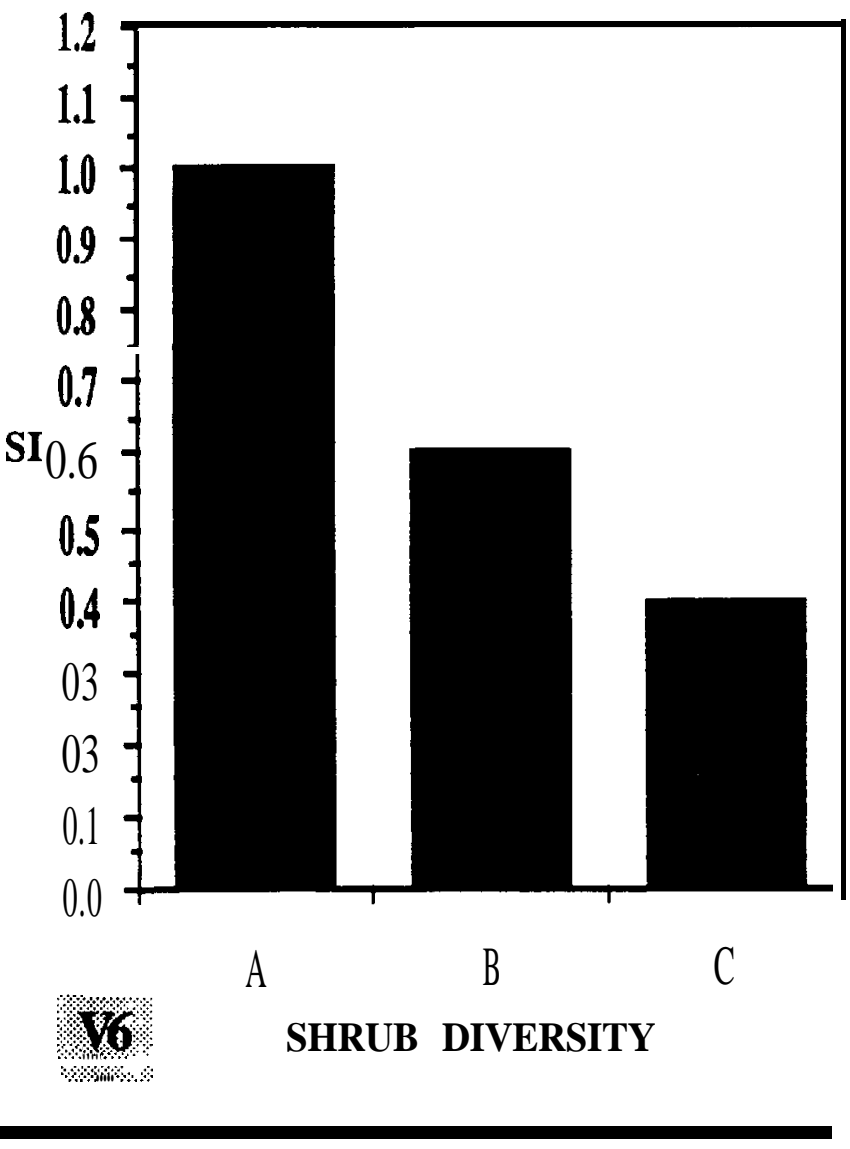

DETAILED DESCRIPTION OF GRAPHS

Shrub Composition

$A=$ Western Redcedar, Ceanothus,

Willow, Serviceberry, Chokecherry,

Red-osier dogwood, Maple,

Kinnikinnick, Oregon Grape

B= Cottonwood, Snowberry, Aspen,

Ponderosa Pine, Grand Fir, Hawthorn,

Spiraea, White Pine

C=Ninebark, Oceanspray,

Alder, Blackberry, Mockorange,

Lodgepole Pine, Elderberry, Menziesia,

Thimbleberry, Western Larch
Shrub Diversity

$A=3$ species

$B=2$ species

$C=1$ species 


\section{SHARP-TAILED GROUSE MODEL \\ DESCRIPTIONS OF VARIABLES AND GRAPHS}

\section{V1 \% SHRUB CROWN COVER}

Sharptails can exist without shrubs but prefer a mid percentage of shrub cover as optimal. Openings are important, especially for broods, so dense shrub is sub-optimal.

\section{V2 MEAN HEIGHT OF HERBACEOUS VEGETATION}

This is primarily a measure of secure nesting cover for hens. Eleven to twenty-five inches is optimum as it provides hiding cover, but is not so tall so as not to preclude rapid escape. Taller cover however still has value, especially to wintering birds. Hence, tall cover never goes to a SI value of 0.0 .

\section{V3 HERBACEOUS COVER}

Herbaceous cover is preferred for nesting, as well as brooding. Both forbs and insects are in high numbers, and available at ground level, for growing chicks and nesting hens. A preferred mid-range is optimum. The birds cannot exist without any herbacious cover, hence an $\mathrm{SI}=\mathbf{0 . 0}$. However they can exist in $100 \%$ grass/forb, i.e. without shrubs, but certainly not at optimum. Hence, we have set $100 \%$ cover at an $\mathrm{SI}=0.2$.

\section{V4 MEAN HEIGHT OF SHRUBS OR HERBS WHICHEVER IS GREATER}

Shrubs represent several things to sharptails. They offer some nest cover to hens, brood cover especially during hot summer days, escape cover, and food in the winter. Optimum $S I=1.0$ is at 5 feet or greater, primarily for effective cover and for food which will be above the snow in the winter. However, if the height of herbaceous vegetation is adequate for summer/winter cover then it will also be considered in this component of the the model.

\section{EQUATIONS}

The equation is a simple arithmetic mean. It is not weighted for any particular variables. We believe these birds are very adaptable given proper cover requirments. The equation is as follows:

$$
\frac{V_{1}+V_{2}+V_{3}+V_{4}}{4}=\text { HSI }
$$


SHRUB STEPPE- SUMMER AND WINTER RANGE
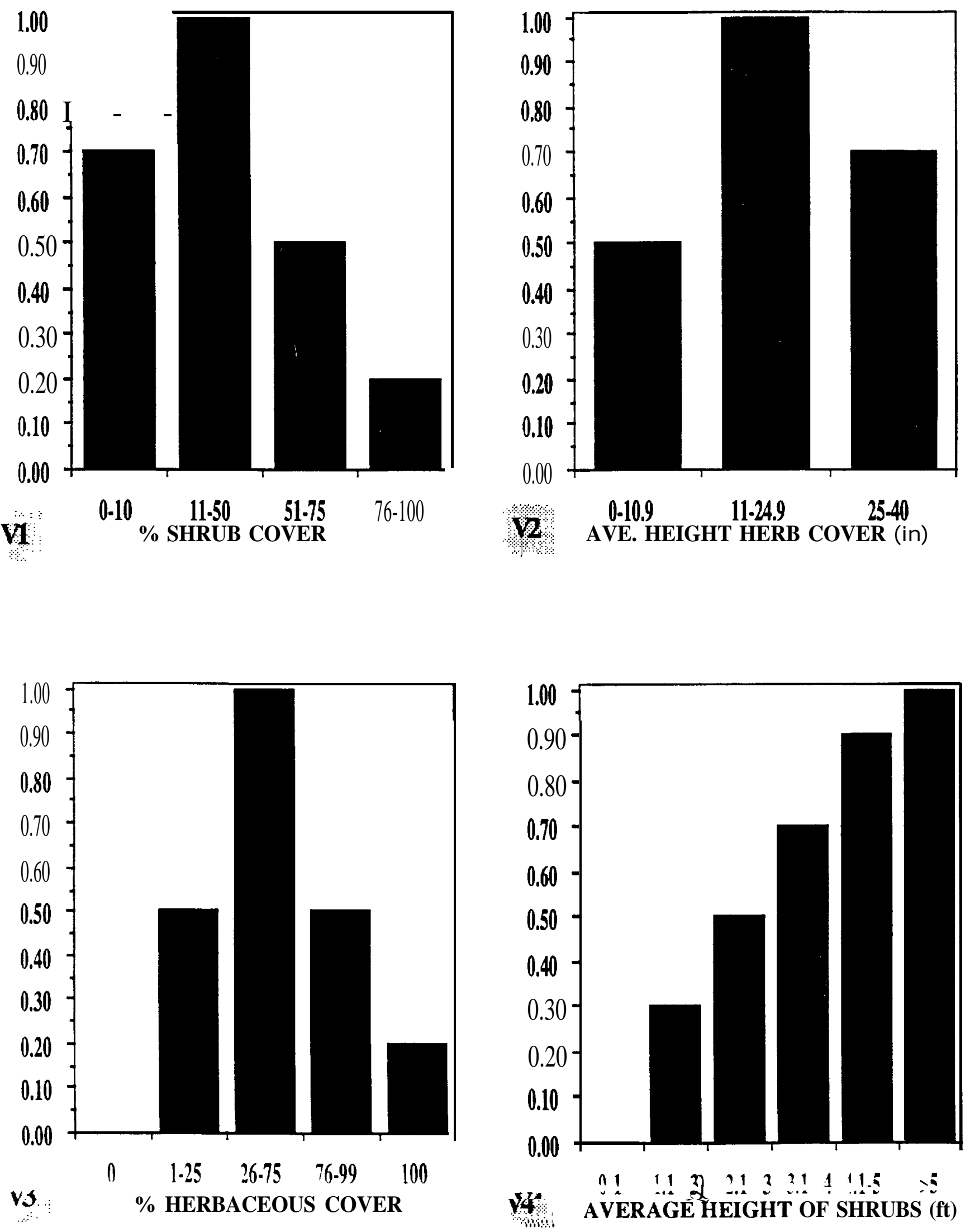


\section{BEAVER MODEL \\ DEFINITIONS OF VARIABLES}

\section{PERCENT TREE CANOPY CLOSURE}

The percent of the ground surface shaded by a vertical projection of the canopies of woody vegetation greater than or equal to $5 \mathrm{~m}(16.5 \mathrm{ft}$.) in height. It is assumed that a tree and/or shrub canopy closure between $\mathbf{4 0 - 6 0 \%}$ is an indication of optimum food availability (Allen, 1982). Stands with greater than $60 \%$ canopy closure are assumed to be less suitable due to the decreased accessibility of food. Extremely dense stands result in an increased likelihood of cut trees hanging up in adjacent trees (Allen, 1982).

\section{V2 PERCENT OF TREES IN THE 1-6 INCH SIZE CLASS}

Optimum dbh of trees should run between 1 and 6 inches. This seems to be the preferred size class. Larger trees are avoided generally unless nothing else is available.

\section{V3 PERCENT SHRUB CROWN COVER}

The percent of the ground shaded by a vertical projection of the canopies woody vegitation $<5 \mathrm{~m}$ (16.5 ft.) in height. Food value within a cover type is a function of density, size class, and species composition. Under some conditions shrubs of optimum size and density can provide an adequate amount of food during all seasons. It has been noted though that most use of shrubs occurrs just after green-up in the spring.

\section{V4 AVERAGE HEIGHT OF SHRUB CANOPY}

The average height from the ground surface to the top of those shrubs that comprise the uppermost shrub canopy. To be of optimum value shrubs should be at least $2 \mathrm{~m}$ tall.

\section{VS SPECIES COMPOSITION OF WOODY VEGETATION}

A.) Woody vegetation dominated (greater than or equal to $50 \%$ ) by one or more of the following species: aspen, willow, cottonwood, or alder.

B.) Woody vegetation dominated by other deciduous species.

C.) Woody vegetation dominated by coniferous species.

It has been shown that beaver show a preference to the types of woody tree stems utilized in a certain area. However, many different types of trees will be used but to varying degrees.

\section{V6 PERCENT STREAM GRADIENT}

The vertical drop in meters or feet per kilometer or mile of stream or river channel. Beavers can usually control water depth and flow, however, larger rivers or streams with a high gradient cannot be controlled and are considered unsuitable as beaver habitat (Allen, 1982).

\section{V7 AVERAGE WATER FLUCTUATION ON AN ANNUAL BASIS}

A.) Small fluctuations that have no effect on burrow or lodge entrances.

B.) Moderate fluctuations that effect burrow or lodge entrances.

C.) Extreme fluctuations or water absent during part of the year.

Beavers require a permanant supply or water and prefer a seasonably stable water level. This stable water level provides cover for feeding and reproduction. If water is absent at any time dur-

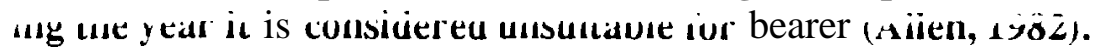


BEAVER

RIVERINE HABITAT MODEL

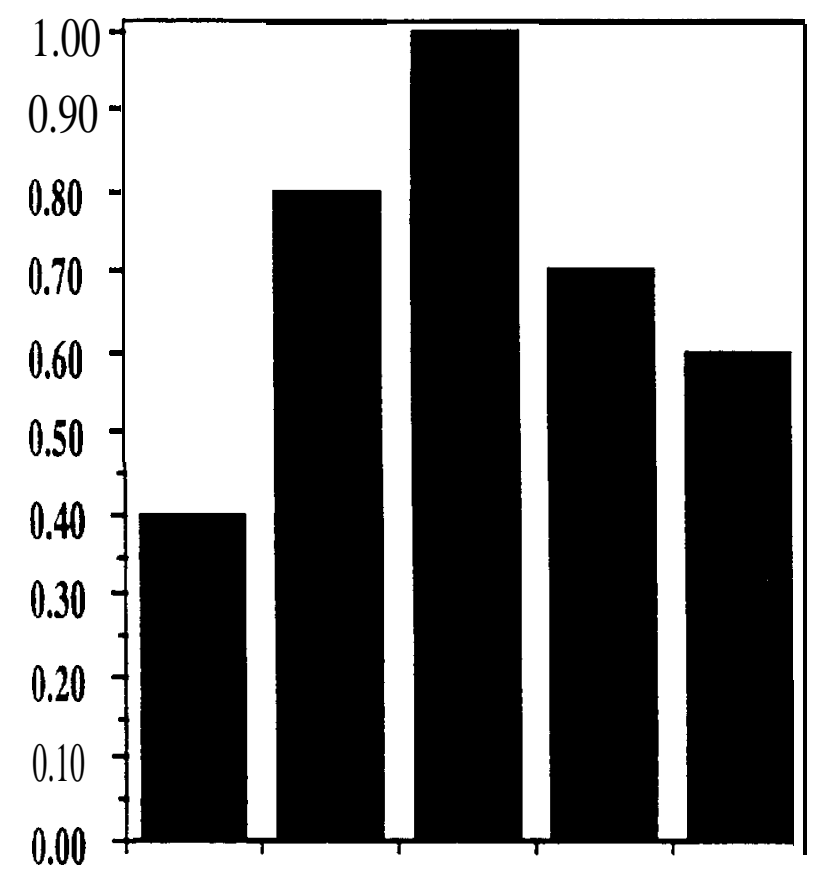

$\begin{array}{lllll}1.25 & 26.40 & 41.60 & 61.80 & 81.100\end{array}$ VI. PERCENT TREE CANOPY CLOSURE

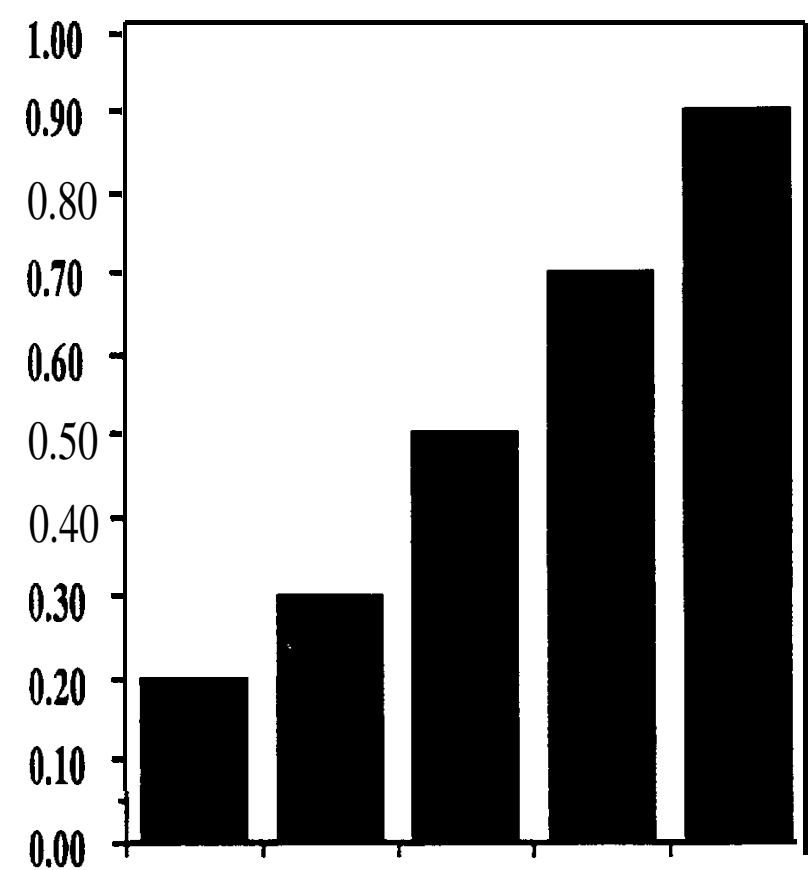

$\begin{array}{lllll}0 & 1.25 & 26.50 & 51.75 & 76-100\end{array}$ PERCENT OF TREES IN THE 1-6 INCH DBH SIZE CLASS

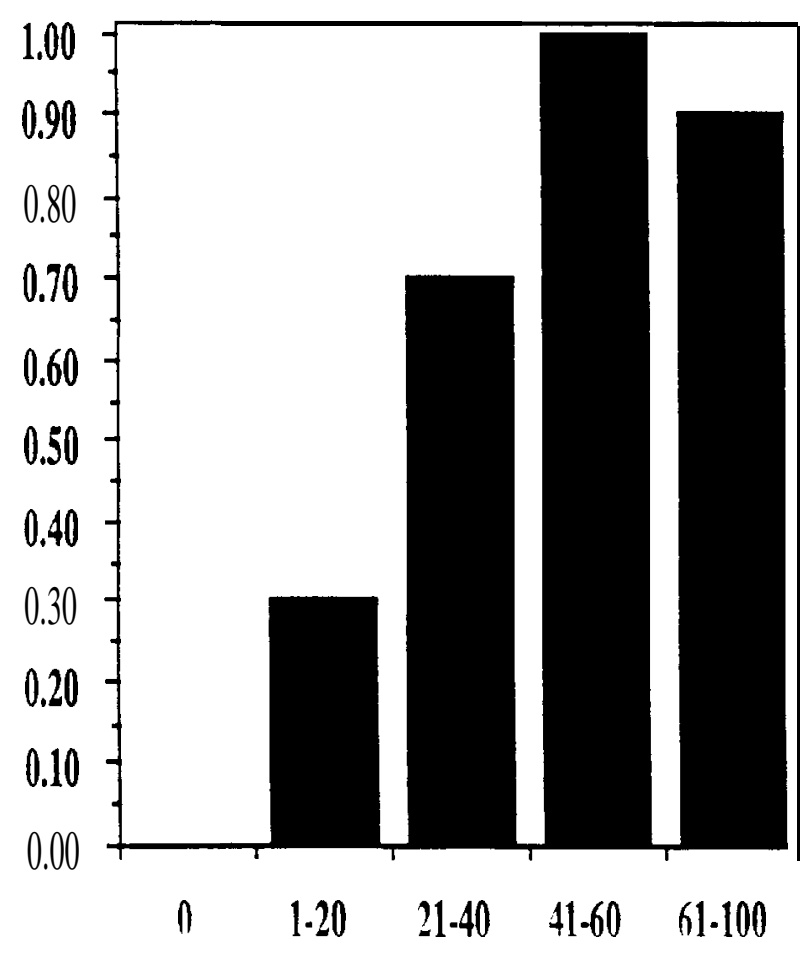

Y3 PERCENT SHRUB CROWN COVER

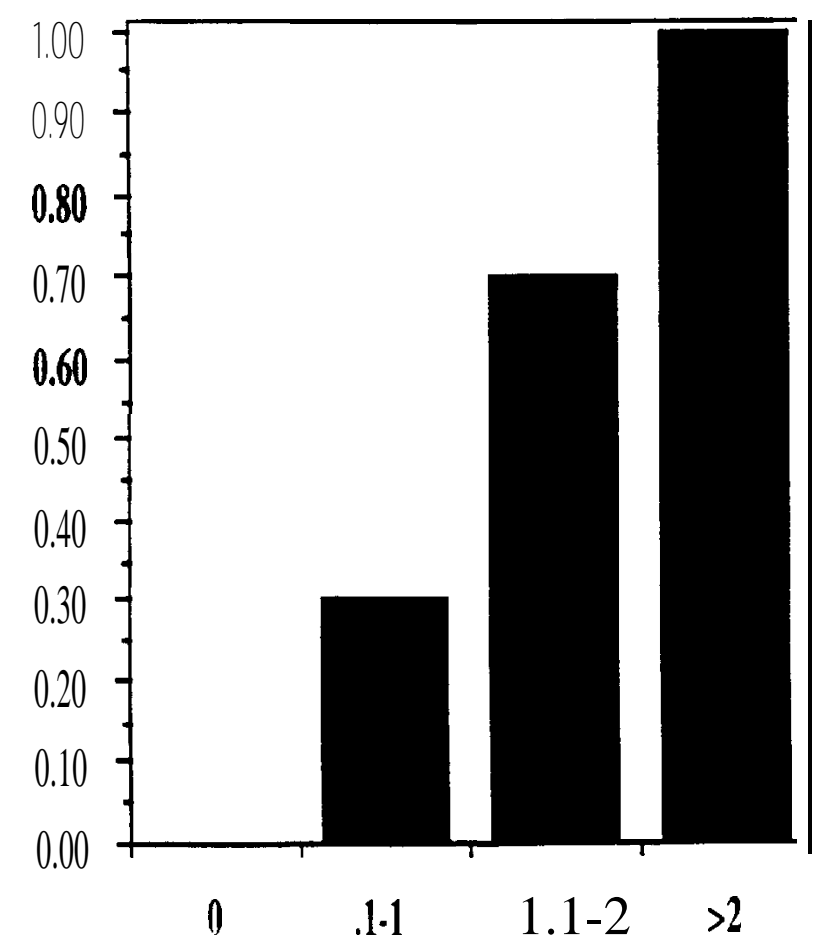

V4 AVERAGE HEIGHT OF SHRUB CANOPY 
BEAVER

RIVERINE HABITAT MODEL

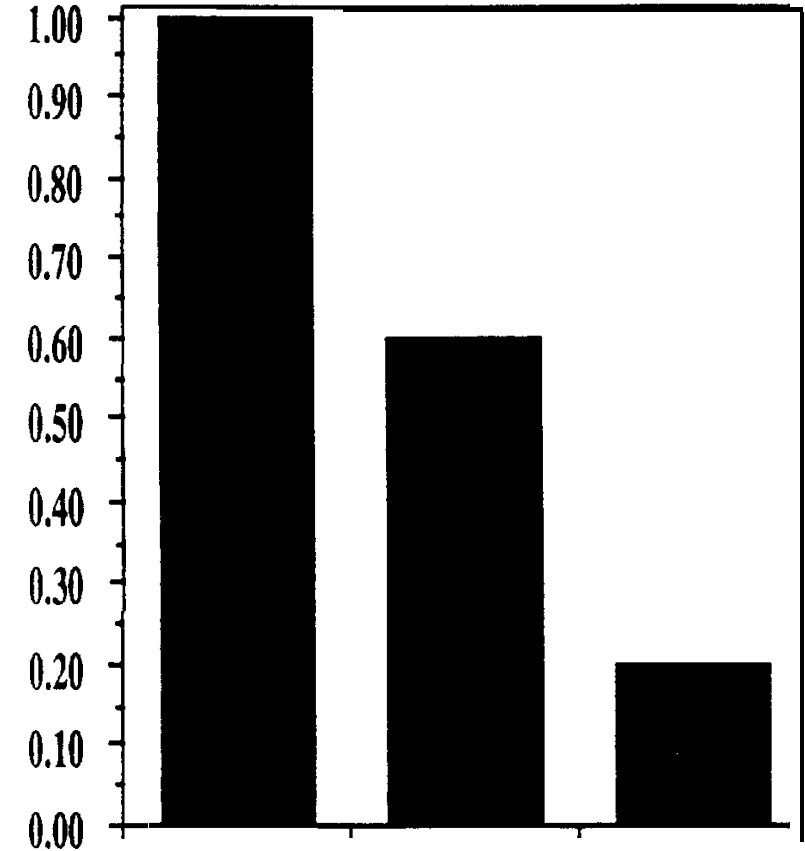

V5 $\stackrel{\text { A }}{\text { B }}$ SPECIES COMPOSITION OF WOODY VEGETATION (TREES AND/OR SHRUBS)

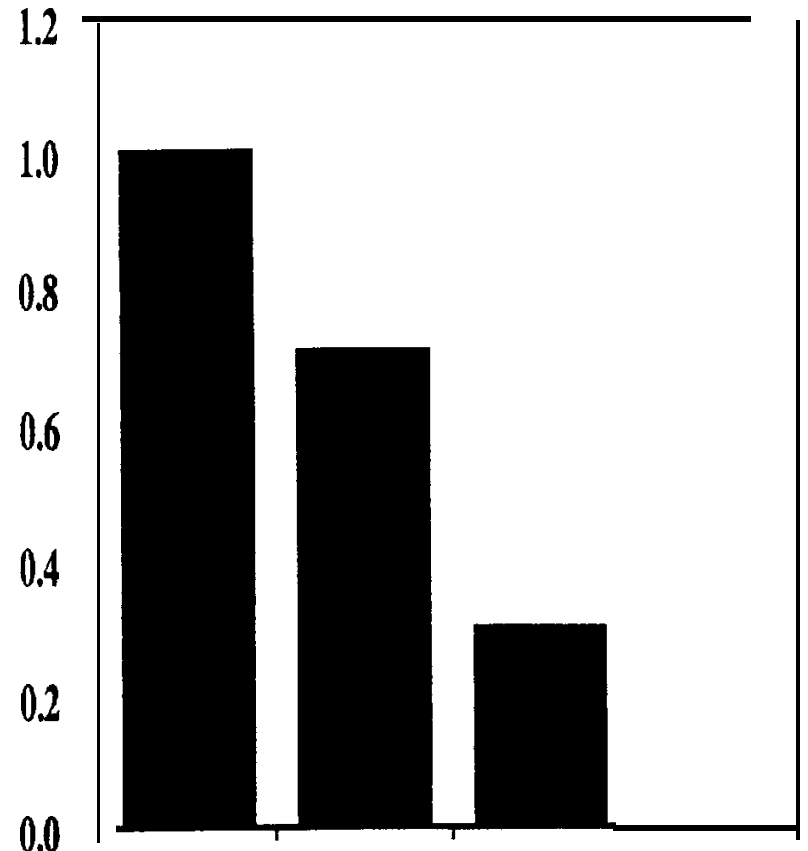

$\begin{array}{llll}<6 & 6-10 & 10.1-15 \quad>15\end{array}$ PERCENT STREAM GRADIENT

\section{EQUATIONS}

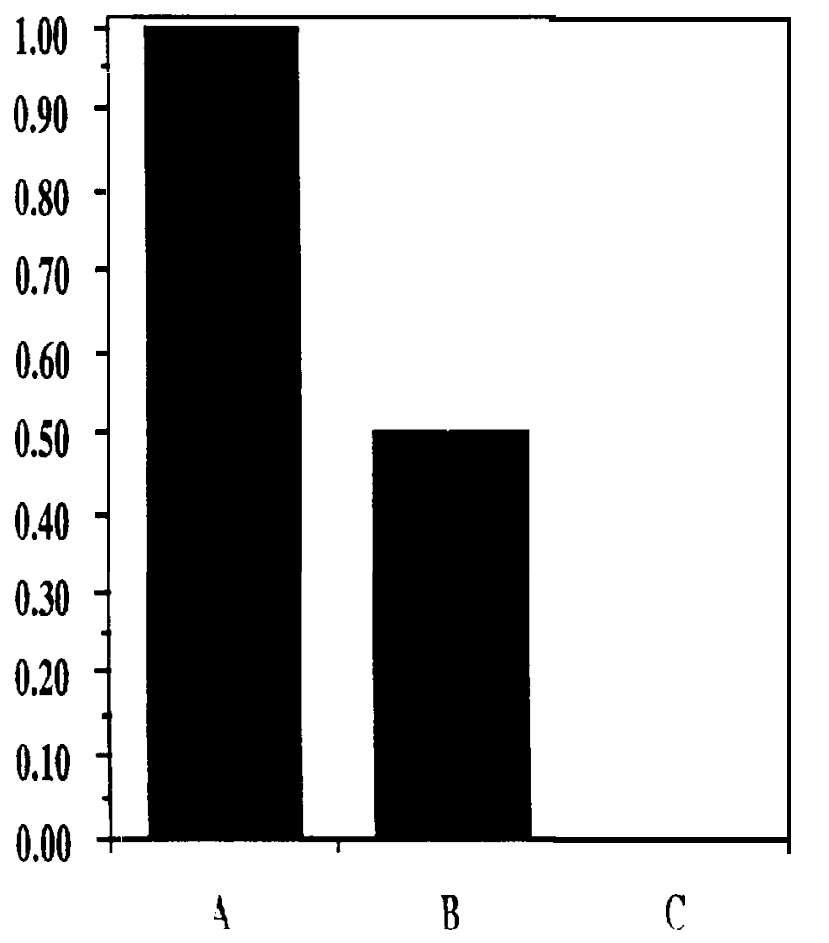

Based on the limiting factor concept, the HSI is equal to the lowest life requisite value obtained for either food or water.

Winter food $=\frac{a+b}{1.5}$

Where $a=$ woody vegetation value within $100 \mathrm{~m}(328 \mathrm{ft}$.) from the waters edge. The equation for determining this is:

$\left[\left(V_{1} \times V_{2}\right) \times V,\right]+\left[\left(V_{3} X V_{4}\right) \times V_{3}\right]$

and $b=$ woody vegetation value within $100 \mathrm{~m}$ $(328 \mathrm{ft}$.) to $200 \mathrm{~m}(656 \mathrm{ft}$.) from the waters edge. The equation for this is :

$$
\begin{aligned}
& .5\left[\left(V_{1} \times V_{2}\right) \times V_{3}\right]+\left[\left(V_{3} \times V_{4}\right) \times V_{3}\right]
\end{aligned}
$$

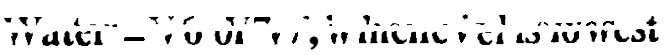




\section{LITERATURE CITED}

Allen, A.W. 1982. Habitat Suitability Index Models: Beaver, Biological Report No. 82-10. 30. Western Energy Land Use Team, Fish and Wildlife Service, Ft. Collins, CO.

Ashely, P. undated. Habitat Suitability Index Model: Columbian Sharp-tailed Grouse. Unpublished report on file Washington Dept. of Wildlife, Spokane, WA.

Jageman, H. 1984. White-tailed Deer Habitat Management

Guidelines. Bulletin No. 37 Forest, Wildlife, Range

Experimental Station, Univ. of Idaho, Moscow.

Kaumheimer, D. personal comm.

Prose, B.L., 1987. Habitat Suitability Index Models: Plains Sharptailed Grouse, Biological Report No. 82-10.142 National Ecology Center, Fish and Wildlife Service, Washington D.C.

Roberts, H.B., 1956. Food Habits and Reproductivity of White-tailed Deer in the Hatter Creek Enclosure. M.S. Thesis Univ. of Idaho, Moscow.

\section{ACKNOWLEDGEMENTS}

We wish to thank Paul Ashely, Dept. of Wildlife, for his help in critiquing this manual. 
IN-STREAM HABITAT IMPROVEMENT PLAN FOR BLUE CREEK, STEVENS COUNTY, WASHINGTON

Prepared for:

Spokane Tribe of Indians

Wellpinit, Washington

Prepared by:

John P. Buchanan

Department of Geology

Eastern Washington University

Cheney, Washington 99004

March 1992 


\section{Table of Contents}

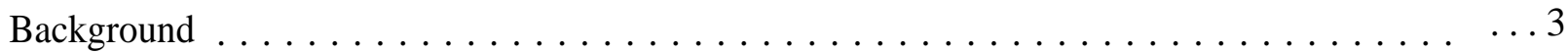

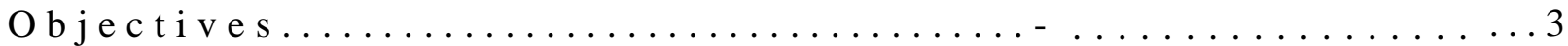

Location and Physiography of Study Area $\ldots \ldots \ldots \ldots \ldots \ldots \ldots \ldots \ldots$

General Considerations on Habitat Improvement $\ldots \ldots \ldots \ldots \ldots \ldots \ldots$

Dams

Suitability Guidelines $\ldots \ldots \ldots \ldots \ldots \ldots \ldots \ldots \ldots \ldots \ldots \ldots \ldots \ldots \ldots$

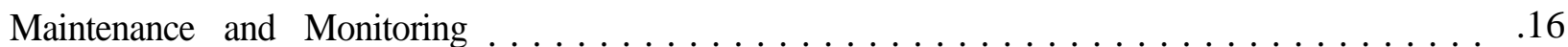

Beaver and Livestock Management $\ldots \ldots \ldots \ldots \ldots \ldots \ldots \ldots \ldots \ldots \ldots \ldots$

Conclusions/Recommendations $\ldots \ldots \ldots \ldots \ldots \ldots \ldots \ldots \ldots \ldots \ldots \ldots$

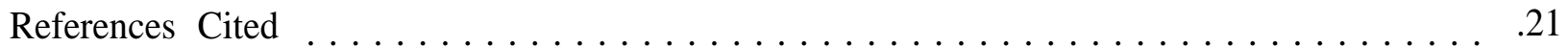




\section{Background}

Blue Creek on the Spokane Indian Reservation has already been the subject of much investigation, especially regarding its fishery (Scholz and others, 1988) and the downstream impact of contamination from the Midnight Mine drainage effluent in its headwaters (Nichols and Scholz, 1987; Plotnikoff and others, 1988). In addition, the upper part of the main channel was selected for detailed investigation by Buchanan and others (1991). This includes the length of the channel from its headwaters below Turtle Lake to just above the confluence of the main stem with Oyachen Creek; geomorphic maps prepared for the study reach are included in their report and describe in detail the physical characteristics of the creek.

Objectives

The objectives of this report ate four-fold and include:

1. evaluate all reaches of Blue Creek in order to determine which are most suitable for successful habitat enhancement and temediation,

2. recommend and design structures with the goal of promoting pool formation in the Blue Creek channel,

3. determine an implementation strategy for placement of in-stream structures, and make site-specific recommendations for placement of each structure, and,

4. recommend strategies for long-term maintenance and monitoring of in-stream structures. 


\section{Location and Physiography of Study Area}

Blue Creek is situated in northeastern Washington state in Stevens County and drains an area of approximately 21.5 square miles (Figure 1). Its most important tributary is Oyachen Creek. For purposes of discussion in this report, the "upper reach" of Blue Creek is considered that part of the main stem between Turtle Lake and the Oyachen Creek confluence. The "lower reach" is that part of the main stem between Oyachen Creek and the mouth of Blue Creek on Lake Roosevelt.

The Blue Creek basin is one of many small watersheds on the Spokane Indian Reservation that drain the Huckleberry Mountains to the south and southwest, and that debouch into Lake Roosevelt. The main stem of Blue Creek is about 6.5 river miles long and heads just west of Turtle Lake. From there it flows southwest toward its mouth located between river mile 12 and 13 on the Spokane River Arm of Lake Roosevelt.

The Blue Creek drainage basin ranges in relief from a high point on Wellpinit Mountain of 3464 feet above mean sea level to 1290 feet at its mouth on Lake Roosevelt. Blue Creek occupies an alluviated mountain valley and is for the most part a sand-bed alluvial stream. It is moderately sinuous in the alluvial reaches with gradients that average about 0.036 (about 190 feet/mile). Water discharge in the channel is very low during the summer months, and much of the lower reach of the main channel below the Oyachen Creek confluence experiences no flow during the summer months. Much of the riparian zone is densely vegetated by bushes and scrub beneath a variable coniferous canopy. 


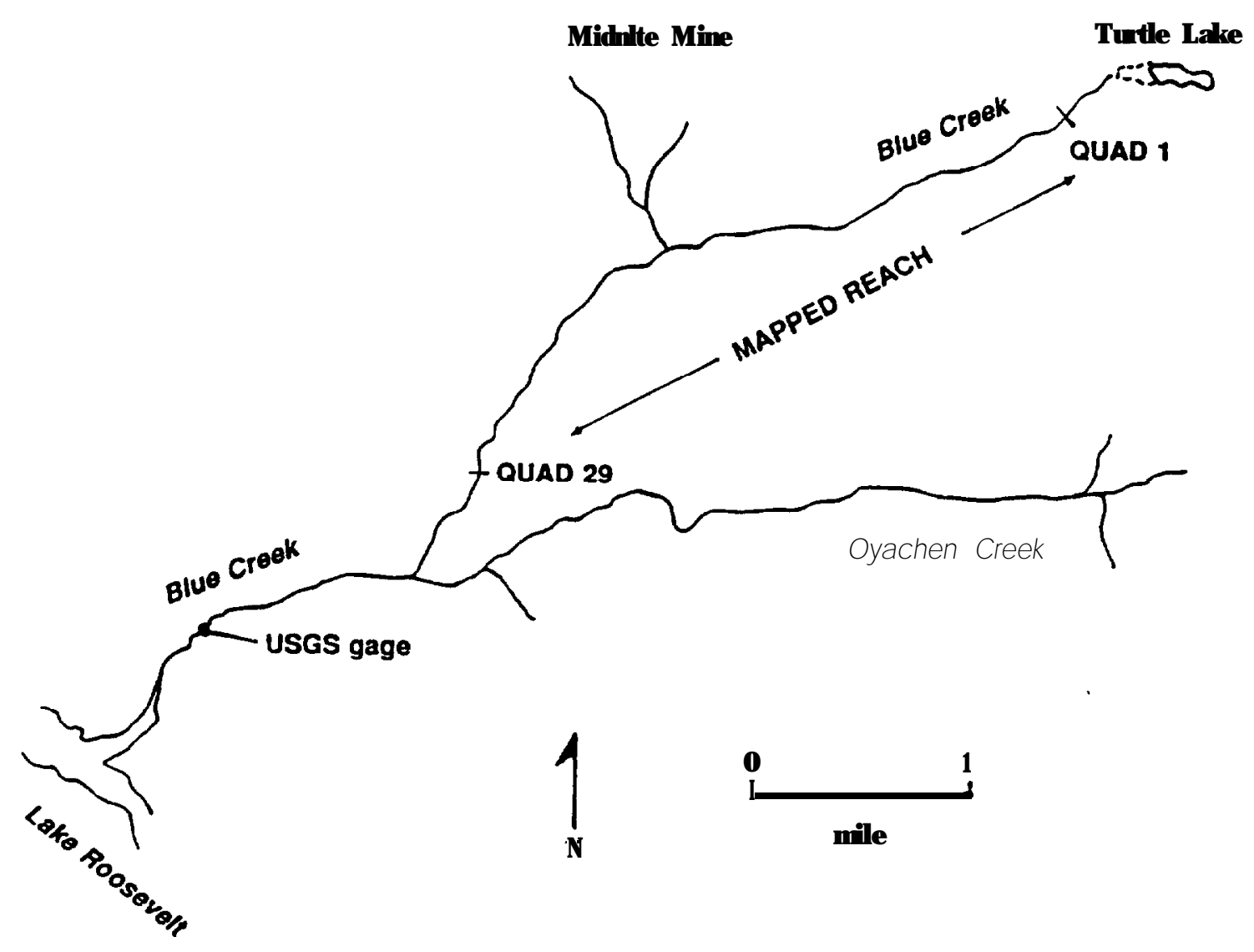

Figure 1. Map of the Blue Creek drainage on the Spokane Indian Reservation in northeastern Washington. Reach mapped by Buchanan and others (1991) is indicated. 


\section{General Considerations on Habitat Improvement}

The primary objective of this study is to evaluate Blue Creek in terms of what strategies may be best implemented in the channel to enhance the resident fishery and to promote use of the stream by wildlife. Successful strategies for stream improvement have been sought in the literature, and Gore (1985) and Hunter (1991) summarizes a variety of simple structures that have been employed in small stream restoration. Duff (1982) states that there is no need, however, for a great variety of structures for stream habitat reclamation, as there are really only a few things that may be done to a stream or river channel to make it more accommodating for fish and wildlife, and anyone with a little ingenuity can modify any one of a few simple designs to fit the

desired need. At present, the most commonly used in-channel treatments for fish habitat improvement are current deflectors, dams and weirs, bank covers, and boulder placements. Other less common treatments include trash catchers, pool excavation, channel blocks and beaver management.

However, caution is advised so that implementation of a stream restoration plan does not in itself cause additional destabilization of the channel. Should the structures fail, there is a good chance that they will create new problems that must be addressed in the future. In general, all in-stream structures must be of low profile to allow free passage of debris at high discharges. Should drifting logs catch on constructed devices in the stream channel the consequences could be disastrous as the device fails and the site becomes unstable, thereby accelerating erosion. Also, natural materials available on site are the desired construction materials, and their availability wiil keep project costs down. During construction, great care should be taken so that 
any impact on the channel bed and banks is kept to a minimum and to avoid conflict with spawning and incubation periods of salmonids. After construction, the stream banks around the devices should be protected, either naturally or with placement of additional materials to minimize bank erosion. Finally, any channel restoration project should anticipate future maintenance and monitoring. Debris may get caught and periodically need to be removed from devices, if not, this material may alter the hydraulics of the channel resulting in undesirable effects on the stream. Monitoring habitat and physical changes will allow analysis of what stream restoration strategies are most successful so that better decisions may be made before future projects ate implemented.

Since the primary goal in Blue Creek is to increase the amount of pool area in the channel, the following discussion will deal with structures designed exclusively with achieving that objective.

\section{Dams}

One of the most commonly used structures for habitat improvement is the low-profile dam, also referred to as a check dam, weir, plunge and over-pour. This structure is generally used to create or enhance habitat on small moderate to steep gradient headwater streams and are appropriate to implement on Blue Creek. The primary purpose of dams is to create pools of deeper water in shallow sections of the steam (Seehom, 1982). Dams can be relatively inexpensive, built from a variety of materials (most of which may be derived on site in the Blue Creek basin), and is proven successful in improving habitat (Wesche, 1985). Remember, dams can restrict trout migration if the structure is built too high. 
Dams have been utilized successfully butfailures have been reported in the past. Successful implementation has resulted in the following: pools 50 to 70 percent larger than natural pools, creation of habitat in a previously barren stream, increasing the amount of exposed spawning gravel, dams remaining intact after 35 years, and an increase in fish population of up to twenty times the original amount (Steffenud, 1982; Card, 1961; Rockett and Mueller, 1968; Claire, 1978; and Maughan and others, 1978). Many failures have also been reported which include: bank erosion, no increase in fish population, blockage of fish passage, dams lost due to washout during flooding, dams being buried or becoming nonfunctional (Rockett, 1979; Richard, 1963; Johnson, 1967; and Knox, 1982).

There are two primary factors to consider when installing dams - proper siting and proper construction. The following list of siting criteria (adopted and modified from Wesche, 1985) has been developed from past experiences cited in the literature:

Generally, low dams are successful on smaller (3 to 30 foot wide), high gradient (0.5 to 20 percent slope) headwater streams not susceptible to excessive flood flows (peaks from approximately 95 to 195 cubic feet per second) (see Raleigh and Duff, 1980; White and Brynildson, 1967; U.S. Forest Service, 1969; Wyoming Game and Fish Department, 1982a: Seehom, 1982).

Good location for placement of dams is in a straight, narrow reach at the lower end of a steep break in the gradient of the stream channel (Seehom, 1982).

The stream bed substrate should be stable at placement site.

The stream banks should be stable and well defined.

The site should allow the dam to be anchored well into the banks (at least three to six feet on each side).

Successive structures should be place no closer than five to seven channel widths apart (White and Brynildson, 1967). 
Sites with availability of natural construction materials can make a project much more economically feasible.

There are several different types of dams that have been designed and constructed over the years: rock-boulder dams, log dams and gabion dams. Because of the lack of boulder-size clasts in the Blue Creek channel, and because that gabion dams have had many reported problems, including difficulty in construction, expense, need for frequent repair and maintenance, and are unaesthetic, only dams constructed of logs are discussed in detail below.

Over the past 50 years, numerous designs (as many as ten) of log dams have been tested Log dams can be designed in several configurations depending upon the desired height and stability. The single log darn, stacked log dam, pyramid dam, K-dam (Figure 2), and wedge dams are suited to installation in Blue Creek, provided that the siting criteria above are adhered to, and the following general construction criteria are followed:

Anchoring the ends of the dam (or at least one end) is critical to its long term success. Log ends should be buried in the banks at least three to six feet if possible or at least one-third of the channel width. A rebar pin through one end and into the substrate is also useful in anchoring the log dam, and will allow the dam to swing should a flood event destabilize the site, thereby limiting the amount of bank erosion (Nelson and others, 1968; Alvarado, 1978; Claim, 1978).

Undercutting is the main reported cause of failure in log dams. To mitigate this risk imbed the base $\log$ at least 0.5 feet into the substrate. If the stream bed is soft and erodible and susceptible to scour, a mudsill over fabric tied to the upstream face of the log will add stability. Placement of cobbles and gravel along the upper edge is also beneficial (Duff, 1982).

Endcutting is the second mode of failure on log structures. Riprap should be place over the buried ends of the logs if possible.

The size of the logs used depends on stream size, availability at the site, desired height of the structure and availability and access of heavy equipment. Ten inch diameter logs should be the minimum size used especially in single-log dams so 

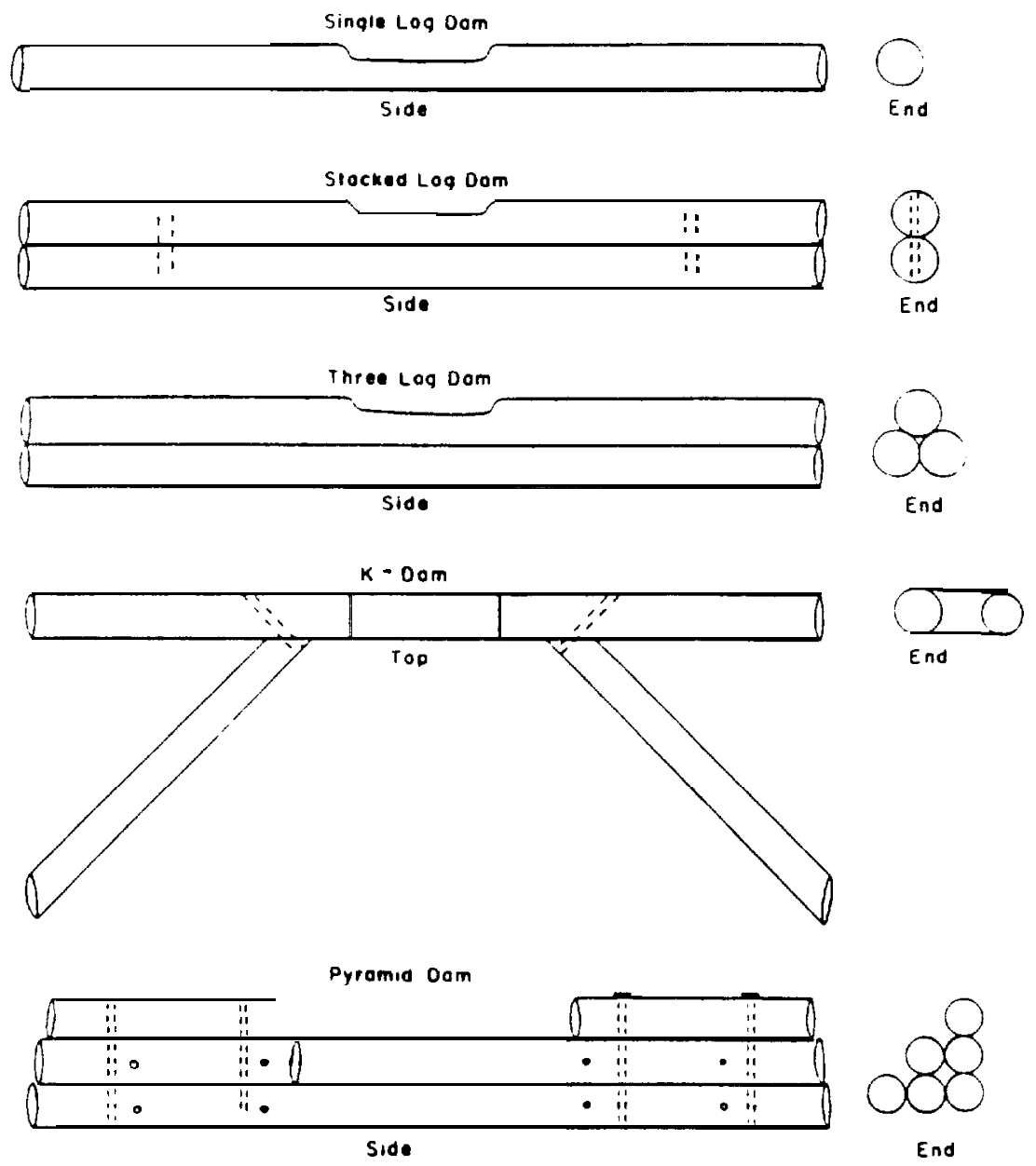

Figure 2. Diagram showing simple schematics of a variety of log dams (from Wesche, 1985). 
that a portion of it may be imbedded in the channel bed and still allow for a waterfall over the $\log$.

The key to longevity of the log structure is to keep water pouring over the entire length of the log dam, keeping it wet as much of the time as possible. A small amount of overflow along the entire log will prevent rot and decay, and life expectancies can he in the range of 20 to 40 years (Alvarado, 1978).

The simplest and easiest structure to construct is the single log dam (Figure 3). It is also proven to be the most effective and most utilized long structure. Generally it is used in small streams (less than 20 feet wide) when the creation of small pools is desired. The single log dam, because of its simplicity, can usually be installed in a matter of several hours in most cases, therefore, several structures may be constructed each day. Cost of the structure will be a function of location, labor, stream width, site characteristics and availability of logs. Should deeper pools be desired, the $\log$ s can be stacked and tied together with pins of rebar (Figure 2).

A mudsill must be applied to the upstream face of any dam to preclude leakage of the structure. Since in most cases the primary purpose of the dam is to raise the upstream water level and create a deeper pool, obtaining a good seal is the key to success of the darn. If the dam is constructed of stacked logs, the logs should be hewn smooth so that the lie flat against each other. In most cases, however, hogwire or other heavy wire, such as chain link fencing, can be stapled to the upstream side of the log structure and some type of construction fabric placed on top. This wire and fabric addition keeps material from washing underneath the structure and undermining it a higher flows.

A more stable variation of a single log dam is the K-dam (Figure 4), which derives its name from the configuration of the structure due to the addition of stabilizing downstream braces. It is somewhat more stable than the single log dam but requires more construction time because of 


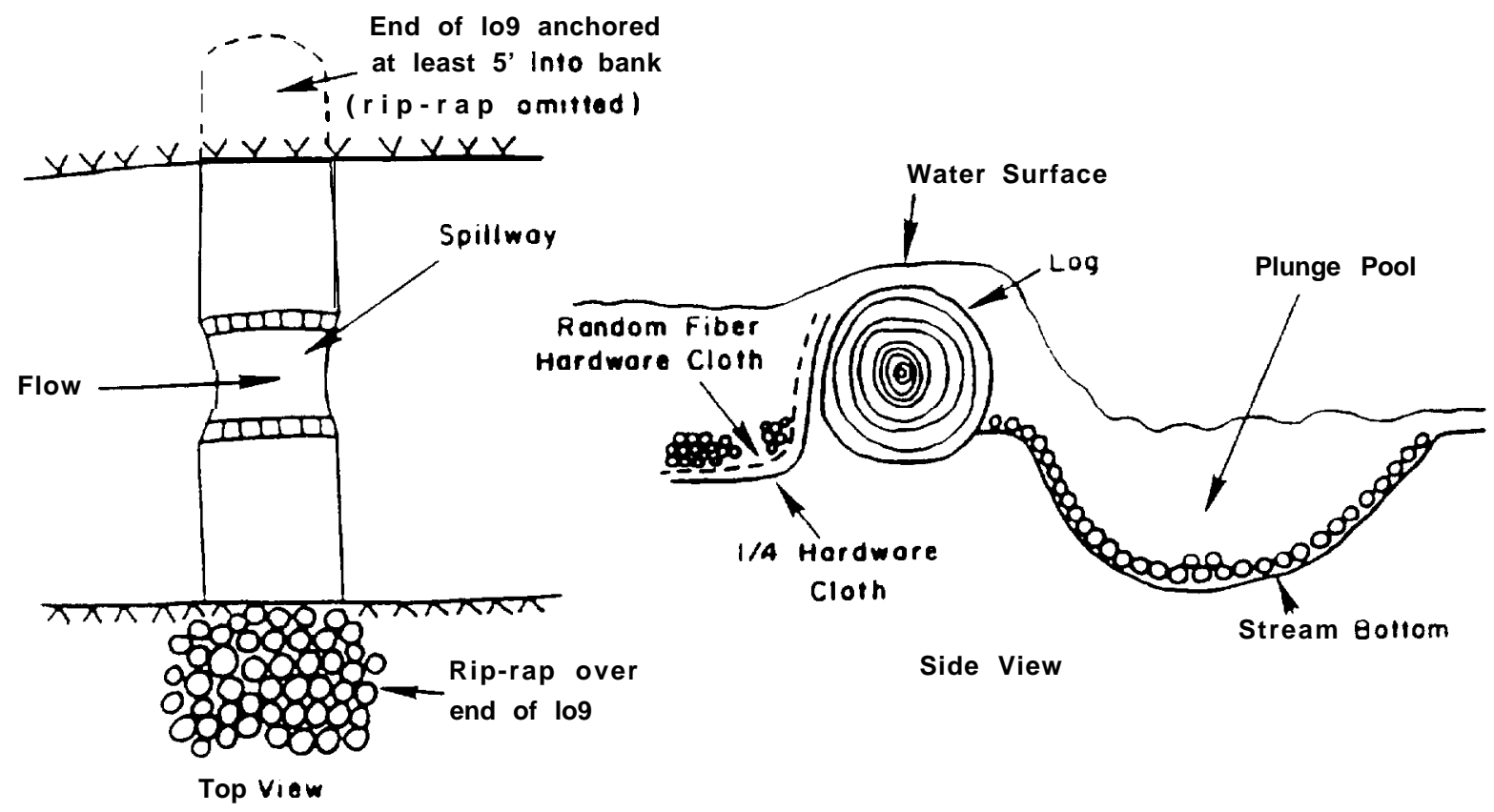

Figure 3. Construction detail of a single log dam (from Wesche, 1985). 


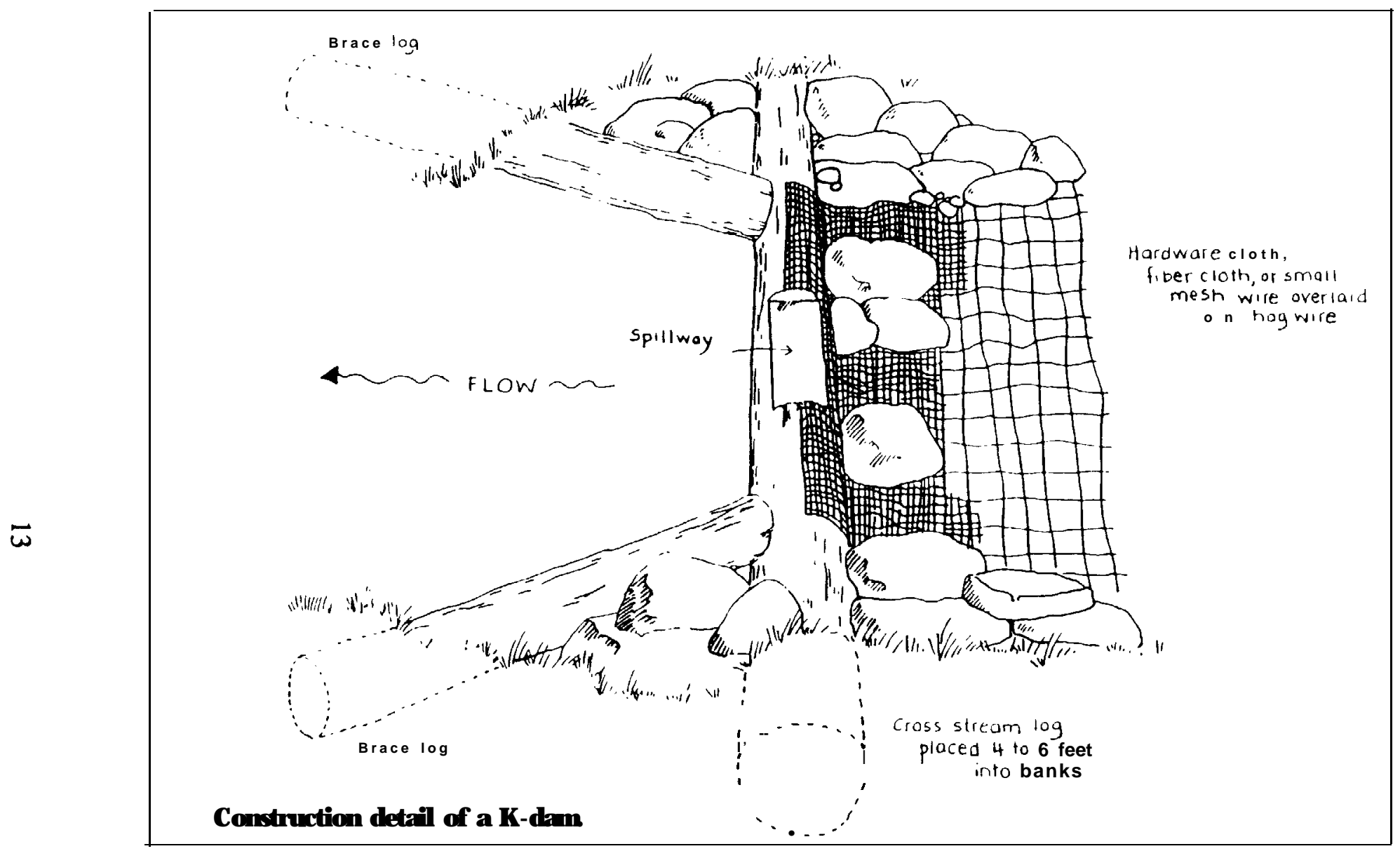

Figure 4. Construction detail of a K-dam (from Hunter, 1991). 
its increased complexity. One log can be used to span the entire stream width, with braces placed on the downstream side at about 45" angle to the main log. Placement of wire and fill is similar to that of the single log dam outlined above. Experienced crews may place one of these structures a day in a stream channel.

A variant on the K-dam is the wedge dam (Figure 5). Two main logs are placed in the channel at a $90^{\circ}$ angle to one another, with the apex facing upstream. Butts of the two main $\operatorname{logs}$ should extend into the banks at least three feet, with additional brace logs placed as diagrammed in Figure 5) to add stability to the device. A six-inch drop along the top of the main logs from the banks to their apex in the center of the channel is recommended (Seehom, 1982). This can be achieved by utilizing the natural taper of the logs or by digging a trench in the streambed. Placement of wire and fill is similar to that of the single log dam outlined above. Experienced crews may place one or two of these structures a day in small stream channels.

\section{Suitability Guidelines}

Rosgen (1985) developed a universal stream classification system based on the morphological criteria of channel gradient, width/depth ratio, sinuosity, channel materials, channel confinement, entrenchment, soil and landforms. Blue Creek can be categorized as a type A4 stream in Rosgen's (1985) scheme. This type of stream is characterized as a moderate gradient stream (4 to 10 percent slope) with a sinuosity between 1.2 and 1.4 , bed and banks are predominantly sand, gravel and some silts, and the valley sides are steeply sloped with fine textured SOils. Furthermore, Rosgen and Fittante (1986) present guidelines that evaluate the suitability of specific stream types in terms of which fish habitat improvement structures may prove the most 


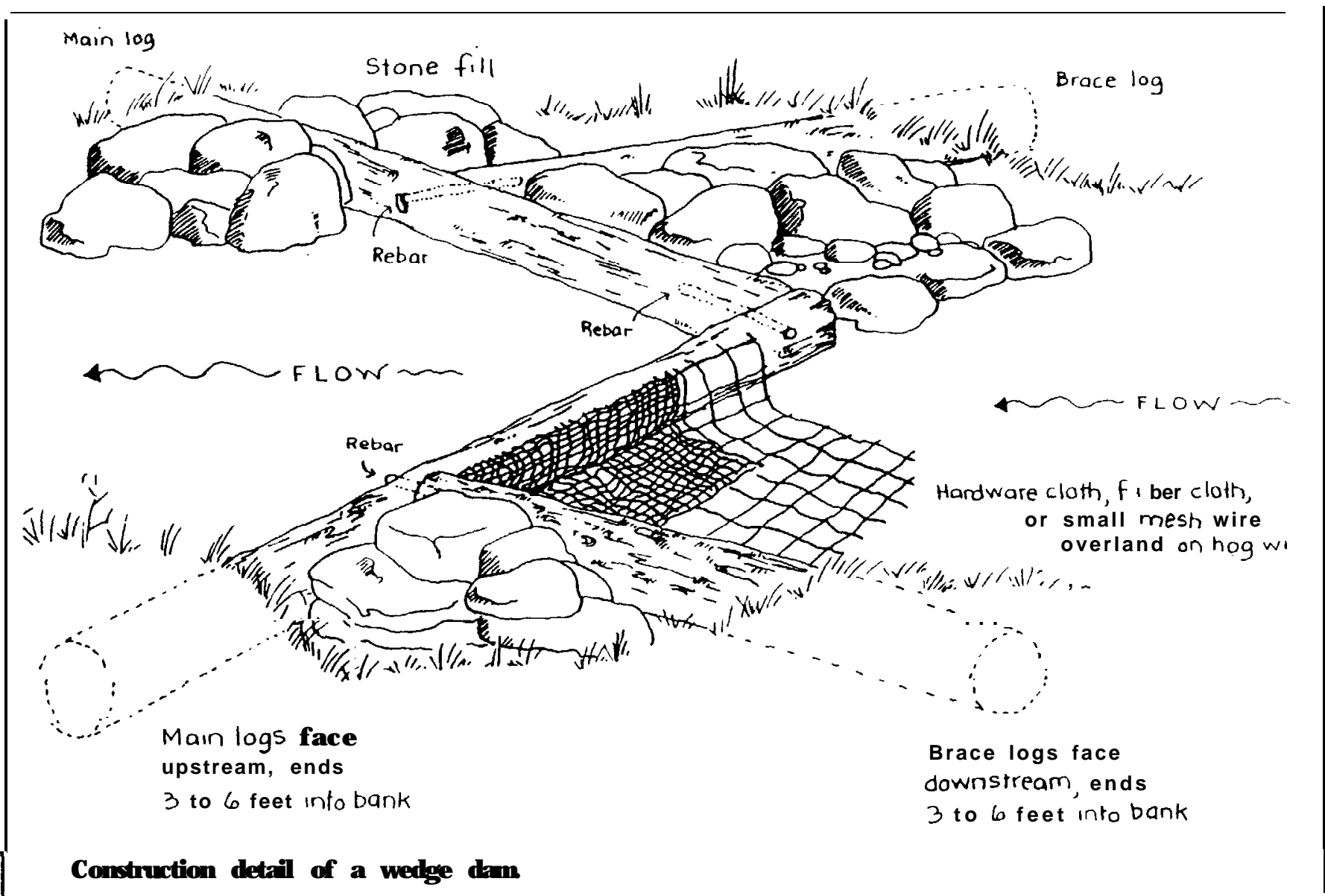

Figure 5. Construction detail of a wedge dam (from Hunter, 1991). 
appropriate and successful; this classification system is based largely on available literature and experiences in an attempt to correlate a wide variety of available structural designs to a wide range of stream types.

In the Rosgen and Fittante (1986) classification system, Blue Creek (a type A4 stream) is not explicitly assigned a suitability rating for any type of structure because this channel type has not been evaluated. However, for streams within the stream classification system most closely resembling Blue Creek, two suitability ratings can be determined with respect to the use of log dams. For the most part, the upper reach of Blue Creek (above the Oyachen Creek confluence) consists of stable bed and banks that define the channel and where bank stability is high. Low profile log dams receive a GOOD rating in this reach. Below the Oyachen Creek confluence, the lower reach is comprised of less cohesive bank materials thereby resulting in lower bank stability. Low profile log dams receive a FAIR to POOR rating for this reach, given the low bank stability and the propensity for the stream to laterally shift around these structures.

Figure 6 shows each of these reaches and their respective suitability ratings for low profile log structures.

\section{Maintenance and Monitoring}

No channel enhancement or restoration project should be implemented without thought to a long-term maintenance and monitoring program where physical and biological components of the system are reevaluated after a period of time. Maintenance of in-stream devices consists of periodically clearing debris caught in devices, attending to bank stabilization problems around devices, and perhaps removing devices that appear to be doing more damage than good. 


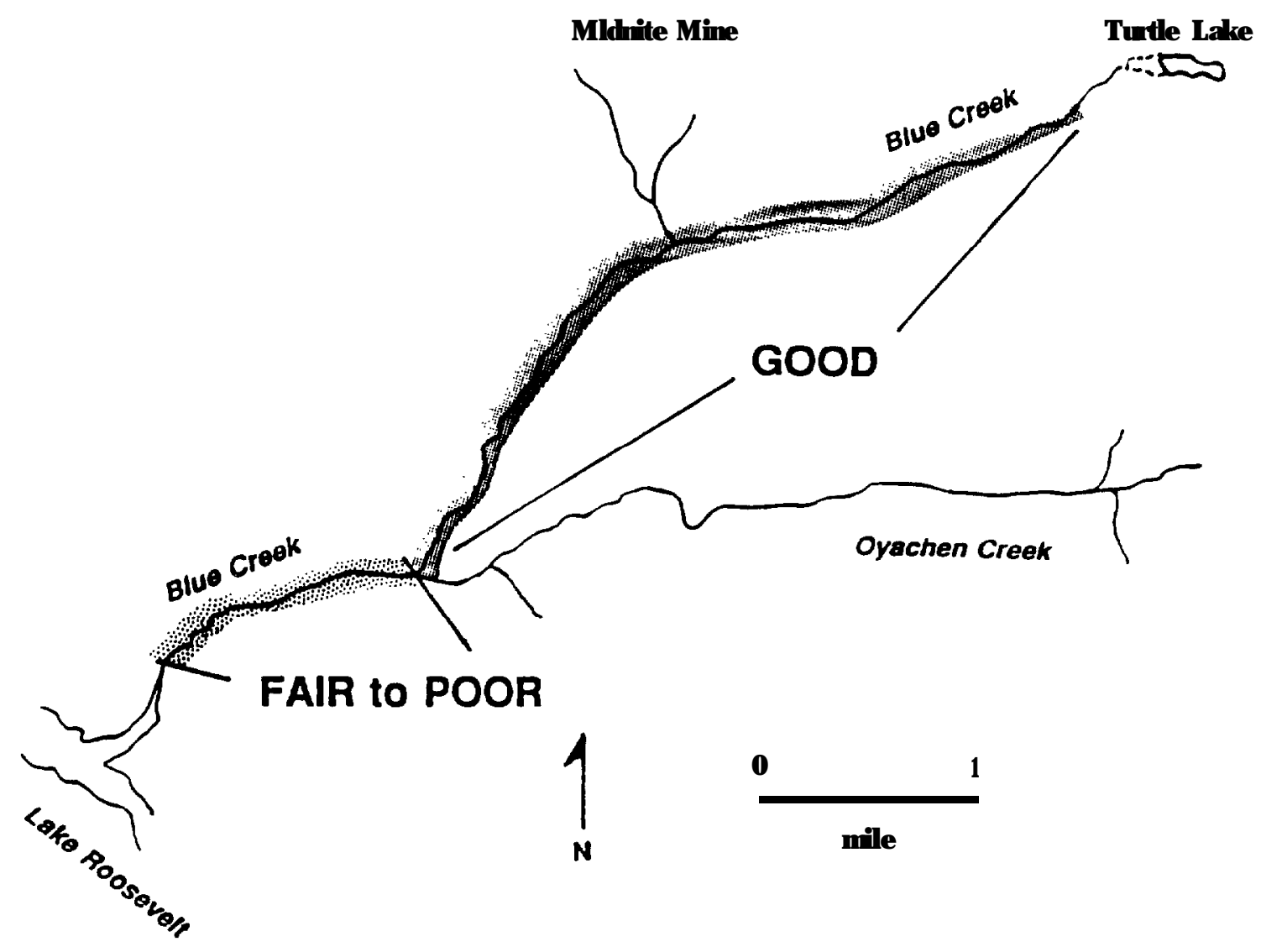

Figure 6. Map of Blue Creek showing suitability ratings for low profile log dams on specific reaches of the stream 
Monitoring activity can include remapping stream reaches in which restoration work was performed and compare the maps with baseline data before construction. On Blue Creek, the work by Buchanan and others (1991) serves as baseline work that outlines the physical characteristics of the upper reach before implementation of channel enhancement projects. During installation of the in-stream devices, photographs should be taken of each of the devices that show upstream, downstream and side views. In the future, similar photomonitoring and comparison of photographs taken through time will reveal clearly the success or failure of specific structures. In addition, a fish survey should be performed within three years of implementation of the channel restoration project to assess the success or failure of the structures in enhancing the fish population of Blue Creek. Work done by Scholz and others (1988) may serve as baseline data for the condition of the fishery on Blue Creek prior to implementation of the in-stream habitat improvement plan.

\section{Beaver and Livestock Management}

There is a significant beaver population in the upper part of the Blue Creek watershed as evidenced by the large dams and lodges present in the channel. Beavers should be recognized as a natural entity to the stream system, and that they build natural looking, and aesthetically pleasing, structures that produce results similar to low-profile log dams. One of the advantages of beaver dams is that there is no human labor involved in either construction or maintenance

of the structure. The disadvantage is that humans have little control on the site of placement of 
the dam, and in many cases this may destroy habitat as much as enhance the fishery. Therefore, select beaver dams should be removed, particularly those that preclude fish passage along the stream in the upper watershed.

Livestock graze in the watershed and has resulted in increased bank erosion at sites where the livestock is utilizing the stream for a source of water. A fencing program should be considered to mitigate this problem, allowing livestock access to the channel at select locations that will not allow introduction of sediment into the channel. Limiting livestock access to the stream may be an unpopular land use decision, however, this should not be sidestepped. Construction of devices in the channel to enhance the fish habitat will be futile unless other causes of stream degradation are mitigated at the same time.

\section{Conclusions/Recommendations}

It is feasible to construct a number of low profile log dams along the upper reach of Blue Creek that should enhance the fishery without destabilizing the alluvial channel. These log structures should be installed according to the siting criteria outlined above and constructed according to the instructions and diagrams provided earlier in this report. Similar structures may be placed in the lower reach of Blue Creek, however, careful placement is important as bed and bank stability of the creek in this reach are such that improper placement or construction could result in destabilization of the stream channel through time.

Should any structures be placed in the Blue Creek channel, a program of long term monitoring should be implemented immediately. Photographs should be taken of each structure 
for reference purposes, and each site revisited after the subsequent year runoff for inspection, maintenance and/or repair.

Control of livestock in the riparian zone of the channel should also accompany any in-stream strategies to enhance the fishery. Construction of devices in the channel to enhance the fish habitat will be futile unless other causes of stream degradation am mitigated at the same time. 


\section{References Cited}

Alvarado, R., 1978, Minimum Design Standards for Log Weirs: U.S. Forest Service Report, Pacific NW Region, Malheur National Forest.

Buchanan, J.P., Siegmund, B., and Gibson, B., 1991, Geomorphology of Blue Creek, Stevens County, Washington: Upper Columbia United Tribes Fisheries Center, Technical Report No. 27.

Claire, E., 1978, Rock work, log sills, bank stabilization, flow recovery, fencing, in Bender (ed.), Proceedings of the Fish Habitat Improvement Workshop, Ochoco Ranger Station, Oregon, September 26-27, 1978: Oregon Department of Fish and Wildlife, Salem, Oregon.

Duff, D.A., 1982, Historical perspective of stream habitat improvement in the Rocky Mountain area, in R. Wiley (ed.), Proceedings of the Rocky Mountain Stream Habitat Management Workshop, September 7-10, 1982, Wyoming Game and Fish Department, Laramie, Wyoming.

Gard, R., 1961, Creation of trout habitat by constructing small dams: Journal of Wildlife Management, v. 52, no. 4, p. 384-390.

Gore, J.A., 1985, The Restoration of Rivers and Streams, Theories and Experience: Butterworth Publishers, Boston.

Hunter, C.J., 1991, Better Trout Habitat - A Guide to Stream Restoration and Management: Island Press, Washington D.C.

Johnson, R.L., 1967, Evaluation of Stream Improvement Structures: Job completion report on project F-5-R-16, Montana Fish and Game, Helena.

Knox, R.F., 1982, Stream habitat improvement in Colorado, in R. Wiley (ed.): Proceedings of the Rocky Mountain Stream Habitat Management Workshop, September 7-10, 1982, Wyoming Game and Fish Department, Laramie, Wyoming.

Maughan, O.E., K.L. Nelson, and J.J. Ney, 1978, Evaluation of Stream Improvement Practices in Southeastern Streams: Bulletin 15, Virginia Polytechnic Institute and State University, Blacksburg.

Nelson, R.W., G.C. Horak, and J.E. Olson, 1978, Western Reservoir and Stream Habitat Improvements Handbook: USDI FWS/OBS-78/56, Western Energy and Land Use Team, Fort Collins, Colorado.

Nichols, D.G. and Scholz, A.T., 1987, Blue Creek metals analysis: concentrations of Al, Cd, Mn, $\mathrm{U}$ and $\mathrm{Zn}$ in whole eviscerated fish, fish livers, invertebrates and water: Upper Columbia United Tribes Fisheries Center, Technical Report No. 9, 106 p. 
Plotnikoff, R.W., Lang, B.Z. and Scholz, A.T., 1988, The effect of acid mine drainage on the aquatic macroinvertebrate community of Blue Creek, Spokane Indian Reservation, Washington: 8Upper Columbia United Tribes Fisheries Center, Technical Report No. 7.

Raleigh, R.F. and Duff, D.A., 1980, Trout stream habitat improvement - ecology and management, in Ring, W. (ed), Proceedings of Wild Trout Symposium II.

Richard, J.B., 1963, Log stream improvement devices and their effects upon the fish population, South Fork Mokelumne River, Calaveras County: California Department of Fish and Game, Inland Fisheries Administrative Report No. 63-7.

Rockett, L.C., 1979, The Influence of Habitat Improvement Structures on the Fish Population and Physical Characteristics of Blacktail Creek, Crook County, Wyoming: Report on project 3079 08-7601, Wyoming Game and Fish Department, Cheyenne.

Rockett, L.C., and J.W. Mueller, 1968, Stream Improvement Evaluations as Rlated to Fish Populations in Bear Trap Creek, Johnson County: Administrative Report on Project 0367-086602, Wyoming Game and Fish Department, Cheyenne.

Rosgen, D., 1985, A stream classification system: North American Riparian Conference, Tucson, Arizona.

Rosgen, D. and Fittante, B.L., 1986, Fish habitat structures - a selection guide using stream classification, in Proceedings of the Northeastern Trout Stream Improvement Workshop, Lock Haven, Pennsylvania, August 11-14, 1986.

Scholz, A.T., Peone, T., Uehara, J.1, Geist, D., and Barber, M., 1988, Rainbow trout population estimates in Blue Creek, Spokane Indian Reservation from 1985 to 1987: Detecting impacts of uranium mine discharge on the rainbow trout population: Upper Columbia United Tribes Fisheries Center, Technical Report No. 10, 47 p.

Seehom, M.E., 1982, Trout stream improvements commonly used on southeastern National Forests, in R. Wiley (ed.), Proceedings of the Rocky Mountain Stream Habitat Management Workshop, September 7-10, 1982, Wyoming Game and Fish Department, Laramie, Wyoming.

U.S. Forest Service, 1969, Wildlife Habitat Improvement Handbook: FSH 2609.11, Washington, D.C., U.S. Government Printing Office.

Wesche, T.A., 1985, Stream channel modifications and reclamation structures to enhance fish habitat, in Gore, J.A., 1985, The Restoration of Rivers and Streams, Theories and Experience: Butter-worth Publishers, Boston. 
White, R.J. and Brynildson, O.M., 1967, Guidelines for Management of Trout Stream Habitat in Wisconsin: Technical Bulletin No. 39, Wisconsin Department of Natural Resources, Madison.

Wyoming Game and Fish Department, 1982, Structures used in Wyoming, in R. Wiley (ed.), Proceedings of the Rocky Mountain Stream Habitat Management Workshop, September 7-10, 1982, Wyoming Game and Fish Department, Laramie, Wyoming. 